

Escuela Superior de

Administración Pública



Jesús María Molina 



\title{
Desarrollos y Tendencias \\ Contemporáneas de la Administración Pública
}

\author{
Jesús María Molina
}

Docente de Carrera e Investigador ESAP

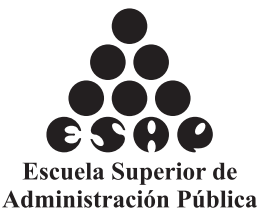




\title{
Desarrollos y Tendencias Contemporáneas de la Administración Pública
}

\author{
Autor: Jesús María Molina
}

Primera edición 2017

ISBN 978-958-652-438-4

Catalogación en la publicación - Biblioteca Luis Oswaldo Beltrán Jara - ESAP

Molina Giraldo Jesús María

Desarrollos y tendencias contemporáneas de la Administración pública / Jesús María

Molina Giraldo. - Bogotá : Escuela Superior de Administración Pública-ESAP, 2017.

132 páginas.

Incluye bibliografia

ISBN 978-958-652-438-4

1. Administración Pública--Enseñanza 2. Democratización-Administración Pública

3. Tecnología de la información--Administración pública 4. Administración

Pública- innovación 5. Posconflicto--Aspecto económico--Colombia 6. Modernización de la administración Pública. -- tít.

CDD-21: 351

\section{ESCUELA SUPERIOR DE ADMINISTRACIÓN PÚBLICA}

Claudia Marcela Franco Domínguez, Directora Nacional (E)

Fernando Augusto Medina Gutiérrez, Subdirector Académico

Alexander Cruz Martínez, Subdirector (E) Proyección Institucional

Oswaldo Bernal Sánchez, Subdirector de Alto Gobierno

Adriana Patricia Gómez Moreno, Secretaria general (E)

Claudia Marisol Moreno Ojeda, Decana Facultad de Investigaciones

Claudia Inés Ramírez Méndez, Decana Facultad de Posgrados

Coordinación editorial, Facultad de Investigaciones y Grupo de Publicaciones

Diseño de cubierta: Julio César Cárdenas Rozo

Fotografía de cubierta: Nelson Hernández Chitiva

Diagramación: Claudia Rangel Rodríguez

Bogotá D.C., 5 de octubre de 2017

Todos los derechos reservados. Esta obra no puede ser reproducida sin el permiso escrito de la Escuela Superior de Administración Pública. La responsabilidad de las opiniones expresadas en este documento compete exclusivamente a sus autores y no compromete de modo alguno, el pensamiento oficial de la Escuela Superior de Administración Pública, salvo en aquellos casos en que expresamente así se indique. 


\section{ÍNDICE}

\section{Desarrollos y Tendencias \\ Contemporáneas de la Administración Pública}

INTRODUCCIÓN

I. LA ADMINISTRACIÓN PÚBLICA COMO DISCIPLINA Y CAMPO DE ESTUDIO

Antecedentes históricos

La consolidación de la disciplina y su diversificación en el siglo XX

¿Qué puede ser estudiado en el campo disciplinar de la Administración Pública?

Comentarios finales.

II. DEMOCRATIZACIÓN DE LA ADMINISTRACIÓN PÚBLICA 45

La problematización de la administración pública desde la democracia $\quad 45$

Del modelo burocrático a la administración democrática 47

La democratización de la administración pública en América Latina 50

Comentarios finales

III. LAS TECNOLOGÍAS DE LA INFORMACIÓN Y DE LA COMUNICACIÓN APLICADAS AL SECTOR PÚBLICO

Situación de las TIC en el sector público

El gobierno electrónico

Organizaciones públicas y TIC

El aprendizaje y enseñanza de las TIC

66

Comentarios finales 
IV. LA INNOVACIÓN COMO CAMPO EMERGENTE EN LA ADMINISTRACIÓN PÚBLICA

La definición y la emergencia de un campo de estudio 73

La innovación: sus desafíos y aportes $\quad 75$

Innovación y reforma del Estado $\quad 77$

Los campos de innovación desde las Reformas del Estado 80

$\begin{array}{ll}\text { Comentarios finales } & 81\end{array}$

V. ADMINISTRACIÓN PÚBLICA DIVERSA Y MULTICULTURAL 85

Orígenes y avances de la administración pública diversa y multicultural 85

¿Qué es y cómo se define la administración pública diversa y 87 multicultural?

El conflicto por el reconocimiento y la igualdad 90

Comentarios finales 93

VI. POSCONFLICTO, ESTATALIDAD Y ADMINISTRACIÓN PÚBLICA

97

Elementos generales acerca del postconflicto $\quad 97$

La legitimidad como dimensión esencial en el postconflicto 99

La seguridad como soporte del postconflicto 101

La reconstrucción de la administración pública y la activación 104

económica

$\begin{array}{ll}\text { Comentarios finales } & 105\end{array}$

VII. CONCLUSIONES 109

A propósito de la democratización de la administración pública 110

A propósito de las TIC en el sector público 112

A propósito de la innovación en el sector público 115

A propósito de la diversidad y la multiculturalidad en la administración pública

A propósito del postconflicto y la reforma de la estatalidad 


\section{PRÓlogo}

\section{I}

El libro del Doctor Jesús María Molina, titulado Desarrollos y Tendencias Contemporáneas de la Administración Pública, será una obra muy bien recibida por motivo de su objeto y alcance. Se trata de un texto que se puede calificar de útil, temático y actual.

Su autor se desempeña como profesor de carrera de la Escuela Superior de Administración Publica de Colombia, donde realiza principalmente tareas docentes, de investigación y de difusión del saber administrativo. Estudió su pregrado cursando sendas carreras profesionales, una de ellas Administración Publica, la otra la de Historia. Asimismo, cursó estudios de maestría y doctorado en el campo de la ciencia política.

A los largo de 16 años de trabajo académico ha investigado e impartido cátedra sobre temas relativos a la democratización de la administración pública, la corrupción en el Estado, lo público y la participación ciudadana. El tema de la ciudadanía, pues, es uno de los objetos centrales del quehacer intelectual del Doctor Molina. En estas materias ha producido investigaciones que merecieron ser publicadas, entre las que destacan: "Reconstrucción de la Racionalidad Pública de la Administración Pública Estatal"; "Gestión Pública Democrática en Colombia. El Caso de los Ministerios", y "Democracia en Colombia y Poder Público ¿Es Público o Privado el Estado en Colombia”.

La naturaleza de los estudios profesionales y de posgrado del Doctor Jesús María Molina ha sido la base de su búsqueda de intersecciones y articulaciones entre la administración pública, la democracia y la ciudadanía. Asimismo, es un cruzado en favor de lo público, pues en sus trabajos es notorio un esfuerzo constante para construirlo y defenderlo, sin descontar la introducción de racionalidad pública mediante la presencia del poder ciudadano en el Estado.

\section{II}

La obra aquí prologada comprende temas contemporáneos de gran actualidad, junto con tópicos siempre presentes, como la administración pública como 
disciplina y campo de estudio, un ejercicio epistemológico necesario para emprender la impartición de la materia. Sin embargo, más allá, el lector encontrará la exploración a conciencia de temas de interés actual en el mundo, y particularmente en América Latina.

En efecto, el autor de la obra trata el sempiterno problema de la democratización de la administración pública,junto con el examen de una administración pública diversa y multicultural, así como una situación de posconflicto, estatalidad y administración pública. Estos temas, que están hondamente implicados en la vida política, se presentan hoy en días como materiales de estudio que derivan de situaciones de crisis universal. Después de los esquemas neogerenciales y clientelares, los especialistas ahora se abocan al replanteamiento de las relaciones entre la democracia y la administración pública, pasando por el análisis de la burocracia. Molina ha hecho una exploración profunda de la índole diversa y multicultural de la administración pública diversa, que ejemplifica singularmente con los casos de Bolivia y Ecuador, pero que se extienda a muchas naciones de América Latina. Aborda el caso de la población con capacidades diversas, y la situación de la mujer ante la administración pública. Un capítulo muy singular trata de la situación de sociedades luego de los conflictos, cuyo escenario reclama la restauración de los servicios públicos y la reincorporación de los antiguos combatientes a la vida civil.

El libro también comprende dos capítulos, digamos, más técnicos, donde se aborda las tecnologías de la información y de la comunicación aplicadas al sector público, y la innovación como campo emergente en la administración pública. El primer tema destaca la relevancia de del desenvolvimiento tecnológico para la administración pública, principalmente los trámites, mientras que el segundo nos recuerda que dicha administración debe avanzar al ritmo de la progresión del desarrollo y la tecnología.

\section{III}

Hay algunos pasajes muy significativos de la obra que merecen especial atención, por el sentido que encierran. En uno de ellos, el Profesor Molina recuerda que en su país y en la región latinoamericana hay contribuciones relevantes, como México, Argentina, Chile y Brasil. Sin embargo, falta camino por recorrer, porque allí, por exhaustivos y rigurosos que son, solo recogen un segmento de un ámbito mayor procedente de otros respecto al sector público. Antaño, sin embargo, el pensamiento administrativo latinoamericano parecía más original y crítico, como es visible en Florentino González, con su libro Elementos de Ciencia Administrativa. Molina, además, cita a un autor de apellidos Cerbeleón Pinzón, 
autor del texto Principios sobre la Administración Pública (1847). Hay que agregar que asimismo realiza una extensa exposición del pensamiento administrativo estadounidense en el siglo XX.

Molina participa en el desarrollo de nuestra disciplina, pues considera que la asunción de la administración pública como un campo de estudio no se clausura en la discusión sobre su estatuto científico. Enuncia una definición de la disciplina: "la administración pública se ocupa del estudio de fenómenos público-políticos articulados a través del Estado en acción en sus componentes de organizaciones públicas, de gobierno, de política pública, de dominación y de gestión, que no son comprensibles sin atender a los procesos desatados por el gobierno y el Estado en sus relaciones con la sociedad". En esta definición hay que destacar la distinción conceptual de lo público y lo político, y la recuperación del concepto "Estado en acción", una categoría muy preciada entre la mayoría de los autores clásicos como Charles-Jean Bonnin y Lorenz von Stein.

Este libro ha sido preparado en un tiempo dado, que podemos denominar “posneogerencial”. Dentro del texto, en la página 50, Molina realiza dos citas trascendentales. En la primera Robert Denhart señala que "los servidores públicos no prestan un servicio al cliente; ellos prestan democracia”; mientras que Terry Cooper dice que "un administrador público es un ciudadano que es empleado para trabajar a favor de nosotros; una especie de ciudadano profesional contratado para hacer el trabajo que en un complejo de gran escala como lo es la comunidad política somos incapaces de emprender por sí mismos". Hoy en día, pues, la administración pública está orientada al ciudadano, donde lo ha estado desde principio del siglo XIX como lo testificó Bonnin. Jesús María Molina es, entonces, un autor que destaca en este reverdecer de la administración pública basada en el ciudadano.

Pero hay más, pues el ciudadano no es un puro receptor de servicios públicos, sino un actor con iniciativa propia. Sin embargo, hay una resistencia a la participación ciudadana en la administración pública que, según Molina, no sólo proviene de las rigideces mentales del paradigma burocrático, sino también de la ausencia de innovación que reclama un trabajo de aprendizajes.Y, también, de "des-aprendizajes" de rutinas y métodos anclados en la inmovilidad. Se debe, pues, aprender a construir una "participación pública y/o participación ciudadana" tanto en las instituciones, como en la sociedad. Habría un camino abierto para una gestión pública democrática, a decir de Molina, que constituye una propuesta a favor de la "repolitización" democrática del Estado. De este modo, en la administración pública dejarían de imperar los criterios técnicos y 
económicos que soslayan propósitos sociales y políticos trascendentales. Sería, en fin, una estrategia para superar problemas de ineficiencia y deterioro de lo público por efecto del dominio del Estado por parte del clientelismo, la corrupción, el burocratismo y la tendencia al elitismo.

El capítulo relativo a las tecnologías de la información y de la comunicación (TIC), es sumamente ilustrativo. En sus páginas, la administración pública es presentada como una entidad propicia al desarrollo al poder adoptar las TIC en plenitud. El Profesor Molina presenta una batería de datos de enorme valor, para hacer un mapa del alcance de las TIC. En los primeros años del siglo XXI ya existían más de 50 mil páginas web de los gobiernos, toda vez que casi 100 páses tienen sitios de Internet mediante los cuales prestan servicios públicos. Particularmente, en el 2012, la Unión Europea alcanzó tasas del 32\% en gobierno electrónico, en tanto que la OCDE logró tasas hasta el 40\%. En fin, en 55 países se tramitaban documentos de identidad, certificados de nacimiento y licencias para manejo de automóviles. Otros muchos países daban vía abierta al pago de impuestos mediante mecanismos electrónicos.

De manera que uno de los campos donde destaca el uso de las TIC es el gobierno electrónico, también llamado E-Goverment. Con base en el enunciado de un autor de apellido Rhoda, Molina lo define de la siguiente manera: "por gobierno electrónico se ha entendido a los productos y a los procedimientos desplegados por los gobiernos para interactuar con sus destinatarios mediante el uso de las TIC, y que se pretenden, generen valor público".

Un capítulo muy interesante trata con la innovación, tema que el profesor Jesús Molina lo encuentra situado en la controversia conceptual. Unos autores la definen orientada a la investigación de nuevas soluciones a problemas existentes. Pero el autor de esta obra, con base en el pensamiento de D. Rondinelli, considera que una respuesta más completa señala que la innovación se refiere a los cambios en los cursos de acción de los gobiernos que alteran el statu quo, toda vez que plantean nuevos caminos para hacer mejor las cosas. De manera que el resultado principal de la innovación, consiste el "éxito", es decir, en la transformación de determinadas situaciones y en el cambio de rutinas y las culturas organizativas.

Un tema que debiera ser permanente en los estudios de la administración pública latinoamericana, es que su naturaleza diversa y multicultural.Y aunque este rasgo no le es privativo, si representa mucho de su esencia. Jesús María Molina plantea tres paradigmas al respecto: la discriminación, la legitimidad, 
y la efectividad, categorías de gran interés para la administración pública. El primero plantea la inclusión de minorías históricamente discriminadas, dentro de los marcos de la administración pública. El segundo paradigma se orienta a la calidad de los servicios públicos, pues la administración pública los prestará mejor si valora la diversidad y lo multicultural. El tercer paradigma apunta a la diversidad laboral, por cuanto mejora los procesos internos y los entornos organizacionales. Estas fórmulas dan espacio amplio para combatir los efectos nocivos de la discriminación, en todas sus formas, y ofrecen una visión innovada de la administración pública.

Finalmente, el profesor Molina nos ofrece una interpretación nítida de la necesidad de restablecer una administración pública, que ha padecido el efecto destructivo del conflicto. Es un campo del que debe ocuparse el posconflicto y que consiste en rehabilitar las administraciones públicas. Cita, pues, a D. Brinkerhoff, que apunta que "el conflicto y la guerra destruyen la infraestructura básica, interrumpe la prestación de servicios e impide rutinas asociadas con el diario vivir". Es decir, desestabiliza los procesos vitales de una sociedad. Este es un tema céntrico hoy en día. Molina señala que en la segunda mitad de siglo XX un tercio de los países del mundo habían tenido conflictos internos. En el 2009, por su parte, existieron 36 conflictos armados en 27 países. Para culminar exitosamente los procesos de posconflicto se debe atender desafios y escenarios centrales, entre los que destacan la legitimidad, la seguridad, la reconstrucción de la administración pública y la activación económica.

\section{IV}

Las notas precedentes no han tenido más motivo que estimular en el lector, la lectura de una obra que tanto ofrece a quienes deseen conocer el desarrollo y las tendencias contemporáneas de la administración pública.Tal es, precisamente, el título de una obra bien escrita y documentada por su autor,Jesús María Molina, que sin duda llamará la atención de los interesados en la administración pública.

En fin, debemos aplaudir el buen tino de la Escuela de Administración Pública al publicar esta obra y, al mismo tiempo, estimular el trabajo de investigación de sus profesores de carrera.

Omar Guerrero

Ciudad de México, verano de 2017 



\section{INTRODUCCIÓN}

La Administración Pública como saber es un campo fascinante y vital para el destino de las colectividades. Sus primeros pensadores en los siglos XVIII y XIX buscaron conseguir grandes propósitos a través suyo, relacionados éstos, con la mejora, el fortalecimiento y la felicidad de las sociedades. Aunque las visiones de dichos precursores pueden considerarse como ideológicas, no por ello erraban respecto a situar el importante papel cumplido por la acción administrativa en lo referente a intervenir y transformar las vidas de las personas. Desde sus primeros amagos, la Administración Pública como disciplina social se ocupó de estudiar la acción de las autoridades, los reglamentos y las burocracias en su papel de ordenar la población. Un interrogante central en su estudio, lo fue y lo es, el de cómo organizar y conducir a sociedades con escalas territoriales y poblacionales cada vez más extensas y complejas. Otro, lo fue y lo es, el de auscultar cómo se transforman las voluntades y directrices de los regímenes políticos en bienes y servicios para los ciudadanos.

La expresión coloquial "del dicho al hecho hay mucho trecho" permite expresar de manera metafórica ese mundo de asuntos de los cuales se ha ocupado el estudio de la Administración Pública. En ese sentido, se ha concentrado en investigar ese "trecho administrativo" que debe superarse para que la abstracta voluntad política de los regímenes democráticos se conviertan, o bien, en las obras, los bienes y los servicios efectivos que esperan sus ciudadanos, o bien, en las acciones y resultados que desean sus gobernantes. Lograr superar dicho "trecho", ha implicado en muchos casos, construir y desplegar aparatos administrativos diseminados por los territorios para llegar a miles o millones de personas. Ha supuesto también, coordinar cantidades ingentes de recursos, agentes y acciones.

El no haber prestado atención a ese "trecho administrativo" a nivel práctico y epistemológico ha significado para algunas sociedades que sus mejores idearios o sus más esperanzadores proyectos políticos terminaran por convertirse en promesas incumplidas, o aún peor, en burdos engaños. Las más anheladas conquistas políticas o los más acabados diseños democráticos 
de nada llegan a servir si sus idearios no se traducen por efecto de las administraciones públicas en iniciativas y acciones concretas que aseguren los derechos del conjunto de la población. Quedarse en el "decir político" sin pasar al "hacer administrativo" ha llevado a dichas sociedades a vivir crisis de apatía, desconfianza, y en casos extremos, hasta rebeliones. Precisamente, transmutar propósitos políticos en acciones y productos concretos que impacten la vida de la población, es el papel que le corresponde cumplir en los regímenes democráticos a las administraciones públicas y a los gobiernos que las orientan.

A pesar de su importancia, la administración pública como fenómeno institucional que actúa en las sociedades ha pasado casi que inadvertida para la opinión pública y el mundo académico ${ }^{1}$. No obstante, es fácil deducir que sin sus agentes, acciones y organizaciones dificilmente pueden operar y perdurar las democracias modernas. Por eso, se hace necesario su estudio, en particular, comprender cuáles son los desafíos que presenta en la actualidad. Entre ellos, se pueden mencionar varios. Uno, es que la administración pública actúe con celeridad, efectividad, equidad y transparencia respecto a las demandas y necesidades de los ciudadanos. Otro, reside en que pueda garantizar la incidencia y participación de los ciudadanos en sus decisiones, organizaciones, procesos y políticas. Uno más, está dado porque sus organizaciones y políticas públicas puedan quedar blindadas contra prácticas de corrupción y apropiaciones indebidas. Uno más, es que su mundo administrativo incluya y reconozca la diversidad de expresiones, culturas e identidades que atraviesan las sociedades.

Conforme a lo anterior, este texto se ocupará de lo siguiente:

Evidenciar de manera esquemática cómo desde el siglo XVIII hasta la actualidad se ha constituido la administración pública como un fenómeno histórico e institucional, al igual que, como una disciplina social y científica.

Exponer cómo han venido ganando terreno corrientes de pensamiento que apuestan a democratizar la administración pública sobre la base de centrarla en los ciudadanos, abrirla a su participación y servir a sus intereses.

1 Es bueno advertir que en el texto aparece el término administración pública unas veces en sus letras iniciales con minúscula y otras con mayúscula. Si aparece con minúsculas, el mismo refiere al campo fenoménico, fáctico o empírico de la acción o del aparato administrativo que interviene en la sociedad. Por su parte, si aparece con mayúsculas se hace para designar al saber o la disciplina científica que se ocupa de su estudio. 
Revelar cómo las Tecnologías de la Información y de la Comunicación (TIC) vienen convirtiéndose en realidades e instrumentos cada vez más importantes para los gobiernos y las administraciones públicas.

Caracterizar la innovación en el sector público como un campo de estudio que apuesta a generar respuestas novedosas y pertinentes a problemas presentados por los gobiernos y las administraciones públicas.

Evidenciar cómo en el sector público la diversidad y la multiculturalidad viene ganando terreno bajo el propósito de incluir, reconocer y nivelar grupos o sectores de la población tradicionalmente excluidos.

Realizar una aproximación interpretativa de las agendas, retos y transformaciones respecto a la estatalidad y la administración pública en contextos de postconflicto.

Las temáticas atrás enunciadas dan cuenta de una serie de desafíos y tendencias que vienen transformando a la administración pública como fenómeno institucional y como disciplina social. No obstante, hay otras temáticas que sin ser objeto de tratamiento aquí, también son importantes de investigar. A continuación se mencionan. Una, alude al campo de la ética en el sector público el cual remite a los dilemas que debe enfrentar el gobernante y el servidor público en su accionar cotidiano en lo que respecta a dejarse guiar por el interés público o privado; igualmente, refiere a las estrategias que pueden asumir los responsables públicos contra las prácticas y procesos de corrupción en el sector público (Cox, 2009), (Cooper, 2001), (Menzel, 2010), (Fukuyama, 2005) y (Transparency, 2005). Otra temática, refiere a la especificidad e importancia cobrada por las ciudades en el contexto actual, las cuales dadas sus problemáticas singulares, tienen estrategias e instrumentos cada vez más diferenciados de los utilizados por los órdenes nacional y local (Rojas, 2010), (World Bank, 2013) y (Mila, 2001). Una temática más, refiere a las distintas tradiciones, estilos y reformas que han asumido las administraciones públicas en los distintos países, de las cuáles si se quisiera, pueden extraerse aprendizajes (Peters, 2010), (Otenyo, 2006) y (Liou, 2001).

Los argumentos desarrollados en este libro se realizaron con base en una revisión extensa de literatura que hoy circula a nivel internacional. Como un aporte a la discusión que se viene adelantando en Colombia y en América Latina los trabajos fueron intencionalmente seleccionados de la lengua 
inglesa ${ }^{2}$. Es de mencionar que, en el país y en la región hay una limitación de editoriales que poco hacen por traducir al idioma castellano y publicar las últimas novedades que en otras latitudes vienen produciéndose respecto al campo en cuestión. No obstante, hay importantes contribuciones realizadas por autores procedentes de países como México, Argentina, Chile y Brasil, las cuales por exhaustivas y rigurosas que llegan a ser, sólo alcanzan a recoger un segmento limitado del espectro cada vez más amplio de visiones que desde distintos lugares del mundo vienen produciéndose en torno al sector público.

Este texto intenta construir un puente más entre lo producido en otras latitudes y lo discutido en los contextos propios. Gracias a las herramientas y posibilidades que hoy brinda la Internet y las TIC fue posible consultar universidades, escuelas de gobierno, instituciones oficiales, asociaciones de profesionales, comunidades académicas, tiendas virtuales y librerías de distintas partes del mundo. Esa búsqueda fue llevando a problematizar una consideración con que inició el estudio, a saber, que eran relativamente pocos los autores y trabajos académicos existentes en la actualidad respecto al sector público, más en particular, respecto a la Administración Pública como disciplina social.Avanzada la búsqueda, se pudo constatar que dicho supuesto se basaba más un prejuicio que en una realidad ya que lo hallado supero con creces lo esperado. Lo anterior generó una lección: lo referenciado en círculos locales, nacionales y regionales no debe ser el único rasero con el que se valore una disciplina, o así mismo, con el que se llegue a afirmar qué es ella y cuáles son sus avances.

Las reflexiones que integran este libro surgieron del propósito de levantar un estado del arte respecto a las últimas tendencias de la Administración Pública. Dicho trabajo encomendado en el año 2014 por la Escuela Superior de Administración Pública (ESAP) tenía por objetivo constituirse en uno de los diversos insumos intelectuales que servirían de soporte para tomar decisiones de hacia dónde debían orientarse sus planes de formación impartidos. Tras realizarse la tarea encomendada, se valoró que el considerable esfuerzo de búsqueda, revisión, clasificación, análisis y escritura de literatura internacional que soportó dicho trabajo podía servir a una comunidad más amplia de docentes, estudiantes, expertos e interesados en el tema. Consideración que tomó mayor peso al constatarse la escasez de

2 El primer capítulo es la excepción a la norma. Al centrarse en un intento de reconstruir históricamente los pensadores y perspectivas que convergieron en la construcción de la Administración Pública como disciplina científica, se basó en una revisión de autores clásicos ya traducidos al español o que originariamente escribían en dicho idioma. Un apartado del capítulo II, también lo hace, teniendo en cuenta que los autores referidos son latinoamericanos. 
textos académicos en Colombia respecto a los temas abordados, y más en general, respecto a la Administración Pública como disciplina.

Las temáticas tratadas en este escrito pueden situar al lector ante importantes palancas de transformación institucional y social. Ocuparse de ellas, podría evidenciar cómo dispositivos administrativos que promueven la participación ciudadana tienen la potencialidad de contrarrestar capturas del Estado y procesos de corrupción. Así mismo, podría revelar cómo el uso de la innovación y de las TIC contribuye a estructurar aparatos administrativos que responden con rapidez, eficacia, eficiencia y oportunidad a la demandas de la sociedad. Igualmente, podría poner de presente que construir gobiernos y administraciones públicas diversas y multiculturales contribuyen a corregir exclusiones, inequidades y discriminaciones sufridas históricamente por distintos grupos de la sociedad. Finalmente, podría evidenciar cómo sociedades sumergidas en conflictos armados cuentan con la posibilidad de encontrar soluciones a ellos sí se ocupan de ciertas agendas $\mathrm{y}$ transformaciones en lo que respecta a su institucionalidad estatal.

Como la escritura siempre tiene un lugar de creación, en calidad de autor de este texto, agradezco a la ESAP y a su comunidad académica por sembrar la semilla que le dio inicio a su creación. Igualmente, extiendo mi gratitud por las discusiones y bibliografias compartidas a docentes que nutrieron la construcción de algunos temas y argumentos; así mismo, a todo el equipo de trabajo editorial que con su apoyo permitieron esta publicación. Aunque inusual, tras significativos problemas de salud que viví, también ofrezco mis más profundos agradecimientos a ese poder espiritual nombrado por muchas culturas como Dios. Finalmente, extiendo todos mis agradecimientos a quienes lean este texto y a quienes lo compartan. 



\section{I \\ LA ADMINISTRACIÓN PÚBLICA COMO DISCIPLINA Y CAMPO DE ESTUDIO}

\section{Antecedentes históricos}

En su edificación la Administración Pública como ciencia o disciplina social moderna ha tenido un largo recorrido histórico. Las Ciencias de la Policía desarrolladas entre los siglos XV y XVIII, las cuales tenían por propósito estudiar el cómo asegurar el orden interno de los nacientes Estados Nacionales, pueden entenderse como aquellos saberes precursores de la Administración Pública (Malagón, 2003). El pensador Alemán Juan Enrique Von Justi (1756) en su texto titulado Elementos Generales de Policía, señaló que, la Ciencia de la Policía buscaba asegurar las fuerzas del Estado y la felicidad de quienes lo integraban a través de la puesta en marcha de los reglamentos(Von Justi, 1756). Consideraba Von Justi, que no debía confundirse dicha ciencia con otros saberes como la política ya que mientras esta tenía como fin "la seguridad de la República tanto por fuera como por dentro", ella por su parte, buscaba mejorar y fortalecer a la sociedad por la acción de las autoridades. A criterio del autor en cuestión, la confusión de las Ciencias de la Policía con otras disciplinas pasaba por el hecho de no existir tratados claros que dieran una idea justa y completa de ella como ciencia, y por lo mismo, su obra proponía remediar dicho vacío.

Bajo dicho propósito,Von Justi dirá, que su reflexión no apuntaba a ocuparse de temas específicos como solían hacerlo los manuales del manejo de las Cámaras, sino más bien, buscaba establecer principios generales que la llevaran a ser asumida como una ciencia. Por ese camino, de un compendio de consejos alrededor de temas concretos, como era la regla en su época, quería pasar a una ciencia que diera cuenta de los pilares o criterios universales que inauguraran cierto campo específico y diferenciado de la reflexión y actividad humana y social. Con ello, el pensador Alemán invitaba a considerar que entre las disciplinas sociales que estaban emergiendo en su tiempo, debía existir una cuyo objeto de reflexión debía centrarse en el ordenamiento de las sociedades a partir de la acción de las autoridades y sus leyes. 
Juan Enrique Von Justí aunque fue uno de los principales exponentes de las Ciencias de la Policía, no fue el único. Su obra se inscribía en un conjunto mayor de tratadistas que tenían por objetivo cultivar saberes que buscaban contribuir al conocimiento de la población y el territorio con el fin de incrementar las fuerzas de las monarquías absolutas, que dicho sea de paso, fueron las que sentaron los gérmenes históricos de los Estados Nación modernos. Con las Ciencias de la Policía se buscaba entre otros propósitos, conocer el número de habitantes, sus ocupaciones, sus intercambios, sus recursos y sus necesidades. A la par, también se buscaba encontrar fórmulas de actuación gubernamental de cómo debían ser intervenidos dichos elementos para apalancar mayores recursos a favor de las autoridades e instituciones estatales de la época. Una función más tenían las Ciencias en cuestión, al buscar presentar y hacer ver ante la población las intervenciones de dichas autoridades como si se trataran de medidas encaminadas a lograr la felicidad y el bienestar de los súbditos.

Como su nombre lo indica, las Ciencias en cuestión tenían por objeto de reflexión el estudio de la Policía. No obstante, cabe aclarar que entre los siglos XV al XVIII dicho término servía para designar cuestiones diferentes a las que bajo la actualidad se nombran. Antes que a cuerpos de seguridad que velan porque se respeten las normas legales y se asegure la vida y bienes de los ciudadanos, más bien, para aquel momento histórico, servía para referir a los arreglos administrativos y de gobierno que eran instaurados para lograr la conservación del orden interior y el funcionamiento de la comunidad bajo el fin último de aumentar los poderes de las monarquías absolutas. Para Michell Foucault, la Policía como concepción y practica de una época, apuntaba al control y cobertura de las actividades de los hombres, en la medida que estas pueden constituir un elemento diferencial en el desarrollo de las fuerzas del Estado (Foucault, 2005, p.370).

Dicho control y cobertura, paulatinamente se fue institucionalizando en Europa en la creación estatal de unidades de gobierno y administrativas referidas a la defensa, la justicia, los caminos, el comercio, la política etc. Para hacer factible la operación de dichas unidades, a las mismas se les conformó con un conjunto de personas las cuales tenían por función realizar y vigilar el cumplimiento de las tareas asignadas por el monarca o sus delegados. A dichas unidades le acompañaron también otras por aquel tiempo creadas que tenían por función el manejo de los recursos financieros de los reinados o principados: las Cámaras. Articulados a dichas unidades, se encuentran los 
saberes ya comentados de las Ciencias de la Policía, pero también, uno hasta ahora no mencionado, como lo fue el de la Cameralística ${ }^{3}$.

En retrospectiva histórica, la Policía como forma de organización de gobierno y administrativa para el control del territorio y de la población, en unión con las Cámaras, serían los orígenes institucionales de lo que hoy se conoce como el aparato administrativo moderno o la administración pública estatal. A ese fenómeno institucional e histórico le acompañaron y alimentaron las Ciencias de la Policía las cuáles serán a su turno, las precursoras en occidente moderno de lo que hoy se conoce como la disciplina social y científica de la Administración Pública. Lo atrás señalado, significa que la administración pública como fenómeno histórico, y la Administración Publica como disciplina y/o ciencia social, tienen una larga tradición histórica que remonta al menos a cinco siglos atrás, lo anterior, si se tiene en cuenta que se estima que dichas instituciones y saberes ya habían tomado forma en el siglo XV.

Medio siglo después de la obra de Von Justi, en otro lugar de Europa, Charles Bonnin (1808) desarrolló una reflexión con propósitos similares a los del pensador Alemán. En su trabajo titulado Compendio de los Principios de Administración arguyó dicho autor que con el mismo buscaba establecer los fundamentos y las leyes generales que permitieran instaurar la Ciencia Administrativa (Bonnin, 1834). A su entender, dicha ciencia tenía como objeto de estudio los principios que guían las relaciones sociales sostenidas entre individuos y comunidad, al igual que, los medios para conservarlas en el marco del interés común. Por ello afirmará que:

(...) la Ciencia Administrativa es la ciencia de las relaciones entre la comunidad y sus individuos, $y$ de los medios de conservación de estas mismas relaciones por la acción de las leyes y los magistrados sobre las personas y propiedades, en todo lo que interesa al orden social. La ciencia administrativa, pues, debe ser considerada como conocimiento de los principios de las relaciones sociales, es decir, análisis de las propiedades y fenómenos de estas relaciones, y como aplicación a las personas y cosas de las reglas mínimas que encaminan dichas relaciones al interés común (Bonnin, 1834, p. 36).

Para realizar su caracterización de la Ciencia Administrativa, Bonnin parte del supuesto de que el hombre posee una "sociabilidad natural" que liga a los seres humanos unos con otros. Por tal razón, considera que deben establecerse mecanismos que garanticen la conservación de dichas relaciones sociales. Es a la administración a la que le corresponde hacerlo, y

3 Definida de manera puntual, la cameralística tuvo por objeto el manejo de las finanzas de los monarcas y las de sus jurisdicciones territoriales. 
para lograrlo, debe garantizar la ejecución de las leyes teniendo como norte de actuación la armonización del interés público con el interés privado. Acorde a Bonnin, es sólo por medio del funcionariado y las estructuras de jerarquía y de autoridad que es posible lograr mantener el orden, ejecutar las leyes y poner en acción los reglamentos. La administración debe actuar en consonancia con el gobierno, el cual es definido por Bonnin como aquel que le corresponde dar el impulso necesario para que se haga realidad la voluntad del cuerpo político, mientras por su parte, a la administración le concierne recibir dicho impulso para comunicarlo a los asociados(Bonnin, 1834, p.319).

Para Bonnin, la administración es ciencia en tanto se refiere a la teoría de los principios productores de lo específicamente administrativo. No obstante, este corpus teórico necesita una práctica y un objeto de aplicación. En este sentido, ella aparece también como un arte que tiene por objeto ligar todos los componentes del Estado para convertirlo en un cuerpo político coherente y con unidad social. Dicho arte, lleva a la administración pública obrar directamente sobre el conjunto de asociados ejecutando las decisiones tomadas por la esfera gubernamental. Cuando se convierte en aplicación, ella entra a hablar de términos tales como ministros, concejos, división territorial, marcha gradual de la acción, relaciones públicas administrativas, policía administrativa, entre otros.

Es importante señalar que los planteamientos de Charles Bonnin aunque son afines con los de Juan Enrique Von Justi en cuanto al propósito de instaurar una ciencia de la acción del Estado sobre la sociedad, los mismos, terminan por inscribirse y anunciar una época distinta. Esta otra época de Bonnin, que coincide con el último cuarto del siglo XVIII y todo lo largo de los siglos XIX y XX, corresponde a la génesis y desarrollo de las sociedades industriales. En esta otra época, ya no se trataba que la organización política del Estado tuviera por función central acrecentar el poder de los monarcas y sus reinados, sino más bien, que impulsara el orden mercantil capitalista en una escala nacional e internacional sobre la base de apalancar el desarrollo de industrias, fábricas y relaciones laborales asalariadas, a la par que, la producción y el intercambio de mercancías. Para lograrlo, uno de sus pivotes centrales fue el de instaurar una clara demarcación legal e institucional entre lo público y lo privado, donde el primero de los términos estaría encarnado institucionalmente en el Estado que debía asegurar los intereses, esferas de acción, propiedades y derechos de los diferentes sectores que integraban la clase burguesa en ascenso, que dicho sea de paso, constituía el segundo de los términos -lo privado-. 
En búsqueda de lo anterior, el Estado y su aparato administrativo entró a conformarse no sólo como Estado Nacional sino también como Estado Liberal de Derecho. Bajo esta forma histórica el Estado se entró a configurar como una organización de poder político caracterizado por la división de poderes, el control legal del ejercicio del Estado y el respeto por las libertades individuales. Con dichos arreglos garantizaron un ejercicio del Estado que no solo apalancó los intereses de la clase burguesa sino que garantizó que sus agentes e instituciones no infringieran los derechos y las potestades privadas de los integrantes de dicha clase, todo lo anterior, al estar controlado y regulado por reglas legales e instituciones codificadas que definían qué podían y qué no podían hacer.

Es importante mencionar que los Estados Liberales de Derecho aunque se diferenciaron de sus predecesores los Estados Monárquicos Absolutistas (XV-XVIII) , es cierto también, fueron su continuidad. En ese sentido, terminaron la tarea de consolidar una unidad territorial nacional regida por autoridades e instituciones que en exclusiva monopolizaron el ejercicio de la dominación sobre el territorio y la población. Lograron instaurar centros únicos de gobierno y sistemas legales unificados, y además, consolidaron estructuras administrativas de alcance nacional (Poggi, 1978). Igualmente, consolidaron sistemas fiscales que les permitieron perdurar en el tiempo al hacer posible la extracción regular de recursos económicos bajo la forma de impuestos ${ }^{4}$. Estos otros atributos también entraron a integrar el aparato administrativo estatal o la administración pública moderna, ya que buena parte de su institucionalidad se configuró bajo el objetivo de cómo conseguir y manejar de manera permanente los impuestos con que subsistían los Estados Nación, e igualmente, en cómo llegar a hacer presencia en todos los territorios que entraron a integrarlos.

En el contexto histórico de las sociedades industriales y de los nacientes Estados Liberales es que hace presencia la obra de Charles Bonnin, la cual como se puede ver en sus planteamientos, ya impulsaba varios de los principios y componentes por los que empezaba a regirse unas y otros. Los individuos y la comunidad, el interés público y privado, la acción de las autoridades y los reglamentos, la jerarquía y los funcionarios, entre otras, serían nociones o categorías que utilizaría el autor en cuestión y que coincidirían con las creaciones institucionales que estaban tomando forma entre los siglos XIX y XX. Sus reflexiones, a su vez, anunciaban el temprano

4 Los elementos legales, administrativos y fiscales mencionados, son los antecedentes históricos de los actuales aparatos administrativos públicos. 
nacimiento moderno de la Administración Pública como una disciplina social con pretensiones científicas.

Pero la Administración Pública como disciplina científica no solo se consolidó entre los siglos XV al XX por saberes y autores europeos como los ya mencionados, sino también, fue desarrollada en colonias europeas. Producciones intelectuales sobre las Ciencias de la Policía, la Cameralística o la Ciencia Administrativa migrarían de Europa a las Américas ${ }^{5}$. Es el caso del territorio colonial de la Nueva Granada, en 1770, donde el fiscal Francisco Antonio Moreno Escandón en el marco de impulsar las reformas borbónicas del imperio español, propondría su enseñanza como parte de las transformaciones que consideraba fundamentales para modernizar al Estado y a la sociedad granadina. Fue así que con ocasión de la reforma educativa liderada por dicho personaje se empezaron a adoptar al interior de las instituciones educativas cursos de "derecho público", "derecho natural y de gentes". Con ello pretendía que los pobladores aprendieran "todo lo concerniente al gobierno interior del Estado" (Uribe, 1992, p.88).

Ganarían tal relevancia en la Nueva Granada las ciencias importadas, que una vez dichas colonias ganaron la independencia, entre 1830 y 1850, en Bogotá, Santa Marta, Cartagena, Socorro y San Gil, se impartieron cátedras para enseñar la Ciencia Administrativa. Destacadas figuras de la vida pública del siglo XIX como lo eran Vicente Azuero, Ezequiel Rojas, Mariano Ospina Rodríguez y José María Samper, se ocuparon de impartir los cursos respectivos. La relación sostenida por parte de los criollos con esos saberes de origen europeo no sólo fue de aprendizaje y difusión, sino también, de crítica y re-conceptualización. Importantes personajes públicos y altos funcionarios de la naciente República de la Nueva Granada discutieron y replantearon las tesis propuestas por los pensadores europeos ${ }^{6}$.

Entre dichos personajes se encuentran, Florentino González (1840), con su obra Elementos de Ciencia Administrativa. Bosquejo de un Sistema de Administración Pública para un Estado Republicano y, Cerbeleón Pinzón (1847), con su tratado sobre Principios sobre la Administración Pública ${ }^{7}$. A continuación se hará

5 Interesa en este apartado hacer algunas referencias al caso colombiano porque es desde éste donde se produce éstas reflexiones. Pero valga señalar, ese no será el énfasis ni el enfoque general de la totalidad de éste texto en las secciones y capítulos que siguen.

6 La República de la Nueva Granada décadas después se convertiría en la República de Colombia.

7 Las obras de Florentino González y de Cerbeleón Pinzón revisten total importancia ya que se puede pensar en ellas como "los clásicos de la administración pública colombiana". Sus trabajos permiten dilucidar cuál era el modelo de administración pública que se quería y se tenía en los nacientes tiempos 
referencia al primero de ellos para evidenciar como desde los "márgenes" coloniales de occidente se dio una relación crítica y creativa frente a la naciente Ciencia Administrativa. Tras ser encargado de la enseñanza de la cátedra de ciencia administrativa en el colegio San Bartolomé de Bogotá, Florentino González se dio cuenta de que lo que impartía no era una Ciencia, y peor aún, no correspondía a la realidad republicana de sus propios territorios. Indica Gonzáles que aunque intentó importar los aportes de pensadores europeos tales como los de Charles Bonnin, comprendió que, estos no se adaptaban a la realidad de su sociedad por olvidar los intereses de las localidades.

Encontraba González por ese camino que las leyes que regían la recién creada patria criolla se basaban en un espíritu centralizado que, a su entender, era el causante de los males que padecía la sociedad (González, 1994). Tras revisar lo acontecido en países como Estados Unidos y la Gran Bretaña, valoraba que los mejores modelos administrativos eran aquellos descentralizados. Para el autor en cuestión, en dichos países aunque había una administración centralizada para los asuntos más generales, lo demás, se dejaba al cuidado de las localidades y de sus habitantes. Tomando dichos aprendizajes, asumía que la administración municipal se presentaba como aquella que atendía los intereses y los negocios públicos de forma más eficaz y diligente, toda vez que, la diversidad de intereses florecientes en un país no podía ser atendida uniformemente por la administración nacional. Para González, factores naturales como la posición geográfica, el clima, los recursos, etc. facultaban a cada sección municipal para tener su propia autoridad administrativa. Además, consideraba que es sólo a través de dichas secciones, que se podía dar cabida a la práctica democrática y a los sentimientos de patriotismo.

Al igual que sus antecesores europeos, el pensador granadino, postula una misión y un objeto propio a la Ciencia Administrativa. Al respecto señala Florentino Gonzáles que:

La Ciencia Administrativa es el conocimiento de los principios, en virtud de los cuales debe de arreglarse la acción de las autoridades a quienes se encargue el manejo de los intereses y negocios sociales, que tienen el carácter de público. (González, 1994, p. 75).

Por su parte, en relación con la administración pública indica que:

de la incipiente república colombiana. Un papel clave en recuperar el segundo de los pensadores lo tuvo el profesor Jairo Díaz Pinzón de la Escuela Superior de Administración Pública (ESAP). Desde aquí, un reconocimiento a su trabajo. 
La administración pública es la acción de las autoridades sobre los intereses y negocios sociales, que tengan el carácter de público, ejercida conforme a las reglas que se hayan establecido en una nación para manejarlos" (González, 1994, p.75).

Una distinción interesante hace aparición en los planteamientos de Florentino González sobre la cual vale la pena llamar la atención. Para dicho autor, una cosa era la administración pública, y otra, la Ciencia de la Administración. Mientras la primera refería a la acción de las autoridades y las leyes sobre los negocios o los intereses sociales, la segunda, era la encargada de estudiar los principios por los cuales debía orientarse dicha acción. De tal manera, establecía dos dominios de actuación claramente diferenciados, el obrar y la reflexión, aunque articulados en una misma unidad de propósito: la acción administrativa. El elemento articulador entre los dominios del poder y del saber era la acción, ya que si los estudiosos se ocupaban de la práctica desarrollada por las autoridades, estas a su vez, atendían a los principios y recomendaciones que aquellos realizaban. Podría concluirse por consiguiente que, Florentino González aspiraba a constituir una ciencia reflexiva pero también práctica. Ciencia nunca distante y comprometida con la transformación de su objeto de estudio.

Con los planteamientos precedentes se cierran la caracterización de las tesis de González. Cabe decir que ellos efectivamente muestran que la Ciencia de la Administración llegó a territorios diferentes a los de los países europeos, e igualmente, que en ellos, la misma fue apropiada de manera crítica y creativa. Sin embargo, los planteamientos de González al igual que los de autores que le precedieron y que fueron referenciados aquí, son indicativos de un hecho de mayor trascendencia. Este alude a que desde siglos atrás se vienen produciendo esfuerzos intelectuales tendientes a instaurar una ciencia o saber que se ocupe de la acción del Estado sobre la sociedad: la Administración Pública. Con sus reflexiones y controversias, dichos pensadores no sólo atestiguaron el nacimiento de una disciplina, sino más allá, sembraron las semillas intelectuales con las que ella se empezó a edificar. Tales precursores permiten pensar que la Administración Pública como disciplina social cuenta con reflexiones intelectuales tan antiguas y significativas como lo tienen otras disciplinas o ciencias sociales.

Los precursores intelectuales de la Administración Pública ponen de presente algo fundamental, y que se valora aquí, en el momento actual se viene relegando. Se hace referencia a la alta estima que tuvieron por sus objetos de estudio, al punto de, querer inaugurar una reflexión sistemática conducente a erigir una ciencia que se ocupara de sus principios. El haber asumido 
dicha actitud, les permitió no caer en una tan frecuente en la actualidad, de considerar, que sobra estudiar el mundo de fenómenos administrativos por considerarlos un conjunto de procedimientos o prescripciones elementales sin mayor fundamento. Prejuicio y preconcepción que ha llevado en no pocos casos a considerar que orientar la acción del Estado sobre la sociedad "no posee ciencia alguna".

Igualmente los precursores de la Administración Pública como disciplina propusieron importantes pilares en torno a los cuales debía girar su estudio, y que a la fecha, siguen siendo válidos. En ese marco, vieron un pilar social, al tener como finalidad promover a la sociedad, sus negocios o sus relaciones sociales. Divisaron igualmente, un pilar político, alusivo al hecho de que mediante la administración debía asegurar ciertos propósitos comunes o colectivos relacionados con construir los intereses públicos o "la felicidad" de la población, Finalmente, divisaron un pilar instrumental, que los llevó a señalar a los reglamentos, las leyes o las autoridades como los medios a través de los cuales se podrían conseguir el ordenamiento de la sociedad. Sin embargo, y esto es esencial, los divisaron no por separado sino en su relación conjunta, sobre la base de la articulación que de ellos debía llegar a hacer la acción administrativa y gubernamental. En ese marco, es la acción administrativa y gubernativa con sus propósitos de transformar la sociedad, sobre la base de ciertos fines políticos, los que a juicio de varios de los precursores los que deben de orientar su estudio y proyección.

\section{La consolidación de la disciplina y su diversificación en el siglo XX}

Con la llegada del siglo XX, en particular en los Estados Unidos, hubo un considerable impulso en relación con promover y consolidar a la Administración Pública como una de las ciencias modernas. Los trabajos y visiones de Woodrow Wilson, Frank Goodnow, Leonard White y Wight Waldo tuvieron una enorme influencia en dicha tarea al buscar darle a la disciplina unos objetos de estudio propios y diferenciados. El primero de ellos, Woodrow Wilson (1887), a quien en Norteamérica se le considera el padre de la Administración Pública como disciplina y que llegó a ser Presidente de los EE.UU (1913-1921), consideró que el objeto de estudio de la Administración Pública era dilucidar qué es lo que el gobierno puede hacer bien, y en consecuencia, descubrir la manera en que dichas actividades podían realizarse en forma eficiente y apropiada. En su momento, le surge de entrada un problema central a Wilson al intentar dar vida en su país a una ciencia de la administración. 
En el diagnóstico que hace de su época, encuentra que en su país no había estudios teóricos fuertes acerca de métodos y/o técnicas que constituyeran una buena administración. Encontraba entonces un bajo desarrollo de la ciencia administrativa en Estados Unidos que la imputaba a que éste país no había tenido grandes dificultades a la hora de ejercer la función de gobierno, y además, aunque se habían realizado estudios incipientes en torno a los procedimientos de gobierno, estos se habían centrado más pensando en el Legislativo que en el Ejecutivo. En contraste, Wilson identifica que en los países trasatlánticos de Europa sí se habían realizado estudios serios, a los cuales valoraba como unos donde sí se habían formulado principios para perfeccionar los métodos y la organización gubernamental. En ese sentido, veía como imperioso el estudiar las formas y funciones administrativas de los países continentales tales como Alemania y Francia, que por lo demás, consideraba fueron los países en donde se inició el estudio de la administración pública. (Wilson, [1887], 1990).

El reconocimiento de la notable ventaja que divisa Wilson en los países europeos continentales le lleva a plantear la importancia de aplicar los principios generales de la administración europea al sistema administrativo estadounidense. Consideraba que tal proceder no debía llevar a descuidar las particularidades sociales y políticas inherentes a cada tipo de sociedad, aunque no escatimaba, que persistiera el temor en su sociedad de buscar en sistemas extranjeros elementos administrativos. Pare él, estas preocupaciones eran infundadas dado que, en primer lugar, las formas de gobierno de los países a pesar de sus diferencias tenían semejanzas grandes, y en segundo lugar, en todos los sistemas de gobierno los fines de la administración debían ser los mismos (Wilson, [1887], 1990).

Para evitar que se presentara una confusión al momento de estudiar sistemas administrativos extranjeros y tenerlos en cuenta para rediseñar los de EE.UU, señalaba Wilson que, era necesario que persistiera la separación entre política y administración. En su consideración, de mantener dicha separación dependería el mantenimiento de los principios democráticos estadounidenses aplicados a una administración pública al servicio de los intereses generales. Por ese camino, la administración debía mantenerse como un elemento exterior a la puja y manipulación de los intereses propios de la esfera política. Al respecto señala Wilson que:

Las cuestiones administrativas no son cuestiones políticas. Aunque la política fija las tareas de la administración, ésta no debe tolerar que se manipulen sus funciones (Wilson, [1887], 1990, p.85). 
En un contexto democrático como el que divisa Wilson para los EE.UU. a finales del siglo XIX e inicios del XX, considera el pensador en cuestión, que la administración pública debe seguir el principio de la soberanía popular. Asumirlo implica una tarea nada fácil de cumplir, ya que requiere entre el gobierno y la sociedad un largo proceso de negociaciones, acuerdos y desacuerdos, pasos adelante y pasos atrás, con miras a lograr un consenso multitudinario construido en el marco de una plétora de opiniones. Para llevar a cabo las reformas requeridas, para Wilson, la administración debe persuadir a los ciudadanos acerca de la necesidad de realizar cambios oportunos y debe conducirlos a la búsqueda de una opinión correcta acerca de hacía donde deben orientarse dichos cambios.

En la perspectiva de Woodrow Wilson, la opinión pública debe jugar el papel de crítico principal respecto a la conducción de la administración, ya que sólo con ella se podría evitar que el cuerpo de funcionarios públicos se convirtiera en un conjunto de burócratas totalmente ajeno a los intereses y necesidades de los ciudadanos. La opinión pública debe desempeñar entonces el papel de crítico autorizado respecto al ejercicio de la administración, pero dicha crítica a su entender, debe ser sana, benéfica e indispensable. (Wilson, 1990). El público en general, debe dedicarse a la vigilancia de las grandes fuerzas políticas y administrativas absteniéndose de ejercer directamente supervisión en los medios diarios del gobierno. Para Wilson, es necesario que el público sea instruido acerca de los asuntos nacionales, siendo capaz de asumir el embarcarse en unos pero también abstenerse de discutir otros. Debe buscarse la forma para que la opinión pública sea eficiente y no sea entrometida en asuntos que les competen exclusivamente a las autoridades gubernamentales. Hasta aquí, los planteamientos de Wilson.

Otro pensador norteamericano que apostó a pensar la administración pública en EE.UU a finales del siglo XIX e inicios del XX, fue Frank Goodnow (1900). Profesor de destacadas universidades norteamericanas y comisionado del gobierno, dicho intelectual parte por afirmar que en el lenguaje tradicional tiende a existir una confusión a la hora de conceptualizar los términos de "política" y "administración". Para clarificarlos, precisa que mientras que la política orienta la acción gubernamental y expresa la voluntad del Estado, la administración es la encargada de hacer cumplir dicha voluntad. A su entender, aunque necesariamente una y otra deben ser objeto de una clara diferenciación conceptual, en la práctica, resulta completamente 
improcedente y equivocado asignar las funciones administrativas y políticas a instancias separadas e independientes. Por lo mismo, Goodnow resalta la complementariedad de dichas funciones y afirma que mientras la política es la expresión de la voluntad del Estado, la administración es la encargada de poner en práctica dicha voluntad.

Para Goodnow, el principio de separación de los poderes, en su postura extrema, no puede ser el pilar de las organizaciones políticas y administrativas, pues si ello ocurre, cada autoridad se limitaría a cumplir exclusivamente lo asignado. Por el contrario, debe existir una armonía entre expresión y cumplimiento de la voluntad estatal, y para que la haya, es preciso que uno de los dos órganos que expresa la respectiva función de gobierno sea dependiente del otro. Respecto a este dilema, a su entender, el pueblo ha decidido que sea la autoridad ejecutiva la que se subordine a la expresiva de la voluntad que reside en el legislativo. Al ser la condición "legislativa" la que a través de la representación política encarna la voluntad del pueblo, la ejecutiva debe subordinarse.

Otro autor que también alimentó el pensamiento administrativo norteamericano fue Leonard White, profesor, investigador y comisionado de gobierno. Señala el autor en cuestión que, el creciente interés que tuvo la Administración Pública en el siglo XX encontró su origen en varias causas. Una de ellas, estuvo expresada en los reclamos hechos por la población tras observar una alta carga de impuestos y unos gastos improcedentes. Otra causa radicó en que, dada la competencia en el mercado mundial se debía entrar a contemplar un uso más eficiente de los recursos públicos y una reducción de los costos de producción. Una causa adicional, se derivaba de la realización práctica de los programas legislativos que eran un aliciente para mejorar los métodos y procedimientos administrativos (White, [1926], 1990).

A un nivel epistemológico, White consideró que aunque en la década de los años 20 del siglo XX existía una abundante producción en la Administración Pública estadounidense, dichos estudios carecían de un análisis sistemático de sus instituciones y prácticas. Señalaba entonces que el estudio administrativo debía recabar en aspectos que fueran más allá de las tareas prácticas de los empleados públicos, para lo cual, a su entender, requería un esfuerzo teórico bastante amplio. En el camino de lograr una adecuada comprensión de la Administración Pública, para White, ella debía distinguirse del derecho, ya que consideraba que aquella tenía por función la eficiente dirección de los asuntos públicos mientras el objetivo del derecho administrativo era 
la protección hecha por las autoridades a los derechos privados. (White, [1926], 1990).

Para White una adecuada comprensión de la administración pública pasaba también por divisarla como un proceso continuo que trascendiera las dinámicas históricas específicas de las sociedades y los atributos específicos de los niveles de gobierno. En tal sentido, resultaba erróneo estudiar la administración municipal, nacional o estatal, como si fueran aspectos separados e independientes unos de otros. White asumía por consiguiente que, el proceso administrativo era "una secuencia ininterrumpida de desarrollo" común a todos los niveles de gobierno y a sus formas históricas particulares. En ese marco, en un sentido genérico y universal, concebía a la administración pública como la administración de hombres y materiales en miras a lograr los objetivos del Estado. Dicha forma de pensarla, para White, tenía varias ventajas: enfocaba el aspecto empresarial de la administración pública dejando un poco de lado su formalismo; articulaba la dirección de los temas de gobierno con los propios de otras organizaciones sociales; dejaba abierta la cuestión acerca de hasta qué punto la administración participaba en la configuración de los objetivos del Estado y; esquivaba todo conflicto en torno a la naturaleza de la acción administrativa.

En términos de White, para una correcta administración debía existir la división especializada del trabajo y los cargos debían estar sometidos a métodos y procesos previamente establecidos para que los funcionarios procedieran de forma ordenada y correctamente planeada. En ese sentido, el autor recalcaba que todo Estado democrático moderno debía basar su sistema administrativo en principios burocráticos de tipología weberiana: permanencia en el cargo, preparación especializada para desempeñar cargos oficiales, interés profesional por parte del funcionario y primacía del criterio de cumplimiento de los propósitos del Estado. En ese marco, el objetivo de la administración era "la realización más expedita, económica y completa de los programas públicos" (White, [1926], 1990, p.131). Para lo anterior, su accionar debía realizarse en forma eficiente, garantizando el menor uso de recursos humanos y materiales puestos a disponibilidad de funcionarios y agentes estatales. Igualmente, debía propender por el logro inmediato y completo de los propósitos formulados por la organización del Estado, y además, debía velar porque no hubiera despilfarro en el uso de sus recursos, esforzándose más bien, porque hubiera ahorro de los mismos.

Para Leonard White, la administración pública debía llevar a un trabajo articulado con las otras ramas del gobierno y con el sector privado. 
Consideraba que aunque tradicionalmente se la había relegado a los asuntos meramente ejecutivos, cada vez más, tenía injerencia en los asuntos legislativos y la asignación de recursos. La ingente cantidad de tareas que debía enfrentar en virtud de su conexión con otras ramas del poder público, a su entender, hacía imperiosa la necesidad de adoptar para todo el Estado características de la administración burocrática. Esto llevaba a White a entrar en otro campo cuál era el de conceptualizar qué era el Estado en su época. A su entender, el laissezfairismo así como los gobiernos irresponsables de Europa, plantearon la necesidad de reducir al mínimo la intervención del Estado limitándolo a tareas de defensa y policía. Sin embargo, el proceso de la revolución industrial así como sus consecuencias sociales, económicas y políticas llevaron a reformular al mismo y a su administración pública. Tales procesos, condujeron a generar un ensanche en las áreas intervenidas y de competencia de la administración, así como, de los problemas que se ocupaba y de sus funciones primordiales.

Para White la creciente lucha de clases por la distribución del producto social condujo a que interviniera el Estado en la protección de los sectores más débiles y vulnerables de la sociedad. Igualmente, la acción de grupos reformadores, provocó que se inmiscuyera en todo tipo de materias para regularlas y/o prohibirlas. El aumento de tareas del Estado moderno lleva al autor en cuestión entonces a concebirlo "como un gran organismo de cooperación social" instaurado para el mejoramiento social y que regula a la sociedad sin desmedro de sus tradicionales funciones represivas. A criterio de White, esa variedad amplia de frentes cada vez más extensos a los que debió atender el Estado confluyeron a promover una tendencia a favor de una administración científica que propugnara por mejorar los métodos administrativos. Finalmente, aclara White, a pesar del enorme esfuerzo realizado para conseguir tal tipo de administración en su momento, sus logros eran magros y habían causado gran insatisfacción en comparación con los métodos antiguos. A su entender, la promesa de una mejor vida para los estadounidenses no sería realidad concreta en tanto la administración de su época no abandonase "los surcos en donde ella fue dejada durante un siglo de abandono".

Con White se da por terminado un conjunto de autores y perspectivas intelectuales que expresan el interés y desarrollo que empezó a ganar la Administración Pública como disciplina en los EE.UU en la primera mitad del siglo XX. Respecto a cómo valorar los aportes de todos esos autores y perspectivas se puede traer a colación las reflexiones realizadas por otro 
importante pensador norteamericano:Wight Waldo. Este hace un balance de lo alcanzado por la disciplina hasta mediados del siglo XX en el contexto de los EE.UU, y sobre dicha base, juzgaba que el conjunto teórico de estudios consolidados respecto a la Administración Pública expresaba signos de creciente fuerza y capacidad crítica(Waldo [1948],1990). Dado lo anterior, consideraba que podía esperarse en el inmediato futuro una sólida creación de teoría administrativa. Para conseguirlo, debía de tenerse en cuenta que había muchas dudas que resolver, varios problemas teóricos por tratar y una gran cantidad de importantes focos de desarrollo teórico por atender. Además, ese desarrollo de la Administración Pública por construir, no podían hacerse al margen de los nuevos acontecimientos que ocurrían en aquella época, como lo eran los relacionados con las nuevas condiciones económicas y sociales dejados por la Segunda Guerra Mundial. Similar importancia, le daba a las nuevas formas y métodos de cooperación internacional derivadas de la postguerra.

Las consideraciones de Waldo realizan una breve fotografía de los alcances logrados por los distintos desarrollos de la Administración Pública como disciplina científica o social en Norteamérica en lo que atañe a lo acontecido con ella en la primera mitad del siglo XX. Sin embargo, como se revela en los propios planteamientos de Woodrow Wilson, Frank Goodnow, Leonard White y Wight Waldo, tales desarrollos de la disciplina no pueden ser entendidos al margen de los procesos históricos vividos por la sociedad norteamericana en dicho período. No debe perderse de vista que las producciones intelectuales de dichos autores reseñados emergieron en relación directa con procesos, problemas y desafios de su época y de sus respectivos contextos sociales. Dichas producciones hay que leerlas como tributarias, pero también, como forjadoras de una sociedad en movimiento como lo era la estadounidense. Pero... ¿Por qué en movimiento?.

Los EE.UU de inicios del siglo XX y de su primera mitad era una sociedad compleja y en transformación, la cual estaba inmersa en procesos acelerados de industrialización y de urbanización, donde las relaciones mercantiles de tipo capitalista empezaban a comandar los distintos frentes que conformaban la vida social. En aquel momento, así mismo, era una colectividad nacional con tensiones entre clases sociales donde la vinculada al mundo del trabajo, exigió y generó nuevas demandas y servicios sociales al Estado. Esa sociedad, además, era una donde la ciencia y la tecnología cobraron un valor y significado cada vez mayor por introducirse en el corazón de las industrias y en la vida de las personas (Fischer, 2009). A los patrones y desafios anotados, 
la norteamericana era una colectividad con crisis económicas y sociales, donde las más evidentes de ellas, eran "los años de la depresión", las situaciones sociales de entreguerras y las postguerras.

Esos procesos y desafios vividos por la sociedad norteamericana en la primera mitad del siglo XX condujeron paulatinamente a edificar esa forma de Estado, conocido hoy, como el Welfare State o el Estado del Bienestar. Dicha forma estatal significó un enorme impulsó y dinamismo para la administración pública como fenómeno institucional, ya que no solamente implicó la creación de un conjunto grande de sectores y organizaciones públicas para intervenir la sociedad, sino también, demandó de manera amplia el reclutamiento de personal con conocimientos especializados. (Nelson, 2001). Además, implicó la demanda de saberes que soportados en la ciencia y en la tecnología prestaran soporte a la actividad gubernamental y a la formación de los cuadros y funcionarios. De esto último, precisamente, brindan testimonio muchos de los planteamientos ya referidos por Wilson, Goodnow, White y Waldo que con sus creaciones intelectuales expresan una oferta de saberes con pretensiones científicas para una sociedad en desarrollo que los demandaba.

\section{Del debate del objeto a la especificidad del campo de estudio}

A pesar del impulso y el optimismo que rodeó la Administración Pública como disciplina científica en Norteamérica en la primera mitad del siglo $\mathrm{XX}$, en la segunda mitad que le siguió, al interior del campo de estudio se desató una intensa discusión de si la Administración Pública podía considerarse y tener el estatus de ciencia. El punto en cuestión, era si podía contar con un referente de estudio singular que le permitiera diferenciarse y fijar límites claros frente a otros tipos de disciplinas que se ocupaban de la realidad social (Sánchez, 2001). Algunos asimilaron dicha discusión como una manifestación de una disciplina en crisis, o con crisis de identidad, que remitía a un conflicto por el reconocimiento y la legitimidad de la Administración Pública como ciencia (Vigoda, 2001). En el marco de dicho debate, algunas posturas asumieron que ella dificilmente podría ser un saber con carácter científico por no tener claro cuál era su objeto de estudio y cuáles eran las teorías centrales que la soportaban. A ellas se sumaron otras posturas en las cuales se asumía que no podía otorgársele un estatus científico, al tratarse de un conocimiento de naturaleza pragmática al cual le bastaba un adiestramiento en desarrollos cognitivos generados por diversas disciplinas (Sánchez, 2001). En tal sentido, para estas otras posturas era suficiente que en 
su construcción y aprendizaje confluyeran los aportes generados por otros campos de conocimiento, sin tener por ello, que contar con un objeto de estudio específico.

A dichas posturas reaccionarían otras que consideraban a la Administración Pública como un saber que si podía aspirar a constituirse en una disciplina científica, al contar con su propio objeto de estudio y con teorías propias. Los defensores de estas posturas aunque asumían que la Administración Publica si era un saber científico, tenían el problema, de no coincidir respecto a cuál debía ser finalmente su objeto de estudio. El análisis elaborado por José Juan González (2009) muestra la amplitud de objetos que llegaron a postularse y a estudiarse por parte de quienes asumieron que la administración pública era una ciencia.

Al respecto, González señala que autores como Herbert Simón, Robert Merton, Elton Mayo, entre otros, apuntaban a que la Administración Pública debía ocuparse del estudio de las organizaciones. Por su parte, Frederick Taylor, Charles Merrian, Luther Gulick y otros, se inclinaban a considerar que ella debía ocuparse de las organizaciones y de los procesos de gestión desde disciplinas diversas. Desde autores como Max Weber, Michel Crozier o Harold Laski, entre otros, la burocracia debía constituirse en uno de los principales objetos de estudio de la Administración Pública. Por su parte, para autores como Woodrow Wilson, Frank Goodnow, Guillermo Willoughby y Richard Ross, el objeto de estudio debía ser el gobierno. Para autores como Woodrow Wilson u Omar Guerrero, el estudio de la Administración Pública debía centrarse en la rama ejecutiva como centro de poder del Estado. Mientras que para pensadores como Harold Stein, Harold D. Lasswell, Charles Lindblom, entre otros, el foco de la Administración Pública debía ser las políticas públicas. Un grupo más reciente de autores como Renate Mayntz, Manuel Alcántara, Guy Peters, entre otros, el estudio de la Administración Pública debía dirigirse a la gobernabilidad y la gobernanza.

A pesar de la variedad de objetos de estudio postulados por los autores atrás relacionados respecto a la Administración Pública como una ciencia, una síntesis de ellos puede agruparlos en dos grandes concepciones. Desde una concepción, partiendo de un supuesto universalismo de la Administración, se equipara a la Administración Privada con la Administración Pública al divisar que sus objetos de estudio tienen diferencias de grado pero no de naturaleza. En este caso se divisa a la administración pública compartiendo un tronco afín y común con la de tipo privado, y desde tal postura, se asume que el estudio de la administración hace presencia en todos aquellos lugares donde exista la 
preocupación por la eficiencia y la eficacia en las organizaciones, e igualmente, donde haga presencia la acción social orientada a lograr la cooperación colectiva entre humanos para la consecución de determinados fines.

Otra concepción que asume a la Administración Pública como una ciencia, la divisa como no equiparable a la Privada al presuponer que ella como ciencia se ocupa de un fenómeno político no susceptible de asimilarse a otros de tipo privado, que lo llevan a tener fines, lógicas y funciones diametralmente distintas (Chevallier, 2001). Atribuye en este sentido al objeto de estudio de la administración pública, una naturaleza política ligado a la dominación, el direccionamiento y la reproducción de la sociedad en su conjunto por medio del Estado, en tanto que la privada, la liga a la empresa capitalista y su ganancia. No obstante, el acuerdo entre autores agrupados en esta concepción empieza a desdibujarse cuando se trata de precisar cuál es el componente o dimensión del Estado que debe estudiarse: si es el Estado en su totalidad, si es el Gobierno, si son las Organizaciones Públicas, si son las Políticas Públicas, si es la Gobernanza etc.. Más aún, si son algunos de ellos o el conjunto total de los mismos.

Sin importar si el objeto de estudio de la Administración Pública es asumido desde un ámbito agrupado a partir de una supuesta naturaleza genérica y universal, o así mismo, a partir de una naturaleza política, ambas concepciones conducen a afirmar que ella puede efectivamente constituirse como disciplina social o científica. Pero los pensadores que estaban detrás de las perspectivas mencionadas terminaron no solo por creer que la Administración Pública era una ciencia, sino que dieron un paso adelante, y terminaron por constituirla. Esto se afirma, porque al hacer cada uno de ellos un número significativo de investigaciones paulatinamente fueron alimentando un campo con diversos objetos, énfasis y enfoques, cuyo denominador común, fue la convergencia en la importancia de comprender, explicar, proyectar y discutir realidades administrativas sobre la base de la observación, el análisis y la discusión sistemática y acumulativa. En esa producción intelectual de cada uno no se encontró ni se llegó al acuerdo de un objeto único de estudio, sino más bien, edificaron objetos de investigación superpuestos y con fronteras porosas entre sí que terminaron por conformar un campo de estudios y de investigaciones denominado Administración Publica . Campo con pretensiones científicas donde resulta claramente imposible fijar los límites, y que se centra más bien, en encontrar las articulaciones entre los diversos objetos de los que se ocupa ${ }^{8}$.

8 Se trata de un campo donde se hace difícil interrogar dónde termina la reflexión sobre el Estado y 
Considerar que la Administración Publica se constituyó como un campo científico por la producción intelectual de todos esos autores, puede parecer una visión ligera, sin embargo, no lo es. Hoy por hoy el debate sobre la cientificidad de una disciplina social no descansa en que pueda probarse que tiene un sólo objeto de reflexión e investigación claramente delimitado, y menos aún, de un método del cual haga uso en exclusiva. En disciplinas como la ciencia política, la sociología, la antropología, la psicología, e incluso la economía, existe una profunda discusión en torno a cuál debe ser su objeto de estudio y cuáles los métodos que deben ser privilegiados para abordarlos 9 . Por ello, se reconoce a su interior, que antes que existir un único objeto que les permitiría reconocerse y progresar como ciencia, más bien, existe un campo donde coexisten y confluyen diversos objetos, enfoques y métodos. A la disciplina de la Administración Pública habría que aplicársele igual rasero, y con ello decir que su estatuto científico no depende de tener un objeto o método único de conocimiento, sino más bien, de tener una multiplicidad de ellos que con fronteras porosas se comunican entre sí. Objetos que disputan pretensiones de validez según convenciones, protocolos y evidencias socialmente instauradas al interior del mismo campo y de otros que intercambian con él.

\section{¿Qué puede ser estudiado en el campo de la Administración Pública como disciplina científica?}

No se cierra la discusión con asumir que la Administración Pública es una disciplina social y científica organizada alrededor de un campo de estudio con objetos relacionados entre sí. En coincidencia con lo que aparece en diversos textos, compilaciones y encuentros, los objetos de los que se ocupa su estudio no son tan numerosos como parece, ya que ciertos focos son reiterativos y dominantes en los trabajos académicos e investigativos que la abordan. No se pretende aquí enunciarlos y caracterizarlos a todos, sino más

dónde empieza la del gobierno; o también, dónde termina la referida a gobierno y donde empieza la de organizaciones públicas; 0 así mismo, dónde termina la de las organizaciones públicas y dónde empieza las de las políticas públicas.

9 Un ejemplo de esto se expresa en la ciencia política donde se interroga si su objeto se centra, entre otros, 0 en el Estado, o en el sistema político, o en el régimen político, o en el poder, o en la política, 0 en lo político. En la ciencia económica se interroga así mismo, entre otros, si su objeto se refiere a la producción y distribución de la riqueza social, o al manejo de los recursos escasos de la sociedad, o a la oferta y la demanda agregada regulada por el mecanismo de precios, o a la elección racional en las transacciones entre agentes económicos. En psicología, por su parte, se interroga si su objeto de estudio es, entre otros, o las conductas y los comportamientos de los seres humanos, o sus procesos mentales y cognitivos, o sus fuerzas conscientes, inconscientes y preconscientes, o sus emociones y representaciones mentales acorde a los sistemas sociales. 
bien, se propondrá una articulación coherente de algunos de ellos que se consideran centrales, y que permiten, trazar unas fronteras epistemológicas respecto a lo que ella debe y no debe de estudiar. Una definición que inicialmente los presenta y los articula de manera coherente, construida provisionalmente, es la siguiente:

La Administración Pública se ocupa del estudio de fenómenos públicopolíticos articulados a través del Estado en Acción en sus componentes de organizaciones públicas, de gobierno, de políticas públicas, de dominación y de gestión, que no son comprensibles sin atender a los procesos desatados por el gobierno y el Estado en sus relaciones con la sociedad.

Se pasará entonces a desarrollar dicha definición. La administración tiene una naturaleza pública y política porque todas sus configuraciones están relacionadas con fenómenos colectivos de poder donde está en juego la conducción política de las sociedades. Por lo mismo, ella está atada a procesos de autoridad y de gobierno encaminados a direccionar a las poblaciones a fines establecidos mediante ejercicios políticos, teniendo para ello como base, una institucionalidad pública de diferente tipo. Esta institucionalidad se materializa entre otros, en sistemas legales, formas organizacionales, políticas públicas y procesos de gestión, los cuales son diseminados y anclados en diversos puntos del territorio para dar forma y dirección a las relaciones sociales.

Actuar e intervenir la sociedad con fines políticos mediante ejercicios de autoridad y de gobierno, pero también en contextos democráticos de consenso y de cooperación, marcan la especificidad de la naturaleza pública y política de la administración pública como fenómeno histórico e institucional moderno. Asumir a la administración pública como un fenómeno de naturaleza política y pública no significa que su estudio se ocupa de todo lo concerniente a lo Político, lo Público o el Estado. En este último caso, la Administración Pública debe enfocarse solamente en lo referente al Estado y al gobierno en acción (Caiden, 2009). En tal sentido, debe prestar especial atención al hacer, a los procesos, los resultados y a los productos que se desprenden de su accionar, sin por ello dejar de atender fuerzas de distinta naturaleza que mueven y organizan el Estado (fuerzas políticas, económicas, sociales y culturales). Su foco de atención entonces, es esa parte que ha sido y que es la responsable de conseguir que se realicen y materialicen los propósitos, ideas y deseos políticos del Estado (Caiden, 2009).

La Administración Pública entonces no se ocupa del estudio todas las dimensiones que hacen parte del Estado sino, fundamentalmente, de esa parte 
administrativa responsable de producir los bienes, servicios y regulaciones con que se comprometen los Estados respecto a la sociedad. Que se ocupe del estudio del Estado Administrativo o en Acción no resuelve del todo el problema de la delimitación del campo de estudio que debe trabajar como disciplina. Al respecto, surge el interrogante de ¿cuál es, o qué es, o dónde se puede encontrar esa parte del Estado Administrativo que se ocupa del hacer, de los procesos y de los resultados? A responder dichos interrogantes, puede contribuir un componente clave del Estado, a saber, sus organizaciones públicas. Renate Mayntz (1985) señala que la administración pública como fenómeno histórico e institucional propio de las sociedades modernas ha de ser entendida como ese conjunto de organizaciones públicas, las cuales, relacionadas entre sí, conformaron un extenso sistema administrativo que entra a intervenir la sociedad. En tal sentido, es ininteligible la Administración Pública si no se ocupa como parte de sus objetos de estudio, las características del sistema de organizaciones que conforman la administración pública de un país. Bajo esta óptica, sólo es comprensible si se lleva a cabo el análisis de las actuaciones, procesos y productos del conjunto de las organizaciones públicas en su relación con la sociedad.

Además, la Administración Pública debe incluir como uno de sus focos de estudio las respectivas relaciones de tales unidades organizacionales con su medio ambiente organizacional, y sobre todo, debe dar cuenta de las relaciones y sentidos que se tejen entre ellas con ocasión de su multiplicidad e interdependencia mutua (Mayntz, 1985). Tal mirada, que reconoce como uno de sus focos de estudio a las organizaciones públicas, no debe hacerse a expensas de un abordaje que se desentienda de la vida interna de ellas y del mejoramiento de su desempeño. Por eso, no puede dejarse de lado lo planteado por Herbert Simón en los años 70, quien consideraba que el estudio de la Administración Pública debía ocuparse "de cómo debe ser construida y gobernada una organización para que cumpla eficientemente su propósito" (Carrillo, 2003).

Realizando conexiones y conjeturas, puede decirse entonces que el Estado Administrativo es esa parte del Estado integrado por el sistema de organizaciones públicas que prestan bienes, servicios o regulaciones a la sociedad; de él debe de ocuparse el estudio de la Administración Publica como disciplina científica. Aunque lo atrás señalado sea un avance, no se considera aún, que con ello quede zanjada la cuestión. En ese sentido, se acoge un componente más, y es que aunque en las sociedades modernas la administración pública como fenómeno histórico e institucional es un 
sistema de organizaciones públicas, es también y sobre todo, un campo de dominación política. Por lo mismo, estudiar cómo esas organizaciones públicas que conforman el Estado también se caracterizan por relaciones y ejercicios de poder a su interior y frente a su exterior social, es parte de los objetos de estudio que debe de ocuparse la Administración Pública como disciplina social. Una estructura fundamental en este proceso de dominación lo es la burocracia, comprendida esta como un sistema estructurado a partir de diversos elementos o componentes tales como las jerarquías de autoridad, la división del trabajo, los cuerpos especializados de funcionarios, la acción fundamentada en la experticia del conocimiento, la incorporación y promoción meritoria de sus agentes (Farazman, 2009). Así mismo, entendida desde los conflictos y rivalidades entre agentes, sectores, niveles y unidades administrativas en sus nexos con la sociedad y que se hallan enfrentados por recursos de poder (Chevallier, 1997).

Con el componente de dominación política aunque se avanza en la comprensión de aquello que estructura el Estado en Acción y su sistema de organizaciones públicas, se considera, no queda aún comprendida en su totalidad la variedad de componentes que lo integran. Falta agregarle a su configuración compleja el gobierno, las políticas públicas y los procesos de gestión. Respecto al primero de ellos, al gobierno, aunque es claro que es un órgano que suele distinguirse y diferenciarse del aparato organizacional administrativo, también es cierto, que es un eslabón sin el cual se hace imposible comprender a la administración pública como fenómeno institucional e histórico. Dicho órgano constituido generalmente a nivel nacional por presidente y ministros, y a nivel local por gobernadores, alcaldes y secretarios, es el que al interior del Estado dirige a las organizaciones públicas mediante la designación y el nombramiento de sus cabezas directivas. Igualmente, las rige a través de la generación de directrices formuladas mediante sus programas de gobierno y las conecta con las decisiones destiladas en las grandes arenas políticas del Estado (congreso, cortes, tribunales, partidos) (Keman, 2012). El gobierno debe entonces hacer parte del campo de objetos de los cuales debe ocuparse el estudio de la Administración Pública como disciplina científica, sin embargo, es importante aclarar, el mismo no es un objeto privativo de ella al ser fronterizo y transicional con abordajes provenientes de otras disciplinas como la ciencia política o el derecho, que también se ocupan del mismo.

El gobierno lleva a postular otro de los componentes propios del Estado en Acción y sus sistemas de organizaciones públicas. Se hace referencia a 
las políticas públicas, entendidas estas como los programas de acción que estructurados con la participación de las autoridades públicas en relación con la sociedad, son los dispositivos mediante los cuales se buscan intervenir las relaciones sociales para transformar situaciones asumidas como socialmente problemáticas ${ }^{10}$. Al proponerse mediante ellas objetivos y metas de gobierno y de Estado, las mismas direccionan, organizan y transversalizan la acción del aparato administrativo y del gobierno, y organizan las relaciones de dominación que desde el mismo se despliega hacia la sociedad ${ }^{11}$. A las políticas públicas, se suman los procesos de gestión, que hacen referencia, de una parte, al conjunto de acciones encaminadas a lograr la coordinación y/o cooperación planificada de diversos agentes y recursos para la consecución puntual de propósitos o productos al interior de las organizaciones o las políticas, y de otra, al conjunto de iniciativas emprendidas por servidores, funcionarios y gobernantes para apalancar recursos y apoyos que permitan la consecución de determinados objetivos.

Un último componente propio de la administración pública como fenómeno histórico e institucional hace referencia a las relaciones que sostiene el aparato administrativo público con la sociedad. Estas incluyen los procesos de conflicto y concertación sostenidos por las organizaciones públicas, las burocracias y los gobiernos con los diferentes actores, sectores y clases que conforman la sociedad. Alude, en primer lugar, a las prácticas, procesos y estructuras formales e informales de conflictividad individual y colectiva ordenadas a partir de los regímenes de derechos y deberes que se tejen entre Estado y Sociedad. Igualmente, hace referencia a los canales, diques y escalonamientos formales e informales que posibilitan o impiden el acceso de sectores de la sociedad a los diferentes centros del poder administrativo y del Estado. En este marco, de las relaciones entre administración pública y la sociedad, se encuentran los espacios de mediación, representación y

10 Aquí se asume esta concepción particular de lo que es una política pública. Sin embargo, varias definiciones públicas se han acuñado. Al respecto, se dice de ella que es "todo aquello que los gobiernos deciden hacer o no hacer" (Thomas Dye); "Una acción gubernamental dirigida hacia el logro de objetivos fuera de ella misma" (Heclo y Wildavsky). "El conjunto de actividades de las instituciones de gobierno, actuando directamente 0 a través de agentes, y que van dirigidas a tener una influencia determinada sobre la vida de los ciudadanos» (Guy Peters). "La acción de las autoridades públicas en el seno de la sociedad...la política pública se transforma en un programa de acción de una autoridad pública", (Mény y Thoenig).

11 Aunque las políticas públicas inicialmente se configuraron como un sub campo de estudio de la ciencia política, y luego pasaron a configurarse un campo autónomo denominado de las ciencias de las políticas, en las últimas décadas, han diluido sus límites y compartido su conocimiento con la Administración Pública (Thoening, 2003). Motivaciones teóricas y prácticas explican dicha dilución. Al ser una forma particular de configuración de la acción pública cae en el registro de fenómenos que estudia la Administración 
participación, pero también de queja y reclamo entre los actores sociales y los agentes e instituciones administrativas.

Se han señalado los componentes o elementos que se consideran deben ser objeto de estudio de la Administración Pública como disciplina científica: el Estado en Acción, las organizaciones públicas, la dominación por efecto de las burocracias, los gobiernos, las políticas públicas, los procesos de gestión y las relaciones Estado-Sociedad. Dichos elementos, tienen vasos comunicantes entre si y mutuas articulaciones, y los mismos aunque dan lugar a un campo relativamente amplio de experiencia de lo social, también acotan y delimitan el campo de estudios de la Administración Pública como disciplina científica y social. Implica por ejemplo que, no cualquier objeto administrativo, o del Estado, o de la sociedad, sea y pueda ser objeto de indagación de ella. Así, no es objeto de su estudio ni las organizaciones privadas o la gestión empresarial; tampoco fenómenos políticos tales como los partidos políticos, los regímenes políticos, los sistemas políticos o el Estado en su totalidad; no lo son igualmente los grupos, colectivos u organizaciones sociales. No importa, que los mismos según situaciones específicas deban incluirse al tener relación con el mundo administrativo.

Los componentes hasta aquí señalados, en su mayoría, hacen referencia a la administración pública estatal. Sin embargo, aunque esta domine el campo de estudios también hay otra menos visible referida a la administración pública de carácter no estatal. Esta otra perspectiva nace de otras visiones y experiencias históricas. Desde hace algunas décadas se puso en evidencia que lo público no es sinónimo de lo estatal, y en ese marco, se constató que hay funciones públicas sociales que no son privativas del Estado. Estas hacen referencia a provisión servicios públicos sociales (educación, protección o salud etc.) o a procesos de control social de la gestión que se hacen o ejecutan desde la sociedad (Cunill, 1997). A lo anterior se suma, que hay formas de provisión y administración de bienes y servicios comunales que no pasan por el Estado y que son realizados mediante acciones colectivas de la sociedad. Se trata de configuraciones administrativas territoriales o comunitarias locales que generan negociaciones y acuerdos colectivos entre sus habitantes para administrar y hacer sostenibles recursos naturales o territorios de los cuales dependen.

Pública, pero igualmente, a la fecha es imposible comprender la acción de las organizaciones públicas sin el componente de las políticas públicas que les imprime las directrices por las cuales debe orientarse y responsabilizarse. 
Lo evidenciado por parte de comunidades indígenas, afro descendientes o campesinas también niegan la existencia en exclusiva de una administración pública estatal.Esto, porque ellas generan sus propios procesos de organización comunitaria y ancestral de sus territorios, y que tienen la particularidad de romper con el modelo racional, burocrático y jerárquico de administración estatal al que se ha acostumbrado occidente. Igualmente, con los procesos de globalización, se divisan administraciones y burocracias públicas internacionales y transnacionales que dan lugar a administraciones públicas no estatales y no nacionales (Sassen, 2006). Un ejemplo es la Comunidad Económica Europea que aunque en articulación con las administraciones estatales, tiene sus propias lógicas, rutinas y racionalidades.

Todas estas evidencias apuntan a decir que el estudio de la Administración Pública como disciplina científica y social no puede limitarse al estudio de los elementos articulados alrededor del Estado en Acción y sus diversos componentes. También debe ocuparse de otras configuraciones que no se enmarcan en lo estatal. Sin embargo, debe reconocerse que es la de tipo estatal la que domina y abarca la mayor y más importante parte del fenómeno administrativo público moderno y contemporáneo.

\section{Comentarios finales}

El recorrido realizado en este capítulo alrededor de diferentes pensadores, temas y trabajos permite afirmar que al momento actual existe entre las ciencias sociales una disciplina científica y social con importantes preocupaciones, problemas y desafios: la Administración Pública. Esta, desde siglos atrás ha venido haciendo aportes a cómo pensar y proyectar la estructuración, cohesión y conducción de las sociedades por efecto de la acción administrativa. El estudio de la Administración Pública aunque verse sobre nociones y realidades que pueden llegar a aparecer como especializadas, técnicas y abstractas, lo cierto es, que terminan por definir cuestiones fundamentales para el destino de las personas a nivel individual y colectivo.

Ocuparse de la administración pública es un asunto estratégico que debe tener una importancia central en las agendas públicas de ciudadanos, gobernantes, especialistas y líderes públicos. De las creaciones administrativas que se ocupa el estudio de la Administración Pública, termina por depender: el reconocimiento y satisfacción de las necesidades de la población; la eficaz, oportuna y equitativa resolución a sus requerimientos y demandas; su acceso a servicios públicos (agua potable, alcantarillado, energía, gas, etc.); su disfrute 
de servicios sociales (salud, educación, empleo, protección a la infancia); su disponibilidad de infraestructuras viales, comunicacionales y urbanísticos; el reconocimiento y garantía de sus derechos e identidades colectivas; el desarrollo productivo y social de sus territorios.

El escenario ideal del desarrollo de esta disciplina es contar con el apoyo de otras ciencias como la política, la sociología, la antropología, y el derecho, para que aprovechando sus utillajes interpretativos, conceptuales y metodológicos, pueda lograr explicar y proyectar con integralidad sus objetos de estudio. No obstante, debe serle claro que otras disciplinas sociales aunque contribuyan, no pueden reemplazarla en el estudio de sus particulares objetos, preocupaciones y problemas. Como se pudo ver en el recorrido realizado en este capítulo, otra fue la época, ya superada, en donde se consideraba que ella podía reducirse a esperar y alimentarse de los desarrollos de otras disciplinas. 


\section{LA DEMOCRATIZACIÓN DE LA ADMINISTRACIÓN PÚBLICA}

\section{La problematización de la administración pública desde la democracia}

Aunque mucho se discute sobre las democracias contemporáneas en relación con sus procesos y actores políticos, poco se hace respecto a la importancia cumplida por las administraciones públicas en su papel de servirles de soporte. Resulta incuestionable que los sistemas políticos actuales no pueden sobrevivir a lo largo del tiempo sin la existencia de unos aparatos administrativos robustos que transformen sus principios y compromisos políticos en bienes, servicios y protecciones para los ciudadanos. Hoy por hoy, su importancia se expresa en que los Estados y sus gobiernos juegan su legitimidad y aceptación no sólo por las plataformas ideológicas y los compromisos políticos consignados en sus constituciones y leyes, sino también, por el acceso y la calidad de sus prestaciones públicas (Hamilton, 2007). Cada vez es más claro, que el bienestar colectivo de las sociedades no es sólo responsabilidad de los políticos o gobernantes elegidos, sino también, de las instituciones y autoridades administrativas que en el día a día hacen efectivo y materializan el vínculo político sostenido entre el Estado y la sociedad.

Hechos de distinta naturaleza en la actualidad invitan a interrogarse si las administraciones públicas sirven a las democracias, pero más que a estas, si lo hacen respecto a sus integrantes en condición de ciudadanos. Entre dichos hechos se encuentran:

- La ausencia de vocaciones del servicio público entre su personal.

- La demora o el mal trato en la atención.

- Los abusos de poder por parte de sus autoridades. 
- Los escándalos de corrupción de sus agentes.

- La exclusión de sectores de la población del disfrute de bienes y servicios.

- Los altos precios en las tarifas de los bienes y servicios públicos.

Situaciones como las mencionadas permiten interrogar si las administraciones están al servicio de los ciudadanos, o más bien, si estos son los que finalmente terminan por estar en función de ellas. La distancia cada vez más notoria entra la administración pública y la sociedad se expresa en que ella sea percibida en la actualidad entre una de las instituciones y de los agentes que gozan de mayor desprestigio entre la opinión pública. Por lo anterior, no es raro que a ella y sus agentes se les asocien a privilegios, desidia, demoras, ineficiencia, clientelismo y hasta corrupción.

La relación problemática entre democracia y administración pública no sólo está dada por lo que la ciudadanía espera y no llega a recibir de sus administraciones. Ella también se instaura en el obrar de quienes operan y son responsables del manejo del Estado, ya que en el día a día, tienen que lidiar con valores contradictorios articulados a racionalidades democráticas y burocráticas que organizan su accionar (Hamilton, 2007). Mientras unas, les exigen que promuevan la igualdad, las otras, les impulsan a promover la jerarquía; mientras unas, les estimulan a fomentar la participación colectiva en la toma de decisiones, las otras, les demanda limitarse a un pequeño número de expertos; mientras unas, les solicita que promuevan la equidad, las otras, les exige que consigan la eficiencia mediante la recuperación de costos. En términos generales, mientras las racionalidades de tipo democrático les exigen a los funcionarios lealtad con las constituciones políticas en sus propósitos y regulaciones democráticas, las de tipo burocrático, les demandan que respondan a los imperativos de eficiencia, eficacia y obediencia jerárquica con que se supone deben manejarse las organizaciones y procesos administrativos.

La cuestión de fondo es entonces si la democracia y la administración pública son terrenos separados, o pueden encontrar un espacio común donde puedan converger en propósitos y valores comunes. Para entender esta no convergencia entre una y otra, debe analizarse la forma en que se ha organizado la administración pública a lo largo del siglo XX, y desde allí divisar, qué aportes puede hacer un acento que llegue a enfatizar su íntima ligazón. 


\section{Del modelo burocrático a la Administración Democrática}

El modelo burocrático sería el paradigma que gobernaría la administración pública a lo largo del siglo XX. Su apuesta de un cuerpo de profesionales que hiciera frente a los asuntos públicos, sería un paso adelante en la tarea lograr que la fuerza de trabajo del Estado dejara de seleccionarse por recompensas políticas o reclutamientos patrimonialistas propio de las élites. En su lugar, el personal del Estado empezó a ser escogido por competencias y virtudes académicas certificadas (Fischer, 2009). Bajo sus principios de mérito, profesionalismo e impersonalismo, y bajo sus estructuras de división de trabajo y jerarquías administrativas, las estructuras burocráticas se convertirían en estrategias relativamente exitosas de dominación y conducción política de las sociedades modernas. En los países desarrollados, a todo lo lago del siglo XX, permitirían conducir con estabilidad y niveles de bienestar social a poblaciones integradas por millones de personas. En ese sentido, la administración pública y sus cuerpos de funcionarios se constituyeron en enormes y poderosas instituciones en las democracias modernas (Vigoda, 2002).

A pesar de su éxito, a lo largo del siglo XX la burocracia se convertiría en objeto de cuestionamientos por diversas razones (Cooper, 2015). Se les imputó a sus integrantes, el tener una manera estrecha de ver el mundo, ya que aunque contaban con competencias técnicas, no parecían tener las capacidades necesarias para ver el marco social y las implicaciones éticas que traían consigo sus acciones. Se les criticó que, por su confianza en los expertos, terminaban por relegar los aportes que podían hacer los ciudadanos respecto a encontrar las mejores alternativas públicas a problemáticas vividas. Igualmente se les cuestionó, su actitud de defender sus propias prerrogativas antes que hallarse interesados en proteger los intereses del público en general. Además, se les divisó cada vez más comprometidos con los intereses de las élites, que los hacia ver menos como promotores de la democracia, y más, como portadores y perpetuadores de injusticias (Fischer, 2009). Dichas críticas lograron su punto cumbre al presenciarse los cada vez más frecuentes escándalos de corrupción protagonizada por agentes y directivos del Estado.

Para hacer frente a dichas críticas, se propondría el robustecimiento de los valores y prácticas democráticas al interior de las administraciones públicas. Desde esta propuesta, los funcionarios debían ser entrenados y sensibilizados, no sólo en habilidades técnicas, sino también, en principios que los conectara y los pusiera al servicio de los ciudadanos. El tránsito y puente articulador 
entre las administraciones públicas y las democracias, serían por lo tanto, los ciudadanos. Al respecto de la íntima relación de los administradores públicos con la democracia, vale la pena traer lo señalado por dos autores que se ocuparon del tema. Roberth Denhart señalaría que:

"[...] los servidores públicos no prestan un servicio al cliente; ellos prestan democracia” (Mary Hamilton, 2007, p.16).

Mientras que Terry Cooper diría que:

“(...) un administrador público es un ciudadano que es empleado para trabajar a favor de nosotros; una especie de ciudadano profesional contratado para hacer el trabajo que en un complejo de gran escala como lo es la comunidad política somos incapaces de emprender por sí mismos" (Mary Hamilton, 2007, p.16).

Lo señalado por los autores citados dan para afirmar que los agentes que operan el Estado deben asumir que su trabajo no es solamente técnico, sino también, ético y político.Ético, porque su condición es la de ser un ciudadano que es investido de confianza por parte del pleno de la ciudadanía para que haga cosas a nombre suyo y a su favor. Político, porque su compromiso es hacer las cosas en función de materializar la democracia y el interés general. En este marco ético y político, los funcionarios públicos serían no sólo responsables por lograr que exista eficiencia y eficacia en las organizaciones y políticas públicas, sino también, que se materialicen los valores y propósitos de la democracia a la que sirven; y con ello, que los ciudadanos accedan y materialicen sus derechos mediante los servicios y bienes prestados por intermedio de ellos.

Otra propuesta asumida como un remedio contra unas administraciones públicas desenvueltas de espalda a los ciudadanos, estaría dada por la búsqueda de combinar el modelo de democracia representativa tradicional con otra nueva de tipo participativo. Si bajo el modelo representativo correspondía sólo a las autoridades electas el velar porque la voluntad de la población quedara expresada en las actuaciones del Estado, con el advenimiento del segundo modelo también sería responsabilidad de las burocracias y de los servidores públicos. En este otro modelo, los ciudadanos ya no sólo son requeridos para que cada cierto tiempo alimenten la democracia con sus votos, sino también, porque se espera de ellos que hagan parte activa y permanente en las políticas públicas y en las administraciones públicas. Igualmente, para que hagan control social de las actuaciones de directivos y funcionarios del Estado. 
Con el advenimiento de las democracias participativas, se abre el camino para interrogar qué posibilidades y qué capacidades podría aportar la ciudadanía y su participación al mejor desempeño y rendimiento de las administraciones públicas. En términos estrictamente técnicos, la participación puede verse como una fórmula que podía ayudar a los encargados o directivos del sector público a monitorear y alertar sobre el desperdicio, el fraude o el abuso en las decisiones y recursos públicos. Igualmente, puede proveer información para que dichos recursos se distribuyan más a fin con las necesidades y demandas de la sociedad, al turno que, puede ayudar para que los proyectos e intervenciones públicas hechas en la sociedad se vuelvan más sostenibles al identificarse con ellas los ciudadanos. Si bien mediante las justas electorales estos últimos pueden designar unas cabezas del gobierno, hacerlo no es suficiente ya que no les permite dar guía a asuntos específicos; precisamente, este vacío pretende ser llenado mediante su participación (Aimee, 2007).

Son muchos los posibles beneficios que puede traer la participación ciudadana para el sector público. Aunque así lo sea, su propuesta no deja de causar resistencias entre quienes fueron educados bajo los axiomas y las creencias del paradigma burocrático, ya que bajo este, se asumió que en las administraciones públicas hay cuestiones estrictamente técnicas que deben ser protegidas de la injerencia de la democracia. Un área administrativa donde sin duda se divisa de forma más evidente este prejuicio, es el de presupuesto, al considerarse que se trata de un asunto técnico por estar asociado a cálculos, formatos y balances. Bajo dicho supuesto, históricamente se pretendió derivar que, su formulación debía quedar exclusivamente en manos de expertos profesionales. Sin embargo, perspectivas o enfoques recientes señalan que las cuestiones técnicas no son diferentes de las de naturaleza política (Franklin, 2007). En el caso del presupuesto, por más que deba operativizarse a través de acciones técnicas, es también un proceso político.Y lo es, porque involucra decisiones donde se define quiénes deben pagar y quiénes deben recibir unos beneficios de parte del gobierno. En el entendido que se trata de un proceso político, y más allá, democrático, hoy por hoy se avanza en muchas ciudades del mundo en hacer presupuestos con participación ciudadana (Hábitat, 2007).

La resistencia a la participación ciudadana en la administración pública no solamente proviene de las rigideces mentales construidas a partir del paradigma burocrático, sino también, porque toda innovación requiere un trabajo de aprendizajes, pero también, de des-aprendizajes. La cuestión pasa entonces en cómo aprender a construir de manera efectiva una participación 
pública y/o participación ciudadana en el seno de las instituciones y de la sociedad, pero también, en cómo dejar atrás otras prácticas que desde antaño se han opuesto a la misma. Este desafio, para ser superado, puede apoyarse en diversos estudios que se han venido produciendo desde instituciones universitarias y organismos internacionales. Literatura de expertos y de académicos cada vez más apuntan a plantear estrategias, técnicas y prácticas específicas para impulsar y desarrollar la incidencia y participación ciudadana (Creighton, 2010), (Smith, 2010), (Habitat, 2007), (Callahan, 2007). El siguiente cuadro recoge los potenciales aprendizajes que pueden adquirirse en diversos textos especializados.

\begin{tabular}{|c|c|c|}
\hline \multicolumn{2}{|c|}{ POTENCIALES APRENDIZAJES RESPECTO LA } \\
PARTICIPACIÓN \\
\hline $\begin{array}{c}\text { Cómo planear e } \\
\text { implementar la } \\
\text { participación }\end{array}$ & $\begin{array}{c}\text { Cómo proveer y recoger } \\
\text { información de los } \\
\text { ciudadanos }\end{array}$ & Cómo hacer encuentros públicos \\
\hline $\begin{array}{c}\text { Cómo trabajar con medios } \\
\text { electrónicos }\end{array}$ & $\begin{array}{c}\text { Cómo llevar a cabo una } \\
\text { rendición de cuentas }\end{array}$ & $\begin{array}{c}\text { Cómo construir procesos de } \\
\text { planeación participativa }\end{array}$ \\
\hline $\begin{array}{c}\text { Cómo intervenir } \\
\text { comunidades y trabajar con } \\
\text { grupos }\end{array}$ & $\begin{array}{c}\text { Cómo propiciar la } \\
\text { participación mediante } \\
\text { redes virtuales y } \\
\text { mecanismos electrónicos. }\end{array}$ & $\begin{array}{c}\text { Cómo construir presupuestos } \\
\text { participativos }\end{array}$ \\
\hline
\end{tabular}

\section{La democratización de la administración pública en América Latina ${ }^{12}$}

En América Latina la gestión pública democrática como corriente de pensamiento y propuesta de reforma del Estado se constituirá en la reacción de un grupo de pensadores latinoaméricanos al modelo dominante de reforma del Estado, concebida esta, como búsqueda exclusiva de racionalidad económica y administrativa. En el año de 1995, el Consejo Científico del CLAD (Centro Latinoamericano de Administración para el Desarrollo) publica el documento titulado Una Nueva Gestión Pública para América Latina. En él, señalan que si bien una de las preocupaciones del Estado en América Latina es la del crecimiento económico, también lo son, las referidas al mejoramiento en la distribución de la riqueza y la consolidación de la democracia (Pereira, 1998). Al entender de los creadores del CLAD,

12 Este ítem recoge una parte del texto presentado a la I Cátedra Internacional de Administración Pública de la ESAP. 2013. Ponencia Gestión Pública Democrática. Una corriente alternativa de pensamiento y de reforma administrativa del Estado. 
si bien debe buscarse aumentar la eficiencia y efectividad del Estado, uno y otro objetivo deben supeditarse a lograr el desarrollo económico y social bajo las riendas de la democracia. En su concepción, en América Latina no se trata de crear un Estado más eficiente y efectivo, sino, uno verdaderamente democrático que lleva a que sea la voluntad popular la que prevalezca sobre cualquier tipo de consideración técnica. Inspirada en dichos principios, el CLAD propuso una serie de estrategias que enfatizaban en la democratización para reformar el Estado.

La primera estrategia que lanzaron, invita a generar una redefinición de las relaciones entre Estado y sociedad, en donde se promueva la construcción de esferas públicas que involucre a los ciudadanos en la gestión de las políticas públicas. La segunda, pasa por la responsabilidad política de las cabezas administrativas, las cuáles deben comparecer a rendir cuentas ante representantes de la sociedad civil y políticos electos, e igualmente, velar porque la administración pública se vuelva más transparente y volcada a la rendición de cuentas. La tercera, invita a la descentralización de los niveles nacionales del Estado, para que, al trasladarse sus funciones al nivel local aumente no solo la eficacia y eficiencia, sino también, la interlocución con la ciudadanía. Una última estrategia está dada por el control social ejercido por la ciudadanía respecto al poder público, el cual permitiría evaluar los servicios públicos o la gestión que prestan las administraciones públicas.

Los integrantes del comité científico del CLAD coincidirán en hacer una crítica al modelo burocrático de administración por centrar su énfasis solamente en las reglas y en los procedimientos, y no también, en la eficacia y eficiencia de sus acciones. Apuntan a que debe de tenerse en cuenta las especificidades de la Región para con ello acotar y entender el sentido de sus propuestas y formulaciones. En ese marco, dicen que sus críticas se centran en el carácter burocrático que asumieron las administraciones en América Latina y no en la profesionalización del cuerpo de funcionarios, aspecto central de la propuesta Weberiana. A su entender, uno de los retos es que ninguno de sus países logró profesionalizar su personal, y con ello, completar la construcción de unas estructuras administrativas, cuestión esta que si aconteció en los países desarrollados. Reconocen los integrantes del comité científico del CLAD, que la profesionalización de la burocracia en la Región ha aportado al evitar que por vía del saber técnico y del mérito que la administración pública fuera capturada por parte de los políticos. Sin embargo, dado que la burocracia no era totalmente inmune a la corrupción, fenómeno éste que estaba en aumento en América Latina, su control 
democrático se hacía necesario. En su perspectiva, debía entonces llevarse a cabo una modernización del sector público teniendo en cuenta aquellos ingredientes que el paradigma de la administración pública burocrática no tenía, tales como lo eran, la eficiencia, la flexibilización y la democratización del servicio público.

Dicho documento conducente a proponer una nueva gestión para América Latina, haría las veces de una declaración de principios, y que en su construcción, se soportaría en reflexiones que venían haciendo autores de diversos países articulados en torno al CLAD. Uno de ellos, Nuría Cunill, entendió que la modernización del Estado en América Latina en las décadas de los 80's y 90's, se articuló a los procesos de globalización y de ajuste fiscal, que llevaron a asumirla desvinculada de las necesidades sociales de la población y a entenderla como un proceso de recorte y desmonte del Estado (Cunill, 1997). Alude a los casos de México, Argentina y Perú como paradigmáticos, ya que muestran como la modernización se había asumido en dichos países básicamente como la privatización de las empresas prestadoras de servicios públicos, así como, recorte del gasto social.

Dado que la reforma administrativa en la Región fue auto referencial y con ausencia de responsabilidad pública, para Cunill, debía sustituirse por otra donde la sociedad resultara favorecida e incidiera en su orientación. En este sentido, en lugar de un desmonte indiscriminado del Estado se requería un fortalecimiento del mismo que fuera soportado en fundamentos democráticos. En este contexto, es que hace aparición su propuesta de democratización de la gestión pública, acorde a la cual, debe constituirse la ciudadanía como un actor estratégico; esta, mediante su presión o incidencia, puede asegurar la eficiencia de las actividades de la administración y los avances en la profesionalización de su burocracia. Desde su perspectiva, se trata de que la participación ciudadana contrabalancee el poder de la burocracia, para lo cual, debe contar con los medios necesarios para influir en ella y en las políticas que maneja (Cunill, 2003) Al entender de Cunill, esto podía remediarse mediante un fortalecimiento de la esfera pública mediadora entre el Estado y la sociedad.

Al igual que Cunill, otros pensadores hicieron parte de esta especie de tanque de pensamiento latinoamericano del CLAD que durante finales de la década de los noventa decidieron posicionar una nueva perspectiva para la reforma del Estado. (Bresser, 1998), (Bresser, 2001), (Garnier, 1997), (Garnier, 2005). En 2009, el Comité científico del CLAD en compañía de 
un grupo mayor de intelectuales elaboraron una declaración de principios llamada la "Carta Iberoamericana de Participación Ciudadana en la Gestión Pública" la cual sería adoptada por los jefes encargados de la reforma y de la modernización en 17 países (CLAD, 2009) ${ }^{13}$. Esta, delinearía el núcleo duro de la propuesta realizada por la corriente intelectual y de reforma jalonada por el CLAD en relación a la gestión pública democrática. La misma, fue un importante logro político al lograr que sus reflexiones y propuestas fueran acogidas por los Estados de la Región.

La Carta, inicia señalando que busca avanzar en la consolidación de una democracia plena, para lo cual, debe de procederse a democratizar la gestión pública a través de establecer el derecho de participación ciudadana en la gestión pública. Dicho derecho, es uno de tipo activo y exigible a los poderes públicos, que para garantizarlo, es recomendable su constitucionalización en los ordenamientos jurídicos. Con lo anterior, busca garantizarse al ciudadano intervenir en diversos campos de la gestión pública referidos ellos a las políticas públicas, los programas sociales, los servicios públicos, los recursos públicos y la información pública etc. La Carta define la participación ciudadana como:

El proceso de construcción social de políticas públicas, que conforma el interés general de la sociedad democrática, canaliza, da respuesta o amplía los derechos económicos, sociales, culturales, políticos y civiles de las personas, y los derechos de las organizaciones o grupos en que se integran, así como los de las comunidades y pueblos indígenas. (CLAD, 2009, p.5).

La Carta enfatiza en que la participación debe ser continua y transversal a la actuación de los poderes públicos, debe trascender las esferas públicas locales para llegar a consolidarse en el nivel nacional y debe darse en todas las etapas de las políticas públicas. Una de las condiciones esenciales para que avance la participación en la gestión pública, es que los órganos públicos, así como los particulares con responsabilidades públicas, sean sensibles y receptivos a las opiniones y propuestas realizadas por la sociedad. Indica la Carta que las "administraciones públicas incorporarán a su agenda de decisiones las perspectivas y las alternativas producidas por los procesos participativos", aunque resguardando la discrecionalidad que les atañe a los encargados de dirigir las políticas.

13 Esta fue aprobada por la XI Conferencia Iberoamericana de Ministros de Administración Pública y Reforma del Estado en Lisboa, Portugal, 25 y 26 de junio de 2009 y fue adoptada por la XIX Cumbre Iberoamericana de Jefes de Estado y de Gobierno en Estoril, Portugal, 30 de noviembre y $1^{\circ}$ de diciembre de 2009. 
Para salvaguardar la participación en la gestión pública, alude la Carta a que debe garantizarse cauces institucionales y recursos financieros que la posibiliten, e igualmente, debe establecerse procesos de formación, información y sensibilización dirigidos a la ciudadanía y a los servidores públicos. Suma a lo anterior, la rendición de cuentas y la transparencia como principios que deben orientar la relación entre la administración pública y los ciudadanos. Para lograr la participación en la gestión pública, además, debe garantizarse el acceso y la difusión de información pública, y para ello, indica la plataforma del CLAD, que debe avanzarse en crear canales de comunicación en cada sector y eliminar requisitos para su adquisición.

Dejando de lado los planteamientos específicos del CLAD, puede decirse que la gestión pública democrática no sólo se constituye en una propuesta que aboga por la repolitización democrática del Estado y su gestión pública, sino debe asumírsele también, como una estrategia que busca superar problemas de deterioro de lo público por efecto de fenómenos tales como el clientelismo, la corrupción, el burocratismo o el elitismo. Al ser la democracia subversiva, en el sentido que tiende a romper todas las relaciones de dominación y dependencia, y al alterar la premisa según la cual el poder viene de arriba hacia abajo, lo que trata de hacer con ella es generar condiciones positivas para situar el poder público al servicio del conjunto de la población (Harris, 2000). Como lo plantea Richard Harris (2000), si la democracia primero permitió enfrentar a la aristocracia contra el poder monárquico, luego a la burguesía contra la aristocracia, posteriormente a las masas populares contra la burguesía, hoy por hoy, podría permitir a la ciudadanía enfrentar a las élites políticas, administrativas o económicas que capturan y privatizan los recursos y decisiones públicas. Por ese camino, se propone que la participación ciudadana y el control social contrabalancee el poder de burocracias, élites y oligarquías, para lo cual, debe contar con los medios institucionales necesarios para lograrlo (Cunill, 2003).

Frente a la captura del Estado, la democratización de la administración pública plantea como posible camino el paso de una concepción Estadocéntrica a otra de carácter público. Desde ésta última, al ser público el Estado, su definición y construcción no debe ser monopolio de los gobiernos, los funcionarios o los partidos políticos, sino también, es potestad y responsabilidad del conjunto de los ciudadanos. En la perspectiva de la democratización de la administración pública, son los ciudadanos quienes tienen el derecho y el deber de intervenir el mundo administrativo al ser los titulares de la soberanía popular, y por ende, ser los destinatarios naturales del poder público. Para lograr la prolongación de su soberanía, se hace necesario 
la creación de espacios públicos al interior de los aparatos administrativos que traigan consigo una acción pública producto de los consensos y disensos entre actores del Estado y el público ciudadano (Uvalle, 2005).

Crear esferas públicas se vuelve relevante no sólo para decidir la apropiación de recursos o la definición de objetivos públicos que afectan al conjunto de la población, sino también, para aquellas negociaciones sostenidas por parte del Estado con contratistas y empresarios encargados de proveer bienes, infraestructuras y/o servicios públicos. En términos de la gestión pública democrática, uno de los problemas centrales está dado por cómo las alianzas público/privadas permiten o no la generación de valor público para el conjunto de la ciudadanía (Moore, 2006). Apunta la propuesta entonces, a que el papel cumplido y los beneficios obtenidos por los actores privados en relación con el sector público han de ser establecidos no sólo porque lo consideren conveniente las autoridades estatales en correspondencia con los empresarios, sino también, por lo que consideran los ciudadanos. Si es a la ciudadanía a la que corresponde financiar los recursos públicos que terminan por llegar a manos de los privados, resulta razonable que se posibilite su participación y que se garantice criterios democráticos que guíen las negociaciones del Estado con los privados. Dicho ejercicio puede ayudar a instaurar una nueva cultura y comprensión de lo público/privado, donde se observa que ni al mercado le es posible actuar sin el Estado, así como a éste, tampoco le es posible lograrlo sin las energías aportadas por aquel pero bajo el control de la ciudadanía(Uvalle, 2005).

Una de las virtudes de la democratización de la gestión pública es que con ella puede contrabalancearse el poder de los grupos que capturan al Estado. Sin embargo, cuenta con otras importantes virtudes que se pueden ilustrar tomando como referencia las reflexiones de Bernardo Kligsberg (2007) quien busca interrogar acerca de cómo la participación puede ayudar a corregir la desigualdad en las sociedades. Al respecto, señala el autor que, el panorama de pobreza en América Latina no es alentador ya que mientras en la década de los 80’s había 146 millones de pobres, en la primera década del siglo XXI (2005), ya llegaban a los 228 millones (pasando los pobres extremos de 60 a 94 millones). Sumaba a esta cifra, el dato que en América Latina los niveles en la concentración de la riqueza eran los más altos del mundo, siendo sus sociedades, las más desiguales. Tales índices para Kligsberg daban cuenta de una elevada exclusión social que creó un "volcán” social de altas tensiones, pérdida de cohesión social y la remoción de más de 14 mandatarios. A su entender, en América Latina ya eran inadmisibles estos niveles de desigualdad. 
Le llama la atención a Kligsberg que a la par del crecimiento de dicha desigualdad en América Latina, observa también sociedades civiles articuladas y más activas que presionan por la transparencia de los procesos electorales, por mejorar la representatividad de los liderazgos políticos y porque se establezcan canales para que rindan cuentas sus gobernantes. A su entender, la sociedad está superando la visión economicista ortodoxa de reducir el Estado y confiar todo al mercado, para avanzar más bien, en una cooperación entre un Estado capaz con sensibilidad social, unas empresas responsables y una sociedad civil plenamente movilizada. El punto central en su perspectiva es que las opciones políticas que le han apostado a la participación ciudadana efectivamente han incidido en la reducción de la desigualdad, y de allí que afirme, que en varios países "la participación ha impulsado y protegido los procesos de cambio, ha equilibrado la sociedad, ha llevado a reducir la pobreza" (Kligsberg, 2007, p. 49). Las experiencias como la de Porto Alegre en Brasil,Villa del Salvador en Perú y Rosario en Argentina, evidenciaron que "la participación se mostró como una estrategia maestra para reducir la desigualdad", dado que corrigieron "los profundos desequilibrios de poder económico, discriminación y asimetría política, desaparecieron al interior de las experiencias por la integración igualitaria a través de la participación".

\section{Comentarios finales}

Es cada vez más clara, expresa y directa la articulación que se busca entre la realidad institucional de la administración pública y la de la democracia. Históricamente ésta última se instituyó cómo aquel régimen y sistema que sustentó su legitimidad en que el poder del Estado debía servir y estar en función de los ciudadanos. Con ella, se erigió la posibilidad de que el poder público ya no estuviera en función del príncipe, el rey o la a nobleza, sino también, que estuviera en función de proporciones cada vez más amplias de la población. Con la democracia los pobladores dejaron de ser súbditos para convertirse en ciudadanos, cuestión que en adelante, los convirtió en titulares del poder político del Estado. El arreglo con que se lograría instituir la democracia a lo largo del siglo XIX y primera mitad del XX, sería la democracia representativa mediante la elección de representantes y la delegación de su titularidad política en ellos. Para lograrlo, se instauró, entre otros, el voto popular, los cargos de elección popular, los sistemas electorales, los partidos políticos y los derechos de diferente tipo como los referidos a la libre asociación y a la libre opinión. 
No obstante, en la última mitad del siglo XX y las primeras décadas del siglo XXI se exige que la democracia vaya más allá de permitirles a los ciudadanos de elegir mediante voto popular a unos representantes. Por ese camino, se presiona para que el Estado, su gobierno y su administración se abran a la participación de la ciudadanía para que incida en las decisiones del Estado y tenga control de los procesos políticos-administrativos que se desarrollan a su interior.Ya no era suficiente que la democracia se limitara a un asunto de votaciones y representantes políticos sino que debía de ampliarse para que se posicionara al interior del mundo de la administración pública. Se pide que ella se haga realidad en sus organizaciones públicas, sus políticas públicas, sus procesos de gestión y sus relaciones Estado y sociedad, entre otros. Por ese camino, se busca democratizar sus estructuras y gestión mediante la apuesta de que el ciudadano y sus derechos aparezcan como el centro y referente de su accionar. Bajo dicha apuesta, ya no es suficiente que los agentes de la administración pública legitimen su actuación en principios como la legalidad, la eficacia o la eficiencia, sino también, en otros tales como el servicio al ciudadano, la garantía de derechos, la participación ciudadana, la responsabilidad y la rendición de cuentas.

Como se evidenció a lo largo de éste capítulo, un principio interesante que empezó a acuñarse en América Latina para democratizar la administración pública fue el derecho a la "participación en la gestión pública". Dicho derecho, expresa una apuesta por abrir y situar a la administración pública en función de la ciudadanía, abriéndola a su influencia y control. Bajo este, se empezó a promover el derecho que deben tener los ciudadanos para participar activamente en la construcción de las políticas públicas en sus distintas fases, al igual que, en los diferentes procesos institucionales de la administración pública. El propósito de dicha participación es que diferentes grupos de ciudadanos puedan contar con canales y recursos para garantizar y materializar sus derechos.

Además, la democratización de la administración pública pretendía que el poder del Estado se asegurara de ser público y dejara de ser privado. Como lo mencionó Nuria Cunill, se trataba de que la ciudadanía contrabalanceara el poder de las élites, los políticos y las burocracias que habían capturado el poder y los recursos del Estado. Con el poder ciudadano se abría un camino que permitía combatir o solucionar distintos males que vivían las instituciones y sus encargados. Con la apertura a los ciudadanos por parte de las administraciones públicas se esperaba corregir otras falencias que se empezaban a divisar entre el personal administrativo, entre las cuales se 
contaba, la manera estrecha con que veían el mundo y el relegamiento que hacían de los intereses de la población.

El recorrido realizado en este capítulo permitió evidenciar también cómo el poder de la ciudadanía al operar al interior de la administración pública puede permitirle logar su vocación pública y democrática. Un elemento fundamental es que ella debe propiciarse no solo en una u otra institución sino en el conjunto del Estado, lo anterior, bajo el tópico de la Reforma del Estado. Es así que, sus promotores situados en determinado contextos históricos de transformación del Estado en América Latina, apuestan a que si la reforma ha de realizarse debe apuntar a garantizar no sólo el crecimiento económico o la eficiencia, sino ante todo, la democracia y estar al servicio de la ciudadanía. Por este camino, la reforma aparece inspirada por otros valores tales como la igualdad, la inclusión y la participación, entre otros. Más elementos se suman a ellos, tales como lo son la integridad, la transparencia y la responsabilidad, al igual que, la cooperación, el diálogo y la concertación.

Que la democracia ahora deba cultivarse y crecer al interior de las administraciones públicas, o igualmente, que el poder ciudadano deba asumirse como una nueva variable y principio de la gestión pública, no es una cuestión fácil de realizar y asumir en el corto plazo. Debe avanzarse, no sólo en crear diseños institucionales donde se abran espacios para la participación activa de la ciudadanía, la rendición de cuentas y la transparencia, sino también, en crear culturas administrativas que asimilen este otro paradigma. Un desafío es cambiar las mentalidades de dirigencias, directivas y funcionarios educados bajo concepciones elitistas o burocráticas, que en no pocos casos, los lleva a desconfiar, subestimar e irrespetar a los ciudadanos a nivel individual y colectivo.

Dicho aprendizaje no es fácil para los responsables y operadores del Estado y la administración pública. Ellos deben de tramitar conflictos y lidiar con racionalidades de distinta naturaleza que les exigen cosas distintas que no siempre son fáciles o posibles de conciliar. Como ya se mencionaba en uno de los apartados, los administradores de lo público deben resolver dilemas del siguiente tipo: mientras la racionalidad democrática les exige que promuevan la igualdad, la de corte administrativa les empuja a respetar la jerarquía; mientras la racionalidad democrática le impulsa a fomentar la participación colectiva en la toma de decisiones, la de tipo administrativo les demanda limitarse al concepto propio y al de los expertos; mientras la racionalidad democrática les solicita que promuevan la equidad, la administrativa les exige basarse en el criterio de la eficiencia preocupada por los costos y los resultados. 


\section{III}

\section{LAS TECNOLOGÍAS DE LA INFORMACIÓN Y DE LA COMUNICACIÓN (TIC) APLICADAS AL SECTOR PÚBLICO}

\section{Situación de las TIC en el sector público}

En el sector público se ha reportado un uso creciente de las TIC para responder a propósitos diferentes relacionados con la gestión, los servicios y las relaciones con los ciudadanos. La expansión e importancia cobrada por el uso de las tecnologías en el sector público se expresa en algunos indicadores. Para los primeros años del siglo XXI, existían más de 50.000 páginas web gubernamentales y casi 100 países contaban con sitios de Internet para ofrecer información y prestar servicios a los ciudadanos (Kamarck, 2003). En el 2012, los países pertenecientes a la Unión Europea ya habían alcanzado tasas del 32\% en gobierno electrónico, mientras que los adscritos a la OCDE habían alcanzado tasas del 40\% (Naciones Unidas, 2012). En dicho año igualmente, en 55 países ya se podía tramitar y obtener documentos de identidad, certificados de nacimiento o licencias de conducción, mientras que en 77 se había abierto la posibilidad de pagar impuestos mediante mecanismos electrónicos. Finalmente, en el año en cuestión, ya habían dado 18 países pasos para habilitar las redes electrónicas que permitieran la votación electrónica a sus ciudadanos.

No todos los países del globo han llevado los mismos ritmos ni alcances respecto a la incorporación, uso y expansión de las TIC. Países anglosajones, europeos y algunos asiáticos suelen estar en la delantera en cuanto a su adopción, mientras los países de otros continentes suelen estar a la zaga. Para la primera década del siglo XXI un 60\% de los pobladores de los países desarrollados poseían acceso a ellas, en tanto en los clasificados como en vías de desarrollo, sólo un 16\% lo lograban hacer (Naciones Unidas, 2011). La baja coberturas en los últimos, se atribuían a factores tales como la insuficiencia de recursos, la inadecuada infraestructura, el déficit de educación y la débil conectividad. En todo caso, hay países que sin pertenecer al conjunto de 
los desarrollados llegaron a ocupar similares escalafones en lo referente a la adopción y uso de ellas. Un ejemplo es Colombia, que se ubicó en el sexto lugar al lado de Finlandia y Japón; o la República de Corea y Singapur, que en servicios en línea ocuparon el mismo primer lugar de los Estados Unidos de América (Naciones Unidas, 2011).

Organizaciones como Naciones Unidas -ONU- han hecho pronunciamientos y compromisos en relación con las TIC. En el 2011, ellas se volverían objeto de declaraciones de sus gobiernos y Estados miembros al considerar que por medio suyo se podía promover el crecimiento, el desarrollo, la competitividad, el acceso a la información y el conocimiento. La relevancia otorgada por Naciones Unidas quedaría plasmada en su iniciativa de recoger desde el año 2003 las experiencias de los Estados respecto a la adopción de los usos innovadores de ellas. Se vería plasmada también en su División de Administración Pública y Desarrollo, la cual se constituyó en el soporte técnico para reflexionar y promover el uso de la TIC a nivel mundial, al igual que, para adoptar agendas que impulsaran su uso.

A la importancia cobrada por las TIC le ha acompañado un amplio discurso que enaltece sus potencialidades y ventajas en relación a los desempeños del Estado. Al respecto de cómo las TIC pueden mejorar los servicios prestados por el sector público se divisa varias posibilidades. Entre ellas se encuentran: el pago de impuestos, multas o servicios públicos en línea; la expedición electrónica de documentos de identidad o de extranjería; la autorización y cancelación de licencias de distinto tipo como las de conducción, industria y/o comercio; la provisión de información cultural, educativa y de transportes (Bredschneider, 2015). Es así que procesos que en otros momentos exigían un gran gasto de esfuerzos y recursos para ser llevados a cabo, gracias a las TIC, se han transformado radicalmente. Un buen caso es el manejo de los expedientes de los millones de ciudadanos asociados a los sistemas de salud o de seguridad social, los cuales gracias a las TIC, ya no requerían de un número de personal significativo para ubicarlos, de tiempos prolongados para hallarlos, tampoco de equipos extensos para clasificarlos y analizarlos; menos aún, de bodegas enteras para archivarlos.

Las TIC traen como potencialidades el contribuir a edificar administraciones públicas más integras, transparentes y eficientes. En relación con las dos primeras potencialidades, se menciona la importancia que puede tener la publicación en línea de los planes, presupuestos y contratos de las entidades, o la consulta electrónica de decisiones y regulaciones adelantadas por las 
instituciones, o igualmente, la publicación de los términos y de los pliegos de contrataciones y de concursos públicos. En ese marco, las TIC permiten visibilizar las actuaciones del Estado, al igual que, facilitan la labor de control social que quieran y puedan desarrollar los ciudadanos. Respecto a la eficiencia, se encuentran diversos sistemas electrónicos que agilizan y generan confianza en la realización de procesos y trámites al interior de las entidades del Estado y a nivel global del mismo. La potencia de ellos radican en que estandarizan, regularizan, automatizan los procesos al igual que permiten sistematizar, disponer y monitorear miles de interacciones realizadas cada día por las organizaciones. Algunas de las áreas donde las TIC vienen siendo utilizadas, se expresan en el cuadro siguiente.

\begin{tabular}{|c|c|c|}
\hline \multicolumn{2}{|c|}{ SISTEMAS ELECTRÓNICOS DE } \\
ADMINISTRACIÓN E INFORMACIÓN \\
\hline Presupuestales & Nóminas de personal. & Pagos \\
\hline Contratación & $\begin{array}{c}\text { Seguridad social de } \\
\text { empleados }\end{array}$ & Planeación \\
\hline Control de la ejecución & Beneficiaros y aportantes & Bienes y servición provistos \\
\hline Recaudo y manejo de carteras & Recursos Físicos & Georreferenciación \\
\hline Recaudo de Impuestos & Gerencia y Control & \\
\hline
\end{tabular}

Las potencialidades de las TIC van más allá de lo que ellas pueden brindar al manejo de las administraciones públicas o de los gobiernos. Hay que verlas igualmente del lado de las oportunidades que abren a los ciudadanos para lograr una mayor influencia en la vida pública (Franklin, 2007). Es evidente que, antes de la existencia masiva de los medios electrónicos las personas del común tenían que comunicarse de forma personal, individual y privada, bien fuera, con otros ciudadanos, o bien, con las instituciones gubernamentales. Ello implicaba, que los temas que eran objeto de su intercambio quedaran confinados a una comunicación privada a pesar de que en ocasiones sus contenidos pudieran llegar a ser materia de interés público. Gracias a herramientas informáticas tan sencillas como los correos electrónicos y las redes sociales, dicha situación se ve superada al lograrse comunicaciones no sólo fáciles y rápidas sino también masivas y públicas. Con las TIC, siempre 
hay la posibilidad de que inquietudes o reclamos frente al Estado se vuelvan causa común entre la población, o igualmente que, reivindicaciones que apuntan a proteger derechos sumen miles y hasta millones de apoyos con los cuales las administraciones y gobiernos se ven obligados a actuar frente a las mismas.

\section{El gobierno electrónico}

Uno de los campos donde más se ha referenciado el uso de las TIC en el sector público es lo que se ha llamado el gobierno electrónico o E-Goverment. Por este se entiende a los productos y a los procedimientos desplegados por los gobiernos para interactuar con sus destinatarios mediante el uso de las TIC, y que se pretenden, generen valor público (Rhoda, 2008). Es en los países desarrollados, donde se han llegado a alcanzar los estadios más avanzados o complejos de gobierno electrónico, aunque en países y regiones que no caen dentro de dicho rango, se vienen dando pasos para avanzar en relación con el tema. Un paso dado en América Latina se dio en el 2007 con ocasión de la XVII Cumbre Iberoamericana de Jefes de Estado y de Gobierno en donde se adoptó la "Carta Iberoamericana de Gobierno Electrónico".

En esta cumbre los mandatarios se comprometieron a usar las TIC para fortalecer los gobiernos y las administraciones públicas de sus países ${ }^{14}$. Al entender de sus líderes, las TIC podían generar mejoras en la transmisión de información, en los servicios ofrecidos, en la gestión pública, en la participación de los ciudadanos y en la transparencia del sector público. Entre los retos que veían los mandatarios y que expresaban en la Carta, estaban el cómo superar las brechas de acceso a las tecnologías en sus países, como también, en cómo universalizar la alfabetización tecnológica entre el conjunto de la población. Un reto grande estaba dado en cómo hacer para que el almacenamiento y las transacciones por medios electrónicos tuvieran la confiabilidad y seguridad necesarias.

Existen diferentes grados de adopción de tecnologías en relación con el gobierno electrónico. Un primer grado,refiere a la publicación de información generalmente realizada mediante tableros o links; un segundo grado, alude a las interacciones entre las entidades y sus usuarios a través de documentos, formularios o invitaciones hechas por instituciones del Estado; un tercer

14 Aprobada por la IX Conferencia de Ministros de Administración Pública y Reforma del Estado, dada en Chile en mayo-junio de 2007 y adoptada por la XVII Cumbre Iberoamericana de Jefes de Estado y de Gobierno en noviembre de 2007.p.7. 
grado, remite a las transacciones, realización de trámites o interacciones mediante servicios en línea, chats, foros o consultas electrónicas; un cuarto grado, describe a las interacciones relacionadas con votaciones, realización de licitaciones o concursos públicos a través de medios electrónicos (Anderson, 2015). El gobierno electrónico se ve organizado según tipos de interacción, que en su grado mínimo se expresan en la emisión unilateral de informaciones, mientras en los de grados mayores, habilitan transacciones bidireccionales entre agentes del Estado y los ciudadanos. Igualmente, unas interacciones precisan mayores grados de seguridad que otras por el valor diferencial que llegan a tener en términos políticos o económicos, entre ellos se cuentan, el voto electrónico, los contratos o licitaciones.

El gobierno electrónico también se organiza en función de los diferentes grupos o colectivos con que interactúa el Estado y sus administraciones públicas. En ese sentido, existe el relacionado con los negocios que abarca los dispositivos y redes informáticas que el gobierno y las administraciones públicas instauran para propiciar transacciones y comunicaciones con proveedores, contratistas y empresarios que ofertan y adquieren bienes y/o servicios. También existe el articulado a los empleados, que alude a los dispositivos y redes informáticas instauradas para soportar las relaciones entre el gobierno y sus trabajadores y en donde se desenvuelven procesos atinentes a su reclutamiento, ascenso, evaluación, entrenamiento y servicios. Se suma el gobierno de los ciudadanos que alude a las herramientas y redes electrónicas propiciadas y utilizadas por los gobiernos para informar o interactuar con ellos. Finalmente, está el alusivo a los gobiernos que refiere a los dispositivos y a las redes informáticas instauradas para propiciar las relaciones intergubernamentales entre distintos niveles o sectores del Estado y con los gobiernos de otros países.

Dichas formas de gobierno electrónico variaran en su configuración según áreas de servicio desempeñadas por las organizaciones públicas y acorde a las prestaciones que lleguen a cumplir las administraciones. En ese marco el qué, el para qué, el cómo, el quiénes y el dónde de las TIC, dependerá de las situaciones y funciones particulares que dentro de la administración se lleguen a presentar. Según el área administrativa se abre una gama amplia de servicios y de apoyos que pueden prestar las TIC. Un cuadro diseñado por estudiosos del tema, Joseph Rhoda y David Kitlan (2008), permite evidenciar cómo se llenan de contenidos específicos las soluciones informáticas. 
Table 1. Interaction of e-government and public administration.

\begin{tabular}{|c|c|c|c|c|c|c|}
\hline $\begin{array}{r}\text { Public Administration } \\
\text { Functions } \\
\text { Eonstituents }\end{array}$ & $\begin{array}{c}\text { Human } \\
\text { Services }\end{array}$ & $\begin{array}{c}\text { Community } \\
\text { Services }\end{array}$ & Transportation & Justice & $\begin{array}{c}\text { Land } \\
\text { Resources }\end{array}$ & $\begin{array}{c}\text { Financial } \\
\text { Services }\end{array}$ \\
\hline Citizens & $\begin{array}{c}\text { Consumer } \\
\text { safety }\end{array}$ & Post Offices & $\begin{array}{c}\text { Driver } \\
\text { Licenses }\end{array}$ & $\begin{array}{c}\text { Law } \\
\text { enforcement }\end{array}$ & $\begin{array}{c}\text { National } \\
\text { Parks }\end{array}$ & $\begin{array}{c}\text { College } \\
\text { scholarships }\end{array}$ \\
\hline Businesses & $\begin{array}{c}\text { Safety } \\
\text { standards }\end{array}$ & $\begin{array}{c}\text { Worker } \\
\text { training }\end{array}$ & $\begin{array}{c}\text { Regulate } \\
\text { trucking }\end{array}$ & $\begin{array}{c}\text { Control } \\
\text { cyber-crime }\end{array}$ & $\begin{array}{c}\text { Water } \\
\text { conservation }\end{array}$ & $\begin{array}{c}\text { Loans and } \\
\text { grants }\end{array}$ \\
\hline Employees & $\begin{array}{c}\text { Evaluate } \\
\text { standards }\end{array}$ & $\begin{array}{c}\text { Support } \\
\text { community } \\
\text { groups }\end{array}$ & $\begin{array}{c}\text { Provide } \\
\text { transportation } \\
\text { Geport }\end{array}$ & $\begin{array}{c}\text { Exccute } \\
\text { transfer }\end{array}$ & $\begin{array}{c}\text { Payroll } \\
\text { processing }\end{array}$ \\
\hline Governments & $\begin{array}{c}\text { Military } \\
\text { bases }\end{array}$ & $\begin{array}{c}\text { Flood } \\
\text { recovery }\end{array}$ & $\begin{array}{c}\text { Regulate } \\
\text { trade }\end{array}$ & $\begin{array}{c}\text { Public } \\
\text { safety }\end{array}$ & $\begin{array}{c}\text { Land } \\
\text { transfers }\end{array}$ & $\begin{array}{c}\text { Budget } \\
\text { creation }\end{array}$ \\
\hline
\end{tabular}

Joseph Rhoda y David Kitlan. Key Issues in E -Government and Public Administration. En: Handbook of Research on Public Information Technology. Volume I. New York: Information Science Reference. 2008. p.4.

\section{Organizaciones públicas y TIC}

Si bien mediante el E-government o gobierno electrónico en el sector público han ganado terreno las TIC, ellas no se agotan en él. Su importancia cobra relevancia también si se tiene en cuenta el papel que ha cobrado la información respecto a las organizaciones públicas. Al respecto, las TIC les abrieron múltiples posibilidades para que llegaran a contar con capacidades que les permitieran hacer frente a la gran cantidad y complejidad de información que deben manejar. Igualmente, les aportaron simultaneidad y deslocalización en el uso de la información, al igual que, les generaron posibilidades para procesar, acceder y disponer información de manera rápida y selectiva (Maureen, 2005). En términos generales, las TIC les trajeron a las organizaciones públicas la posibilidad de lograr un manejo ágil, oportuno y económico en el archivo, procesamiento, acceso y disponibilidad de la información.

La ganancia de capacidades en el manejo de la información se constituye en un asunto estratégico y vital para las organizaciones públicas, lo anterior, dado los miles y millones de ciudadanos con los que tienen que interactuar sus agentes y los acervos inmensos de información acumulados tras años de prestación de servicios. Valorar el importante papel cumplido por las TIC en relación con la información puede convertirse en una cuestión abstracta, por lo cual, puede ayudar a su comprensión aludir a un caso concreto. Al respecto, puede pensarse en los sistemas de salud pública nacionales donde en un sólo día se llegan a disponer de cientos y hasta miles de expedientes de pacientes, y los cuales por cierto, son consultados en simultánea desde 
un número amplio de terminales diseminados por distintos puntos de la geografia. Esto se complejiza, si se tiene en cuenta que dicha información se amplía exponencialmente en los meses, años y hasta décadas de consultas y/o servicios prestados por las organizaciones y agentes que integran dicho sistema.

Sin perder de vista la importancia que hoy cobra la información para las organizaciones públicas, no puede perderse de vista otro aspecto asociado a las TIC. Al ser la administración pública un fenómeno inter y macroorganizacional, al igual que intergubernamental, dicha configuración no debe ser dejada de lado al momento del diseño y manejo de los sistemas electrónicos de información. Esto no es ignorado en el mundo de los sistemas informáticos, ya que del paradigma de recolección, archivo y procesamiento de información volcado en exclusiva hacia el mundo interno de las organizaciones, cada vez más, se está pasando a otro donde se la divisa en función de la red inter-organizacional en que ellas participan. Bajo éste paradigma emergente, uno de los imperativos de la información en la actualidad es que la misma deba estar disponible a una gama diversa de organizaciones en diferentes lugares y para usos distintos.

Compartir la información más allá de las fronteras de cada organización, se erige en uno de los objetivos básicos de la administración pública contemporánea. No es extraño que a la fecha, distintas instituciones públicas compartan recursos tecnológicos que les permiten recolectar, migrar y analizar información en común y entre múltiples sectores y niveles (Maureen, 2005). En ese marco, realizan alianzas o acuerdos para compartir bases de datos, software, o en un grado más profundo, equipos, servidores y redes. La idea que fundamenta dicho tipo de colaboración es que para asegurar el éxito del sector público en su conjunto cada organización debe entender los procedimientos y las culturas de esas otras organizaciones con las que interactúa. Lo precedente implica, que las aplicaciones informáticas sean compatibles y articuladas a todo lo largo de un sector, de una política pública, e incluso, de la totalidad del aparataje público. Asegurarse de ello, se traduce para las organizaciones en la necesidad de realizar acuerdos y entrar en coordinación acerca de protocolos comunes para el manejo, migración y transferencia de la información.

Acorde a lo señalado por expertos, para conseguir el éxito de los sistemas integrados de información en el mundo inter-organizacional se debe contemplar una serie de principios. Entre estos se cuentan: 1) Que los sistemas sean diseñados teniendo en cuenta los distintos sistemas y las 
responsabilidades con que cuenta la organización en su articulación con los contextos o ámbitos en que se desenvuelven. 2) Que las estandarizaciones de sus datos deben partir del hecho de atender los requerimientos de todas las unidades y de los agentes que conforman la organización pública, al igual que, los de la red inter-organizacional en la cual se halla inmersa. 3) Que el suministro de la información depende de si sus agentes perciben que podrán beneficiarse, hacer uso de ella y si consideran que no será usada en contra suya. 4) Que el diseño y los dispositivos tecnológicos e informáticos deben tener en cuenta los estándares establecidos y aceptados en el mundo tecnológico global sin quedarse adheridos a los patrones locales o propios del consultor de turno. 5) Que el sistema integrado de información debe tener en cuenta las capacidades diferenciales de las organizaciones o actores que entrarán a participar en él. 6) Que hay que observar que algunos tipos de información exigen contar con sistemas de seguridad ${ }^{15}$.

\section{El aprendizaje y la enseñanza de las nuevas tecnologías}

Aunque en las tres décadas pasadas se dio una proliferación de las TIC y del gobierno electrónico, estudios recientes sugieren que los beneficios, potencialidades y promesas con que vinieron acompañadas no están garantizadas. A pesar del gran crecimiento en el uso de los medios electrónicos en el sector público, no puede concluirse que con ellos se haya dado una transformación profunda de los Estados y de sus democracias. Un estudio hecho en Estados Unidos encontró que a pesar de haberse gastado en dicho país durante una década más de 200 billones de dólares en sistemas y administración de información, era poca la evidencia acerca de los retornos producidos por las mismas (Brown, 2005). Se señalaba en dicho estudio, además, que al momento de su realización aún había en el Estado pobres servicios, altos costos, baja productividad, riesgos innecesarios y oportunidades inexplotadas.

Otras voces han señalado también que aunque se enarboló que las TIC permitirían la construcción de organizaciones horizontales, hoy es claro, que su uso puede afianzar pautas de verticalidad y de control a su interior (Scavo, 2005). Señalan que como ellas pueden servir a propósitos democráticos, también, pueden soportar objetivos antidemocráticos acorde a las instituciones y normas que las regulen. Aunque son muchas las

15 Al respecto de éstos estándares ver los distintos artículos que integran el texto de: Handbook of Research on Public Information Technology. Volume I. New York: Information Science Reference. 2008 
ilusiones que ha despertado, no hay garantía alguna de que las TIC hayan incrementado el espíritu de la comunidad, y cabe la posibilidad, de que por el contrario puedan erosionarlo. El acceso a internet no necesariamente ha mejorado la capacidad de los ciudadanos para interactuar con sus gobiernos, ni tampoco, con otros ciudadanos. Dado todo lo anterior, una de las preguntas que ronda incesantemente es si una vasta inversión en tecnologías en el sector público, como ocurre ahora, está justificada en términos de los desarrollos que han traído.

Diferentes problemas u obstáculos pueden existir para que no se dieran mayores impactos, tales como, sectores de la población o regiones con dificil acceso a las tecnologías, débiles infraestructuras de conexión y transmisión de datos y/o baja educación y resistencia al cambio. Factores políticos propios del sector público también pueden estar en la base de dichos resultados y entre los cuales se cuentan capturas del Estado por parte de elites, políticos, burocracias y/o contratistas que lejos están de querer permitir que las tecnologías tengan mayores o mejores resultados en materia de eficacia y transparencia. En todo caso, hay que decir, no puede caerse en el fetichismo que considera que por cambiarse las mediaciones tecnológicas se transformarán por arte de magia las relaciones y prácticas sociales y políticas. No hay que olvidar que las tecnologías adquieren sus sentidos y sus usos, según los contextos sociales y políticos en los que se inserten y de las lógicas de apropiación con que sean asumidas. En ese sentido, para que las TIC sean útiles, las mismas deben estar soportadas por procesos y equipos robustos que en las organizaciones valoren, administren, gestionen, actualicen y protejan la información.

Un problema sobre el que se quiere llamar la atención aquí, y que pocas veces se le presta, es sobre qué tan preparados están los agentes públicos para proyectar y aprovechar las potencialidades de las TIC. Es así que los mejores hardwares y/o las mejores plataformas tecnológicas suelen quedar subutilizadas si quienes las operan no conocen y saben aprovechar sus prestaciones y potencialidades. En el caso de los Estados Unidos, especialistas consideran que la primera razón para que las tecnologías informáticas hubieran tenido efectos limitados, era la falta de conocimiento y las bajas capacidades en su operación (Brown, 2005). Más grave se volvía dicho déficit en tal país, cuando otros especialistas encontraban que a los empleados públicos se les exigía tareas que requerían altos niveles tecnológicos, pero en contraste, era baja la provisión de capacitación o formación que recibían (Vocino, 2011). 
Esto conduce a un tema central relacionado con los procesos de capacitación y formación en las TIC para los servidores y directivos públicos. Surge la pregunta entonces de ¿cuáles son las competencias hoy necesarias en la formación y capacitación de los servidores públicos?, pero más importante, ¿cuáles son las que se requerirán en los próximos años o décadas en un contexto de cambio tecnológico vertiginoso? Quizá no haya una respuesta única o acertada a tal interrogante ya que su respuesta dependerá de los contextos nacionales y sociales en los que se hagan los procesos de adopción de las TIC. Lo cierto es que, en una sociedad de la información y el conocimiento, tal como ha sido bautizada por algunos especialistas, saber pensar y hacer uso de las tecnologías se convierte en la diferencia entre estar incluido o excluido del mundo laboral y comunicativo, pero también, de encontrar las mejores y más oportunas respuestas a problemáticas de la sociedad y de sus instituciones.

Sólo para hacerse una idea de cómo ha sido y hacia a dónde apunta la formación en habilidades tecnológicas en quienes hacen parte de las administraciones públicas, es pertinente traer a colación otro estudio hecho en los Estados Unidos. En dicho país se cuenta como antecedente que desde los años 80’s ya se había planteado el debate acerca de la necesidad que tenían los graduados en carreras de administración pública o afines de adquirir competencias básicas en medios tecnológicos. Respondiendo a dicho debate, en 1986, la Asociación Nacional de Escuelas de Asuntos Públicos y Administración (NASPAA) promulgó directrices para que los currículos las adoptaran en lo relacionado con computadores y sistemas de información. Consideró este organismo, que debía haber un esfuerzo por parte de los programas en asuntos públicos y en administración pública para proveer formación respecto al uso de las nuevas tecnologías en el sector público.Ya en 1990, otros estudiosos, señalaron que dentro de las diez competencias que debían de enseñar en los programas de Administración Pública (los Máster y Maestrías), varías de ellas, tenían que ver con el manejo de computadores, la búsqueda de información, la estadística y el análisis de datos (Vocino, 2001) ${ }^{16}$.

Un nuevo estudio se desarrolló en EE.UU en años recientes para determinar cómo se impartían conocimientos y competencias en el campo de las

16 En consonancia con dicho diagnóstico, diferentes programas entrarían a ofrecer cursos relacionados con tecnologías de la información. Entre sus ofertas se contarían cursos en métodos de investigación, procesamiento de datos, estadística básica, matemática avanzada, programación de computación, investigación de operaciones y uso de microcomputadores. 
tecnologías en los programas de Máster en Administración Pública. Con base en él, se estableció que mientras que a finales de los 80’s e inicios de los 90’s la formación en TIC se centraba en el uso del computador, la búsqueda de información, las hojas de cálculo, el manejo de bases datos, la administración financiera y la administración de personal, ya en 2003, los campos en los cuales se centraba la formación habían cambiado y se habían ampliado de manera significativa. En adelante, las áreas en torno a los cuales los cursos gravitaban en ese momento era la búsqueda de información, comunicaciones electrónicas, paquetes estadísticos, gráficas, hojas de cálculo, administración y procesamiento de datos, análisis de costo-beneficio, administración financiera, presupuestos, modelización econométrica, modelización de investigación de operaciones, sistemas geográficos de información, proyecciones económicas y soportes para la toma de decisiones. Se trataba de una vasta gama de aprendizajes.

No puede generalizarse los hallazgos encontrados en EE.UU a otros países, pero si, dan cuenta que la formación en sistemas y tecnologías informáticas no solo está en déficit, sino que es algo que está cambiando con una rapidez acelerada. Además, invita a pensar que una de las tareas pendientes es no tanto adiestrar a los agentes públicos en herramientas informáticas, sino más bien, enseñarles a pensar y a manejar con destreza el mundo tecnológico según los niveles y sectores en que se desenvuelvan o puedan llegarse a desenvolver. La respuesta a grandes o pequeños desafíos y problemas del sector público, pueden estar, en conocer y saber utilizar los principios y las prestaciones que brindan las TIC.

\section{Comentarios finales}

En el último cuarto de siglo XX y lo corrido del XXI, las Tecnologías Informáticas y Comunicativas (TIC) han ganado terreno no sólo en la vida de las personas sino en el sector público. Lo han hecho, entre otras, porque han contribuido a generar capacidades de distinta naturaleza al interior de la administración pública y a las relaciones que ella tiene con la sociedad. Las TIC pueden aportar a abrir las puertas a canales más amplios y versátiles entre los encargados del sector público y los ciudadanos; los directivos y sus empleados; los responsables del gobierno y los proveedores; los niveles nacionales y locales; los distintos sectores administrativos. Otras son los aportes que las TIC pueden hacer a las administraciones públicas en relación con sus organizaciones, procesos y políticas públicas. Lo anterior, si se tiene en cuenta: 
- Las capacidades exponenciales que aportan al almacenamiento, recuperación y análisis de información.

- Las facilidades que brindan sus redes para propiciar el trabajo colaborativo al conectar en simultánea infinidad de puestos de trabajo, puntos de atención o entidades.

- Los soportes que proponen para conectar en tiempo real de manera virtual a territorios, poblaciones e instituciones distantes en lo que respecta a su localización geográfica.

- Las posibilidades que abren para acercar el Estado a los ciudadanos.

- Las capacidades que habilitan para la prestación online de servicios y bienes a los diferentes públicos ciudadanos y privados con que interactúa.

Es claro hoy que gracias a las TIC el acopio, archivo y recuperación de miles y millones de datos, ya no supone ingentes ejércitos de personal o inmensas locaciones para su acopio, o así mismo, meses para su ubicación y procesamiento. Por efecto de ellas, se requiere más bien, de reducidos equipos de personal, de plataformas de almacenamiento que ocupan poco espacio y de recuperaciones de información que requieren minutos, o acaso, segundos. Otras facilitaciones han abierto las TIC a la vida de los ciudadanos y de los funcionarios públicos. Trámites que antaño les implicaban demoras a los ciudadanos tales como el pago de servicios públicos, de impuestos, de obtención de licencias etc., gracias a ellas, hoy pueden hacerlas con rapidez y comodidad. Igualmente, para quien realizar trámites ante el Estado le suponía grandes desplazamientos, con las TIC, se le abrió las posibilidades para que pudiera realizarlas sin moverse de su casa o de su lugar del trabajo.

Para los funcionarios públicos, y más en general para la administración pública, las TIC abren la posibilidad de llevar control de los recursos del Estado. Les permite llevar un registro minucioso de los recursos financieros y activos con que cuenta el Estado y cómo los mismos se van ejecutando. Así mismo, les facilita identificar y focalizar con amplitud y rapidez los miles y millones de aportes que realizan los ciudadanos a las arcas del Estado, pero también, los amplios desembolsos dirigidos a sus beneficiaros. Igualmente, las TIC amplían las posibilidades a llevar un control de las acciones que cada una de las entidades y funcionarios realizan, para establecer, si las mismas están generando y agregando con ellas valor público. En fin, las TIC permiten hacer más integrados, rápidos y exhaustivos y los procesos de gestión. 
Las TIC no son la panacea. Su promoción puede estar cargada de promesas que no son posibles de cumplir, y además, inducir al fetichismo tecnológico que lleva a creer que ellas como objetos inertes son por sí mismas la solución a los problemas. Las tecnologías aunque sean las más sofisticadas, pueden no generar ningún cambio deseado, si ellas no están articuladas a transformaciones profundas en los comportamientos y relaciones de los agentes que interactúan con ellas. $\mathrm{Y}$ esto conecta con algo ilustrado en la exposición realizada en éste capítulo, donde se evidenciaba que es importante no sólo contar con soportes, plataformas y equipos tecnológicos de avanzada, sino también, en poder hacer uso de ellas y saber maximizar sus prestaciones o utilidades. Las sociedades y las administraciones deben educar a sus agentes para que puedan aprovecharlas y maximizar sus utilidades.

En ese sentido, se argumentó en relación con la importancia que tiene hoy por hoy, que las universidades avancen en la formación de sus graduandos en saberes y competencias tecnológicas e informáticas. Más desafiante, pero no menos importante, es el objetivo de que provean procesos de formación donde los profesionales al servicio del sector público aprendan a pensar tecnológicamente, que los lleve a asumir que, en toda solución de un problema administrativo, las TIC pueden constituirse en una variable clave. Sin embargo, esto supone conocerlas a fondo para identificar sus prestaciones, funciones, utilidades y alcances, pero también, en sus especificidades y compatibilidades con otras tecnologías.

Un elemento importante que se presenta hoy para los encargados y responsables del sector público, es saber qué tecnologías, equipos y plataformas se encuentran disponibles en el mercado y se hacen adaptables a sus necesidades, e igualmente, establecer cuál es la versatilidad de las mismas para adaptarse a otras necesidades existentes y venideras. También se trata de saber cuáles son los entornos tecnológicos del sector público, de forma tal que, las tecnologías que se vayan a adoptar en una organización o sector puedan generar prestaciones a otras instituciones, e igualmente, pueda conectarse y aprovechar los de otras. Todo lo anterior, porque no debe olvidarse que el sector público es un circuito integrado por muchas organizaciones dependientes entre sí que colaborativamente deben cumplir unos propósitos comunes. 



\section{LA INNOVACIÓN COMO CAMPO EMERGENTE EN LA ADMINISTRACIÓN PÚBLICA}

\section{La definición y la emergencia de un campo de estudio}

Hay un desacuerdo sobre qué es innovación y cuál es el núcleo del concepto. Algunos estudiosos señalan que con ella se busca investigar cómo hallar nuevas soluciones a problemas existentes (Ferreira, 2008). Una respuesta más completa, apunta a señalar que la innovación en el sector público refiere a los cambios en los cursos de acción de los gobiernos o de las instituciones, los cuales alteran el statu quo al plantear nuevas ideas o caminos para hacer las cosas (Rondinelli, 2007). El producto principal de ella es el éxito, plasmado este, en la transformación de determinadas situaciones, rutinas y culturas organizacionales. A lo largo de las tres últimas décadas, la innovación paulatinamente se ha convertido también en un campo de estudio. Bajo este, se ha buscado sistematizar y analizar académicamente experiencias exitosas con el objetivo de estudiar cómo se llegaron a generar soluciones en el sector público, e igualmente, cómo pueden hacerse transferibles a diferentes tipos de contextos (Sanford, 2008).

Los soportes institucionales que soportaron este campo de estudios, comúnmente fueron las alianzas entre gobiernos, universidades, instituciones internacionales y fundaciones privadas. Su principal estrategia ha sido la generación de premios y concursos a nivel nacional e internacional, con los cuales, se buscó recolectar y sistematizar información sobre distintas experiencias donde se daban solución a problemas de carácter gubernamental y/o administrativo (Ferreira, 2008). La Universidad de Harvard en EE.UU con su Escuela de Gobierno John F. Kennedy, jugó un papel clave en dar vida a este campo de estudio. Al asociarse con el gobierno norteamericano y conseguir el patrocinio de la Fundación Ford, crearía los Premios de Gobierno Americanos en 1985. Con ellos, generó incentivos para compartir información y recolectar datos valiosos de distintos lugares que trajeron como resultado stocks amplios de información sobre el sector público 
norteamericano. Al contar con dicha información, los investigadores de la Escuela de Gobierno pudieron llegar a conocer y evaluar lo acontecido con las instituciones públicas de diferentes partes del país y dar pasos hacia la teorización respecto a las razones de sus problemas y frente a los caminos de solución (Sanford, 2008). Autores hoy reconocidos en el campo de la Administración Pública acudirían a dichas fuentes recogidas para sustentar sus trabajos. Entre ellos, Michael Barzelay con su trabajo Atravesando la Burocracia o Eugene Bardach con su estudio Consiguiendo Agencias que Trabajen Juntas.

El campo de la innovación en el sector público desde el momento de su fundación en EE.UU ha ganado bastante terreno, al punto que, empezó a ganar acogida en otros países tales como China, Brasil, Chile, Sudáfrica, Italia, Filipinas, Perú, México, entre otros. Una experiencia que habla bien respecto de su acogida, es la acontecida en Brasil, cuando el Centro para la Administración Pública del Gobierno de dicho país, en unión con la Escuela de Administración Getulio Vargas y con el patrocinio de la Fundación Ford, lanzó los premios a la innovación en el año de 1996. Con ellos, tenía como propósito identificar y diseminar prácticas exitosas en el gobierno federal y los gobiernos estaduales, municipales e indígenas (Ferreira, 2008). Tras casi 10 años de existencia, el programa había registrado más de 8.000 experiencias exitosas provenientes de más de 890 municipalidades. A pesar de los cambios políticos y de gobierno del Brasil, casi el $94 \%$ de las innovaciones identificadas aún permanecían, mientras el $34 \%$ de ellas, habían llegado a ser replicadas.

La promoción y estudio de la innovación para la mejora del sector público no sólo se dio al interior de los países sino también a nivel internacional. En el 2000, la Organización de las Naciones Unidas (ONU) creó el concurso y los premios a la innovación en el sector público para reconocerla y fomentarla en sus países miembros. En 2011, dicho concurso había recopilado y premiado a más de 140 innovaciones exitosas (United Nations, 2011). A decir de sus organizadores, el objetivo buscado con el concurso y los premios sería no solamente el de mejorar el rendimiento de los gobiernos y las administraciones públicas de los respectivos países, sino también, generar un stock público de información y de conocimiento. Los impulsores tenían la esperanza que con las experiencias sistematizadas los hacedores de políticas públicas, los académicos y las personas interesadas en el tema, encontraran potenciales soluciones o ideas inspiradoras a los problemas y cambios que venían enfrentando los gobiernos. En todo caso, para la ONU, dicho campo se hacía necesario si se buscaban lograr los compromisos hechos en la Declaración del Milenio y otras conferencias regionales, donde se apostaba a 
eliminar la pobreza, la exclusión, la desigualdad, la amenaza ambiental, entre otros (United Nation, 2011).

Resulta importante revisar las áreas bajo las cuales se organizaron año tras año los concursos por parte de la ONU, ya que permiten divisar las temáticas que ganaron y siguen ganando relevancia en la promoción y estudio de la innovación. Un área, se refiere a las innovaciones generadas con relación a la prevención y el combate de la corrupción, la responsabilidad en el servicio público, la transparencia y la rendición de cuentas, el mejoramiento en los procesos y la prestación de servicios. Otra área, se refiere a las innovaciones en la educación, la salud, la justicia y la seguridad, entre otros. Una área más, está relacionada con la innovación en la promoción de la participación en la hechura de las políticas públicas, la aplicación de las tecnologías en el gobierno y el fomento del género al interior del sector público (United Nation, 2011).

\section{La innovación: sus desafíos y aportes}

Al estar en el corazón de este naciente campo de estudio los interrogantes acerca del cómo producir conocimiento y el cómo aplicarlo, la innovación se configura no sólo como un saber científico sino también tecnológico. Una de las preocupaciones de los estudiosos de la innovación es establecer cuál es el conocimiento que puede extraerse y construirse a partir de las experiencias estudiadas, e igualmente, encontrar la comprensión que permita definir cómo y por qué ellas pueden hacerse transferibles (Behn,2008). El centro de la discusión recae en descifrar si es posible auscultar con cierta precisión las causas y los efectos de dichas experiencias, y con ello, inferir los principios, relaciones y soportes que las hicieron posibles. Pero allí no se agota su desafío cognitivo. También debe indagar si los nuevos contextos donde potencialmente serán trasladadas cuentan con las condiciones necesarias para que sean adoptados los logros y aprendizajes extraídos.

Se ha cuestionado sí la estrategia de sistematización y análisis de experiencias relacionadas con la innovación es válida para llenar los estándares del conocimiento científico. En tal sentido, se ha presentado la inquietud y la controversia de hasta dónde los casos coleccionados pueden dar paso a teorías generales acerca de la administración pública o el gobierno, o igualmente, si permiten dar lugar a conocimientos hipotéticos. No hay una respuesta definitiva. A diferencia de algunas ciencias duras experimentales donde se cuenta con laboratorios para llevar a cabo el control de variables 
y se pueden ensayar y repetir operaciones, en el caso de la innovación en el sector público, ello no es posible. Por tratarse de fenómenos de naturaleza social y política que acontecen in situ, no es posible llegar a auscultar con total precisión los mecanismos causales o explicativos que están en su base. Sólo se puede hacer un conocimiento aproximativo de dichas experiencias, pero con el problema que quiénes las diseñan y las desarrollan, no tienen la apuesta expresa de sistematizar y explicarlas científicamente.

La complejidad en la tarea del estudio de la innovación es puesta de presente por un especialista en el tema, que señala lo siguiente: quienes hacen la innovación no piensan en que otros puedan realizarla; quienes la adoptan pueden fallar en replicarla; y finalmente, quienes la crean pueden querer que no sea replicada (Behn, 2008). En el marco de dicha complejidad, ciertos conceptos vienen siendo acuñados para analizar e impulsar los procesos de innovación. A continuación se relacionarán algunos de ellos. Se habla de la difusión, para hacer referencia a un proceso espontáneo y no intencional de trasmisión y aplicación de conocimiento, cuya característica básica es, que agentes se enteren de lo realizado en algunas experiencias y opten por pensar que podrían reproducirlas. Por su parte, se alude a la transferencia, para indicar una apuesta más formal y sostenida, donde existe un conjunto de individuos enfocados en cómo hacer mejor las cosas, y que para lograrlo, llegan a comunicarse con otros y entre sí para compartir experiencias y aprendizajes. La propagación, por su parte, es mentada para sugerir un esfuerzo premeditado mayor, donde algunos individuos se comprometen activamente a promover experiencias de innovación y crear estrategias de educación y de asistencia para realizar la trasferencias de aprendizaje a otros. Finalmente, se alude a la réplica, como un término usado para referir al esfuerzo consciente de organizaciones para crear una estrategia deliberada de educación y asistencia que sirva para conocer y transferir innovaciones exitosas.

La innovación en el sector público está íntimamente ligada a las teorías que estudian el cambio organizacional. Así, desde perspectivas que la analizan y la proyectan, ella debe ser leída a la luz de ciertos paradigmas o modelos que pretenden explicarla. Sobre la base de uno de ellos, la innovación puede ser entendida como un proceso paulatino de progresión logrado a través de diversos estadios o fases planificadas y reguladas institucionalmente, y por lo tanto, ha de comprenderse a partir de diferentes etapas relacionadas con la formulación, implementación, evaluación y modificación de ella. Sobre la base de otro modelo, la innovación se genera gracias a que distintos actores y organizaciones se enfrentan y compiten entre sí por los recursos 
$\mathrm{u}$ oportunidades presentados en el ambiente externo que comparten; el resultado de dicha rivalidad, son cambios en los modos de funcionamiento y actuación de las partes en competencia. Sobre la base de otro modelo, la innovación es el resultado del aprendizaje y contagio entre organizaciones, lo cual lleva a hacerla ver como un proceso espontáneo que aunque monitoreado, se da en el marco de las interacciones e intercambios sostenidos entre distintas organizaciones (Poole, 2004).

\section{Innovación y reforma del Estado}

Si bien la innovación puede ser vista como un campo de estudio en formación cuya lógica está estructurada básicamente en los estudios de experiencias exitosas, expertos divisan también, que la misma debe analizarse en una escala más amplia. Por lo mismo, invitan a concebirla a la luz de las grandes reformas del Estado, y por esa vía, a ser conceptualizada como el conjunto de transformaciones en las concepciones y los modos de operación del sector público de los países. Tales transformaciones del Estado, son leídas entonces como soluciones globales a ciertos problemas provenientes de las sociedades, o igualmente, como medidas que buscan dar respuesta a agendas acordadas entre países o con organismos multilaterales. Bajo este enfoque, la innovación viene a ser la resultante de transformaciones institucionales de alcance nacional las cuales traen aparejadas cambios sustantivos en los gobiernos y en los aparatos administrativos.

Este movimiento de Reforma del Estado asociado a la innovación se expresa bien en una encuesta practicada en 1999 en distintos países. Ella encontró que en la dos décadas precedentes, el 50\% de 123 de ellos había tenido algún movimiento de reforma, y al menos un $25 \%$ había tenido dos o más reformas (Kamarck, 2003). Tal movimiento de reformas realizadas en muchos países dan para pensar que se trató de un movimiento de escala mundial; toma consistencia dicha hipótesis, si se observa el posicionamiento logrado por ciertos términos y conceptos comunes que circularon en los ámbitos académicos e institucionales a finales del siglo XX e inicios del XXI. Los mismos quedaron plasmados en distintos rótulos como "la Reforma Administrativa”, "la Nueva Gestión Pública”, "La Reinvención del Gobierno" o "la Gobernanza Centrada en el Ciudadano" (Sanford, 2008). $\mathrm{Al}$ ser compartidos en diferentes países, dichos rótulos dan cuenta de que las Reformas habían sido diseñadas con coordenadas políticas, intelectuales e ideológicas cuyo alcance iban más allá de lo circunscrito a un país. 
Varios fueron los significados y los sentidos que se atribuyeron a la innovación en el sector público a la luz de las reformas del Estado. A este respecto, dos marcos dominantes prevalecieron: o bien, ellas se orientaron a un gobierno y administración basados en los negocios y la privatización, o bien, se orientaron a posicionar la ciudadanía, los derechos y la inclusión social (Ferreira, 2008). Entre esos dos extremos, para algunos, la innovación sería el lenguaje cifrado y maniqueo para encubrir las imposiciones de las agencias multilaterales o de las obligaciones derivadas de los acuerdos entre naciones. Para otros, significaría la reforma de las viejas burocracias para adecuarlas o transformarlas a nuevos Estados democráticos e inclusivos. Para unos más, se asumiría como el camino para modernizar sus aparatos de gobierno y de administración conforme a las herramientas propias de la era de la información.

Uno de los factores centrales que estuvieron en la base de las reformas del Estado fueron las crisis económicas y fiscales de los países. Por esta vía, se asoció la innovación a las reformas conocidas como neoliberales y las cuales centrarían sus esfuerzos en la liberalización económica y en la privatización de las industrias del Estado (Kamarck, 2003).Tal orientación neoliberal primaría en los países en desarrollo donde la reforma se sustentó en las directrices trazadas por los organismos multilaterales, las cuales fueron asumidas por los Estados Latinoamericanos como contrapartida a los préstamos financieros recibidos. En dicho marco, la reforma se desenvolvió en dos generaciones: la primera de ellas, se orientaría a las privatizaciones, los recortes fiscales y los procesos de apertura económica, mientras la segunda, apuntaría a producir cambios en los campos de la justicia, la educación, los servicios públicos, la administración tributaria y la descentralización (García, 2003).

A pesar del peso preponderante que tuvieron las razones económicas en la reforma del Estado, otros países, se verían comprometidos con ella por motivos diferentes. Uno de ellos, estaría dado por el tránsito realizado de muchos países de regímenes autoritarios a regímenes democráticos. Un caso paradigmático de esta modalidad fue el de Sudáfrica que con la llegada de Nelson Mandela al poder y con el horizonte de finalizar el apartheid racial en dicho país, se dio la reforma de sus aparatos administrativos y de gobierno para que fueran más inclusivos de los distintos sectores raciales de la población. Se trataba con la reforma de eliminar las discriminaciones históricas insertas en sus tradiciones, rutinas y culturas institucionales (Kamarck, 2003). A menor escala, y sin tanta visibilidad como la de Sudáfrica, las reformas del Estado por motivaciones democráticas también se llevaron a cabo en otros 
países donde desde tiempo atrás se venían tramitando conflictividades y tensiones identitarias. En ese caso, ellas se orientaron a impulsar el abrir espacios a otras poblaciones, etnias, razas o géneros en las políticas públicas y en sus organizaciones públicas (Colleman, 2001).

Los procesos de democratización sumados a las crisis económicas estarían en la base de las reformas del Estado, sin embargo, no fueron los únicos factores que condujeron a ellas. También, se suman las apuestas que intentaron atacar la inconformidad y desconfianza de los ciudadanos con el servicio público. Es el caso de los EE.UU, donde según señalan algunos especialistas los ciudadanos sentían que sus administraciones eran despilfarradoras, abusivas, grandes y burocráticas (Kamarck, 2003). En tal sentido, en dicho país se dieron movimientos tendientes a buscar eficacia en las políticas y presupuestos y a mejorar la prestación de servicios por parte del sector público. En esa búsqueda, tuvieron origen o acogida movimientos intelectuales que apostaron a poner en cintura las burocracias públicas, al turno que, a increparlas a generar resultados y a prestar sus servicios con mayor eficacia, eficiencia y calidad. Dichas apuestas, estuvieron acompañadas en no pocos casos, de iniciativas que buscaban apalancar y justificar la privatización del sector público.

La reforma del Estado aparte de atender a los móviles ya señalados, también respondió a procesos relacionados con la conformación de comunidades de países o de bloques regionales. Una vez se erigieron estas nuevas unidades supranacionales, las mismas empezaron a diseñar campos regulatorios comunes que comprometieron a sus países miembros en el cambio de sus aparatos legales e institucionales. Fue el caso de la Comunidad Europea donde se observó movimientos de reforma afines entre los Estados que la conformaron (European Comission, 2013). Entre las transformaciones que llegaron adoptar, se encuentran las que apuntaron a controlar el déficit fiscal, a promover gestiones de personal, a lograr presupuestos por resultados o a mejorar el servicio al ciudadano (Cassese, 2007).

Resulta cuestionable que las distintas reformas del Estado atrás relacionadas puedan calificarse como casos de innovación. Sin embargo, encontraban un terreno común con ella al plantear nuevas maneras de pensar y de proceder frente a las instituciones públicas. La innovación como lenguaje para promover o justificar las reformas del Estado, en la vida real no necesariamente se tradujo en una administración pública y gobiernos más democráticos, equitativos y comprometidos con la defensa de lo público. 
Más bien, podía ser una cortina de humo hecha de terminologías refinadas para favorecer a unos pocos mientras afectaban negativamente a muchos otros. Sin embargo, no todo el espectro de reformas tuvieron este signo, como lo demuestra aquellas que se produjeron para abrir las instituciones a las poblaciones discriminadas o generar mejoras en los servicios.

\section{Los campos de innovación desde las reformas del Estado}

Con las reformas del Estado ciertos ejes o tópicos se fueron configurando en relación con cómo pensar e incentivar la innovación en los países. El primero de ellos, fue el del posicionamiento del concepto de productividad con el cual se buscaba bajar los costos e incrementar los rendimientos del sector público. Para sus defensores, la discusión de la reforma no debía centrarse en si se reducía o no el tamaño y las funciones del Estado, sino más bien, en definir qué tan productivas eran las instituciones y sus diferentes funciones y componentes (Kamarck, 2003). Así, el problema no era si la reforma resolvía si debía haber más o menos funcionarios en el sector público, sino más bien, si ellos contribuían a la productividad de la población en general. Una herramienta práctica enmarcada en dicha formulación, y que en su momento fue presentada como una innovación, sería la del presupuesto por resultados. Este partía del supuesto básico de que podía incrementarse el ahorro y rendimiento de los recursos públicos si se formulaban y evaluaban los gastos, ingresos e inversiones a la luz de objetivos, resultados o productos claramente formulados. A la luz de dicha herramienta, en países como Francia, Estados Unidos, Canadá y Singapur, por no mencionar otros, se cambió la manera en cómo se diseñaba la planeación y ejecución de sus presupuestos.

Otra de los ejes sobre los cuales se dio la innovación fue el de la calidad de los servicios prestados por el gobierno y por sus administraciones públicas. Por calidad, se llegó a entender la restauración de la confianza de los ciudadanos en el Estado a partir de las mejoras articuladas al usuario, el producto y la organización ${ }^{17}$. En este marco, una estrategia común en distintos países para avanzar en la calidad de sus instituciones públicas fue la de instaurar las "Cartas Ciudadanas". Con éstas, se pretendía establecer estándares de calidad y normas de acceso en relación con los bienes y servicios prestados por el sector público. Para garantizar su efectividad, en un buen número de casos, se asociaron a la instauración de instancias reguladoras que actuarían como

17 En el primer caso, se definía la calidad según la satisfacción de quienes receptaran los servicios o bienes; en el segundo caso, se asumían según los atributos incorporados a los bienes y servicios ofertados; en el tercer caso, según la eficiencia y eficacia de los procesos administrativos. 
entes vigilantes para garantizar los intereses de los ciudadanos (Cunill, 2004). Dichas Cartas, se promulgaron en Inglaterra y luego se extenderían a otros países como los Estados Unidos, Bélgica, Francia, Portugal, Argentina, Brasil y Chile, entre otros.

Una estrategia más de innovación en el campo de la calidad en el servicio del sector público se expresaría en la instauración de sitios especializados de atención bajo la forma de ventanillas, quioscos o sistemas electrónicos. Se buscó con ellos que, los ciudadanos pudieran economizar tiempo y dinero en la realización de trámites, consultas o desembolsos. Con los sistemas electrónicos, impuestos, multas y pagos de servicios públicos, que hasta antaño suponían largas esperas, colas y trámites, encontraron fórmulas de solución oportunas y confiables. Una estrategia más para mejorar la calidad de los servicios prestados por el Estado, encontró un lugar en la apertura de espacios a la participación de los ciudadanos en la administración pública. El supuesto que soportó esta estrategia, era que el mayor peso de ellos en el sector público podría llegar a implicar mayor calidad y satisfacción en los servicios por parte de la ciudadanía (Kamarck, 2003).

Otra de las aristas en que se organizó la innovación, fue la alusiva a las mejoras que se podrían lograr en las administraciones públicas y en sus servicios mediante el uso de las TIC y gobierno digital. Una serie de potencialidades se imputaban a ellas, entre las que se cuentan el abrir el gobierno a los ciudadanos; brindar mejores servicios y a menores costos; mejorar los procesos organizacionales y la toma de decisiones; fomentar la transparencia del gobierno y cerrar las puertas a la corrupción. Otro campo interesante, fue el de los aportes de las TIC para lograr que la población hiciera más control social y estuviera más enterada de la acciones de las instituciones del gobierno y de sus autoridades.

\section{Comentarios finales}

Una característica de la Administración Pública como disciplina es que se le exige no sólo que explique situaciones o fenómenos dados, sino también que, acorde a propósitos de tipo político, técnico y/o social proponga intervenciones para transformarlos. Es en el marco de conseguir ese objetivo, donde en las últimas décadas emerge un campo de estudio relacionados con la innovación en el sector público. Cómo se vio en este capítulo, con la innovación se busca generar nuevos cursos de acción y soluciones a situaciones problemáticas que enfrentaban los responsables 
y encargados del sector público. Cuatro estrategias centrales entraron a soportar la edificación de este campo de estudio. La primera, fue asumir como valiosa las experiencias y conocimientos acumulados por los propios agentes e instituciones involucradas en el problema, al tiempo que, de sus soluciones encontradas. La segunda, fue desarrollar un interés académico por recogerlas y explicarlas en relación con cómo habían sido logradas para teorizarlas y hacerlas replicables a otras situaciones o contextos. La tercera, fue la concertación entre instituciones gubernamentales, académicas y del sector privado para fortalecer instituciones públicas y prescribir modelos de acción pública. La cuarta, fue la realización de concursos para recolectar experiencias de múltiples contextos, pero también, para darlas a conocer a través de publicaciones y foros.

Importante advertir, la innovación aunque supone la puesta en juego de la imaginación para crear nuevas respuestas a problemas administrativos, va más allá. Supone la generación de unas condiciones institucionales para que sea llevada a cabo como un asunto serio y riguroso. Por emocionante que pueda sonar el término, no se trata con ella de una cuestión donde se pueda jugar al ensayo y al error ya que los fracasos en la administración pública siempre implican grandes costos en términos monetarios, humanos y sociales. Por lo anterior, adelantar la innovación de forma responsable, supone la creación de centros de investigación y de observatorios, al igual que de equipos académicos y sistemas de información que permitan recoger y rastrear a profundidad experiencias que se vuelvan teorías o modelos de acción con la fundamentación y validez necesaria como para ser replicados con certidumbre y confianza.

De advertir es también que, la innovación trae un mensaje implícito que la puede llevar a ser vista como una oportunidad para enriquecer el estudio de la Administración Pública como disciplina, pero también, como una amenaza que puede llevar a deteriorarla. Se constituye en una oportunidad al abrir los espacios académicos y de gestión para incentivar la búsqueda de soluciones a problemas administrativos o de gobierno de vieja data, al turno que, por generar otras formas de pensar y proyectar el cambio institucional. Sin embargo, a la par que abre dichas oportunidades, puede llevar a banalizar o nublar la comprensión del cambio organizacional e institucional en el sentido de llegar a asumir que para llevarlo a cabo es suficiente la buena voluntad, el entusiasmo y la imaginación de las personas. $\mathrm{Y}$ no en su lugar, considerar que se requieren cambios profundos, por ejemplo, en las estructuras, las líneas de autoridad, en las relaciones de poder, 
en la división del trabajo, en la focalización de beneficiarios y aportantes, en el flujo de recursos de las organizaciones. Cuestiones éstas últimas que, sólo pueden ser identificadas en observaciones y análisis sistemáticos, rigurosos y prolongados en el tiempo.

El entusiasmo por la innovación puede generar saltos al vacío donde la observación y la explicación con atributos científicos pueden salir sobrando. Así mismo, puede llevar a un voluntarismo temerario de creer que se pueden cambiar las cosas sólo porque así se desea, o igualmente, que el cambio a generar es de por sí positivo sin contemplar si podría empeorar las cosas al traer mayores costos y/o consecuencias indeseables. Esto lleva a invocar sobre la necesidad de la investigación científica en este campo que lleve a sus agentes, primero, a que se esfuercen por comprender los mecanismos explicativos que dan cuenta del funcionamiento de la innovación en el sector público, y segundo, a que proyecten soluciones que sean replicables en otros contextos.

Otro de los riesgos en que puede traer la innovación como potencial campo de estudio de la Administración Pública como disciplina es que ésta la empuje solamente a ocuparse del estudio y la solución de los pequeños problemas, y con ello, bloquee la preocupación, mirada y discusión de los cambios estructurales que deben efectuarse en el mundo institucional del sector público. Sin embargo, como también se mostró en este capítulo, algunos autores conscientes de dicho riesgo, la estudian y conceptualizan bajo el lente de entenderla como reforma global y administrativa del Estado. Las respuestas a estas problemáticas transversales al Estado dieron lugar a estrategias y herramientas administrativas novedosas, pero también, controversiales. Entre las mismas, estuvieron los presupuestos por resultados, las cartas de servicio al ciudadano, la prestación de bienes y servicios por medios virtuales, las rendiciones de cuentas y el gobierno electrónico.

Las áreas temáticas a nivel micro donde se persiguieron soluciones novedosas fueron las referidas a la prevención y combate de la corrupción; la responsabilidad en el servicio público; la transparencia y la rendición de cuentas; la mejora en los servicios de educación, salud, justicia y seguridad; la promoción de la participación en la hechura de las políticas públicas; la aplicación de las tecnologías en el gobierno; y la promoción de género al interior del sector público. 



\section{V \\ ADMINISTRACIÓN PÚBLICA DIVERSA Y MULTICULTURAL}

\section{Orígenes y avances de la administración pública diversa y multicultural}

La administración diversa y multicultural es la consecuencia de los esfuerzos iniciados desde mediados del siglo XX orientados a eliminar la discriminación y a lograr la igualdad en el acceso al trabajo en el sector público (Colleman, 2001). Una combinación de las luchas sociales y de la apertura de los Estados por proteger grupos discriminados, terminarían por forzar a que las administraciones públicas de distintos países se hicieran más sensibles, abiertas y representativas a grupos tradicionalmente excluidos por razones, entre otras, de raza, etnia, género, edad, (White, 2015). Movimientos por los derechos de los negros, de la mujer, de los no nacionales, presionaron por la instauración de medidas favorables a una composición diversa y multicultural de las sociedades y de sus diferentes tipos de instituciones. Reformas a los Estados tendientes a la democratización, modernización y descentralización, también llegaron a favorecer las acciones a favor de la inclusión de la diversidad social (Ospina, 2001).

Diferentes manifestaciones y medidas promulgadas por las organizaciones internacionales evidencian dicho movimiento a favor de la inclusión y la no discriminación. En 1957, uno de los principios contenidos en el tratado de Roma, ya contemplaba la exigencia de medidas tendientes a lograr el igual pago a las mujeres que a los hombres. Por su parte, en 1997, en el marco del tratado de Ámsterdam, se firmó el compromiso por parte de distintos Estados europeos de promover la equidad y la lucha contra la discriminación. En el año 2000, la Unión Europea expidió una resolución en la que se prohibía la discriminación en las áreas de la salud, la educación, los bienes y los servicios (Page, 2008). Por su parte, el 2007, sería designado el "Año Europeo de las Iguales Oportunidades para Todos", resultante este del compromiso de la Comisión Europea por confrontar la discriminación e informar a la gente acerca de sus derechos. 
Donde mejor se evidencia la tendencia hacía la inclusión de la diversidad y la multiculturalidad en el sector público es en países integrados por grupos poblacionales con diferentes nacionalidades, culturas y etnias. En los Estados Unidos, por ejemplo, a inicios del siglo XXI el Gobierno Federal de dicho país estaba conformado por un 38\% de personal proveniente de minorías (Blue, 2003). Igualmente, en dicho país, se evidenciaba un amplio incremento de mujeres que laboraban en el sector público, de las cuales, un grupo significativo de ellas tenían hijos y compromisos familiares. Se sumaban como cambios en el servicio civil norteamericano, además que, al menos un $10 \%$ de la fuerza laboral estadounidense sufría de algún tipo de discapacidad fisica o mental. Así mismo, en dicho país se reportaba un cambio en los patrones de edad del personal adscrito al Estado al envejecerse y sin estar acompañado de una tasa de renovación generacional significativa. Además, se reportaba ampliación de la población homosexual empleada en el sector público, cuya discriminación no sólo era fuente de sufrimiento para aquellos que la vivían, sino que también, se convertía en el origen de conflictos laborales (Blue, 2003).

Todas estas transformaciones en el personal del sector público en los EE.UU, dan indicios acerca de la necesidad que tienen las administraciones públicas de pensar políticas y programas de personal y de reconocimiento a favor de grupos poblacionales que las integran. En América Latina, aunque aún no hay estudios directamente relacionados con la composición laboral del sector público, si hay algunos trabajos que vienen dando cuenta de las transformaciones de los Estados con ocasión de las luchas políticas, culturales y económicas emprendidas por parte de poblaciones tradicionalmente marginadas (Gavía, 2009). En particular, los movimientos indígenas y populares lograron una irrupción en la esfera pública política que les permitió que se reconocieran no sólo sus derechos alrededor de la cultura, de la autonomía o de la equidad, sino también, que se hicieran representantes suyos al control del poder político del Estado (Bolivia y Ecuador).

Producto de sus luchas, estaría la instauración a nivel constitucional de Estados plurinacionales que traían consigo la apuesta a una institucionalidad que respetara, promoviera e incluyera formas políticas y administrativas donde tuviera cabida la población proveniente de las comunidades indígenas tradicionales. En el caso de Bolivia, la plurinacionalidad se expresaría en transformaciones de las agencias de planificación, del sistema de salud, del sistema de educación, de las fuerzas armadas y de la policía. Estas instituciones, se ocuparon de agendas directamente relacionados con dichas poblaciones 
ancestrales, pero también, reclutaron a directivos y a personal provenientes de ellas (Santos, 2010). Otros países con menor proporción de población de procedencia indígena (Brasil, Paraguay, Chile, Colombia) sin llegar tan lejos como los estados plurinacionales, entraron a reconocer autonomías políticas a las comunidades indígenas que llevaron a instaurar otras formas de administración y gobierno territorial diferentes a las convencionales. Esto a su vez supuso, la incorporación de agentes provenientes de dichos sectores a los sectores públicos sub nacionales.

\section{¿Qué es y cómo se define la administración pública diversa y multicultural?}

Defensores de la administración pública diversa y multicultural señalan que ella implica un compromiso con el igual acceso al poder por parte de poblaciones tradicionalmente excluidas, y también, de medidas para que influyan en los distintos procesos de formulación e implementación de políticas públicas (Colleman, 2001).En ese marco se asume, que dicho tipo de administración busca remover las barreras históricas que han impedido el acceso y la promoción de ciertos grupos poblacionales a las organizaciones públicas y a las políticas públicas de los Estados. Se plantea además que, ella busca promover una idea de justicia democrática dentro de las organizaciones públicas al evitar la discriminación y pretender reducir la inequidad social (Ospina, 2001). Tendría la administración pública diversa y multicultural, como uno de sus propósitos específicos, incrementar la representación social y la creación de oportunidades económicas al interior de las instituciones públicas a favor de grupos marginados.

Tres paradigmas han primado en el entendimiento de la diversidad y multiculturalidad en el sector público: la discriminación, la legitimidad, y la efectividad (Popescu, 2012). El primero de ellos, desde un punto de vista político plantea la igual oportunidad de acceder al empleo en las organizaciones públicas por parte de minorías que históricamente han sido discriminadas, y en ese sentido, busca generar oportunidades equitativas a los diversos grupos que componen la población. El segundo paradigma, apunta a señalar que las agencias públicas serán más aceptadas y prestaran mejores servicios si llegan a valorar la diversidad; en ese sentido, parte del supuesto que al estar compuestas las entidades públicas por integrantes provenientes de diversas culturas, sus equipos de trabajo estarán en capacidad de tener un mejor conocimiento, una mayor sensibilidad y una mejor comprensión de 
las necesidades del conjunto de la población. El tercer paradigma, apunta que la diversidad laboral mejora los procesos internos y los ambientes organizacionales al incorporar múltiples perspectivas, asume como supuesto de partida, que el trabajo conformado por diversas de formas de ver el mundo ayuda a procesar, percibir, interpretar de manera efectiva la información y la toma de decisiones.

El peso que llegan a tener las identidades de las personas y de los colectivos en la estructuración y funcionamiento de los aparatos administrativos resulta fundamental. Marcas de identidad referidas al género, la raza la religión, la orientación sexual, la etnicidad, la edad, la habilidad física, la familia, la proveniencia geográfica, la educación y el estatus social, entre otras, por no saberlas tramitar desatan dinámicas conflictivas al interior de las organizaciones públicas (Ospina, 2001). Tales marcas, cobran gran valor en lo atinente al reclutamiento y remuneración en el empleo público, como también, en el trato cotidiano recibido por las personas. Con ellas, emergen gramáticas de poder que de forma sutil o abierta alientan a incluir y/o a excluir, a recompensar y/o a castigar, a jerarquizar y/o a subordinar, a reconocer y/o desconocer. Un ejemplo se da en el campo del género, donde se llegó a acuñar dos expresiones que circunscriben claramente las dinámicas de desigualdad y discriminación a que dan lugar las relaciones de poder organizadas alrededor de las marcas identitarias de género: "la Pared de Cristal" y "Techo de Cristal". La primera, refiere a las barreras invisibles que se erigen al acceso de las mujeres a los empleos públicos, mientras la segunda, alude a las barreras invisibles erigidas para impedir la equidad en la remuneración de ellas y su ascenso en las jerarquías y más altos cargos del mundo laboral.

Es evidente que las identidades de las personas y grupos son motivo de conflicto en las relaciones laborales y organizacionales cuando no son reconocidas a través de estrategias administrativas adecuadas. Un buen ejemplo de ello se presenta cuando a los cargos de mayor jerarquía en el seno de las organizaciones arriban personas con identidades pertenecientes a grupos no dominantes o minoritarios. Es el caso de los jóvenes, que al tener que dirigir a personas maduras o de mayor edad es probable que se vean enfrentados a su oposición; o el de las mujeres, que al ocupar cargos directivos encuentran altas posibilidades de resistencia de parte de los hombres; o así mismo, el de personas provenientes de culturas o etnias minoritarias que al ocupar cargos de liderazgo se pueden llegar a ver desconocidas por otras pertenecientes a las culturas mayoritarias. 
Tales conflictividades fundadas en motivos identitarios han traído efectos indeseados para las administraciones públicas.Y lo hacen, por traer consigo, entre otros hechos, bajos rendimientos de las personas involucradas en las disputas; mala reputación de las entidades al conocerse de manera pública que a su interior se discrimina; pérdida de trabajadores y de recursos económicos por efecto de litigios y demandas. Dichos efectos negativos lleva a decir que las administraciones públicas deben incorporar como una de sus variables de gestión y de gobierno las realidades identitarias que habitan a su interior.

La intervención que sobre dicha materia se haga desde el Estado, no debe reducirse solo a la generación de intervenciones encaminadas a promover una cultura de respeto a la diversidad y de fomento de la tolerancia. En efecto dichas medidas deben contemplarse, pero ellas resultan limitadas cuando no están articuladas a políticas que vayan más allá, es decir, a intervenciones que apuesten a generar acciones afirmativas a favor de grupos históricamente marginados y discriminados.

Una propuesta usual promovida por los defensores de la diversidad y la multiculturalidad, ya hecha realidad en algunos países, es que los cargos públicos de los Estados deben reflejar la composición y el peso de los grupos que integran la nación. Se expresa lo anterior, con las leyes de cuotas o de cupos mínimos que obligan a los sectores públicos a asignar una proporción mínima de cargos a personas provenientes de determinados grupos de la población excluidos. Igualmente, hace referencia a campañas, compromisos y políticas de los gobiernos contra la discriminación de ciertos grupos o sectores y a la consagración de derechos colectivos especiales, que en casos, son requeridos para defender y mantener vivas sus culturas y tradiciones.

El paradigma de inclusión de la diversidad y de la multiculturalidad aplicado a los cargos públicos, aunque es llamativo, a muchos les resulta problemático.Y lo hace, porque de llevarse a cabo las políticas de cuotas o cupos se quedaría sin piso uno de los principios fundantes de la administración moderna como lo es el mérito. Según dicho principio, sólo quienes demuestren su saber y su experticia a través de pruebas de conocimiento, han de ser reclutados para el empleo público. Se asume, desde la administración moderna que dicho principio es el mejor por eliminar el favoritismo personal o político y permitir la igualdad de los aspirantes al realizar una selección basada en la excelencia. Sin embargo, revisado más de cerca, puede cuestionarse que la selección acorde a dicho principio realmente cumpla con tales atributos, en relación a que sea objetivo, igualitario y con un soporte basado en la excelencia. 
Se menciona lo anterior, porque muchos sectores de la población al momento de participar en las pruebas de mérito en el sector público se encuentran en situaciones de desigualdad y desventaja, que los deja, o con menores opciones de ser aceptados a los concursos, o con más bajas probabilidades de ganar las pruebas. Por efecto de la discriminación histórica de la que han sido objeto, en muchos casos, los integrantes de dichos sectores arriban a las pruebas con menores grados de educación, con más pobres calidades en su formación y/o con más bajas trayectorias laborales. Además, cuentan con otro atenuante, referido a que las pruebas y jurados que sirven para evaluarlos y seleccionarlos, por norma, reflejan los supuestos y las realidades de las culturas dominantes - y no, de las minoritarias de donde suelen provenir-. Sin embargo, la alternativa tampoco parece ser el implementar a rajatabla el modelo de cuotas o cupos, ya que al eliminar el principio del mérito como criterio de selección del personal del Estado, puede abrir las puertas para que sea capturado por lógicas patrimonialistas y/o clientelistas que apelan al personalismo o al favoritismo que terminan por socavar el propósito público ¿Qué hacer?

Un camino intermedio puede proponerse en donde la política de cuotas o cupos necesariamente no deje sin validez el principio del mérito. Se hace referencia a un concurso de méritos donde de un stock total de cargos a proveer, o bien, se separe un porcentaje para sectores de la población históricamente excluidos, o bien, se distribuyan por categorías según el peso porcentual que tienen los mismos en la población total de un país. Asegurado ese cupo o esas categorías, ahora sí, las personas discriminadas o provenientes de diferentes grupos de la población pueden incorporarse a prueba de méritos y competir entre sí. Se trata de un modelo mixto, que busca asegurar un piso común de igualdad o de nivelación para los desiguales, pero también, que a través de no dejar de lado el criterio del mérito pretende generar similares oportunidades a los concursantes. Este modelo, se considera, tendría aún más pertinencia cuando se trata de instituciones o sectores que prestan servicios y apoyos a poblaciones históricamente discriminadas tales como indígenas, negros, mujeres, migrantes, discapacitados y homosexuales.

\section{El conflicto por el reconocimiento y la igualdad}

Hasta aquí se ha hablado de las administraciones públicas diversas y multiculturales, sin embargo, se guarda el temor de que aún no se haya entendido todo lo que está en juego con ellas. Por lo cual se quiere a continuación ilustrar qué implicaciones y significados tienen las identidades 
en la vida de las personas y de las sociedades, como también, el importante papel que frente a ellas tienen las instituciones.A continuación los argumentos.

Acorde a Charles Taylor, la identidad de una persona es la visión que ella hace de sí y que la define ante sí misma y ante otros. El problema en que radica la discriminación, es que una parte de ella viene estructurada por el reconocimiento que la persona llegue a tener o no por parte de otras. En tal sentido, su desconocimiento puede ser una forma de daño y de opresión que sumerge a la persona en un modo de vida falso, distorsionado y empobrecido (Taylor, 1994). Una muestra de lo anterior, es la reivindicación de las feministas que denuncian que en el marco de una cultura patriarcal las mujeres han interiorizado una inferioridad que les ha impedido disfrutar una autoestima propia. Algo similar pasa con los integrantes de poblaciones negras, los cuáles en muchos casos, denuncian que han llegado a tener una imagen reducida de sí mismos por efecto de una sociedad blanca que durante generaciones les sometió, y que por relaciones de poder, no pudieron evitar hacer propia la mirada que ellos proyectaban sobre sí. Por su parte, los indígenas en América por efecto de siglos de dominación de conquista y de colonia de los europeos españoles, portugueses e ingleses, terminaron por interiorizar una imagen que al hacerla propia los condujo a la subordinación y a la exclusión.

Cualquiera sea el caso, dichas formas históricas de discriminación evidencian que han existido y existen toda una serie de relaciones de poder históricamente construidas frente a ciertos grupos o sectores de la población. Al respecto de cómo se construyeron históricamente dichas relaciones, se pueden traer a colación las reflexiones hechas sobre el colonialismo por parte de Aníbal Quijano y Walter Mignolo. Dichos autores señalan que históricamente el sistema capitalista mundial legitimó su dominación y explotación sobre la base de elementos raciales. Así, refieren como con el proceso imperial de conquista y de colonia practicado por los países europeos, no sólo se dio lugar a una división internacional del trabajo basado en el despojo de metales preciosos de los territorios coloniales, sino también, de una división racial que hizo ver como válido y natural que por diferencias fenotípicas de raza y color era legítimo que unos sectores oprimieran y explotaran a otros.

Evidencian entonces Quijano y Mignolo como con la conquista de América, pero también de África y Asia por parte los países imperiales de Europa, el mundo quedo dividido entre una jerarquía de poder ocupada por los blancos europeos y un lugar de subordinación ocupado por negros, indios, amarillos y oliváceos (Quijano, 2000). Gracias a sus recursos de poder 
material e ideológico, los primeros sometieron durante siglos a la esclavitud $\mathrm{y}$ al trabajo forzado a las personas pertenecientes a estas poblaciones, como también, impusieron una rebaja al valor social que cobraban dentro del pleno de la sociedad.

Las asimetrías de poder históricamente construidas llevaron a las poblaciones sometidas o subordinadas, y a colectivos de las sociedades dominantes solidarizadas con ellas, a una serie de luchas sociales. Negros, mujeres, indígenas, trabajadores, campesinos, homosexuales, entre otros, se dieron a la tarea de ganar reconocimiento, equidad y derechos. En sus luchas, dichas poblaciones debieron de soportar desde descalificaciones sutiles hasta brutales represiones por parte de los sectores que con sus privilegios le dominaban y explotaban. En respuesta a dichas luchas, las élites que controlaban a los Estados tuvieron que abrir paulatinamente su compás político a reconocer las reivindicaciones de dichos grupos o sectores excluidos. En otros casos, los procesos de independencia nacional de colonias sometidas a los países imperiales abrieron las compuertas al reconocimiento masivo de derechos de diferente tipo a dichas poblaciones.

Estos movimientos a favor de la inclusión y del reconocimiento, llevó a que paulatinamente en el tiempo las diferentes regiones del mundo fuera perdiendo peso la tesis que por diferencias fenotípicas de raza, color o identidad, entre otras, era legítimo que hubiese la explotación, la dominación y la discriminación de unos sectores por parte de otros. Como efecto político, los Estados Nación tuvieron que incorporar en sus agendas políticas la cuestión del reconocimiento a poblaciones históricamente excluidas y segregadas. Sin embargo, aparece la cuestión de si las democracias liberales con su andamiaje institucional pueden dar cabida a la asimetría de poder y a la diferencia identitaria, cultural y social portada por dichos grupos. Al respecto, autores afirman que ellas son sospechosas de no poder lograrlo porque sus instituciones asumen de manera prevalente que no deben intervenir para proteger determinadas culturas o identidades por considerar que no tienen por qué desarrollar acciones afirmativas a favor de ciertos grupos históricamente discriminados. Igualmente, por asumir como única opción de protección a las poblaciones los derechos individuales y no los colectivos (Kimlicka,1995).

Como contrapropuesta a dichas posturas de las democracias liberales, se plantea por parte de teóricos y activistas, que sus instituciones deben de reconocer, antes que ignorar, las particularidades de las poblaciones y de los distintos grupos que las conforman. Acorde a Will Kimlicka (1995), en las 
democracias liberales el Estado se pretende neutral entre varios grupos con diferentes identidades, pero lo que queda establecido en realidad, es que privilegia la visión e intereses de una mayoría nacional en detrimento de otras minorías. El autor en cuestión, enfatiza entonces que hay un rechazo de los liberales de izquierda y de derecha por conceder derechos colectivos y diferenciales para los miembros pertenecientes a culturas minoritarias con tradiciones distintas. Tales derechos colectivos pueden tomar diversas formas, entre los que se cuentan derechos de representación especial a determinados grupos al interior de las instituciones políticas de la sociedad; derechos de autogobierno, donde se delegan poderes a unidades políticas y territoriales más pequeñas que los Estados nación; derechos poliétnicos, los cuales mediante ayudas financieras, fomentos o protecciones buscan proteger a ciertos grupos culturales o religiosos (Kimlicka, 1995).

Como respuesta a las luchas por el reconocimiento y la diferencia, los Estados paulatinamente han optado por garantizar la igualdad de diversos grupos y formas de identidad, al punto que, a la fecha es dificil encontrar democracias que no den algún sitio especial a reconocer las identidades, las culturas y las minorías desventajadas (Gutman, 1994). Es en dicho marco donde emerge la apuesta política por dar lugar a administraciones públicas diversas y multiculturales. Con ellas, se busca avanzar en desmontar al interior de las instituciones públicas las configuraciones de poder históricamente construidas, que aunque silenciadas e invisibilizadas, no por ello dejan de hacer sentir sus efectos negativos sobre los grupos y personas no pertenecientes a las razas, culturas, identidades o ideologías dominantes. Se trata con ellas de impulsar que dichos grupos puedan influir sobre los centros de poder que en el transcurrir del tiempo de las sociedades habían construido opresión y sufrimiento sobre sus vidas. Incorporarlos al Estado, es para ellos, contar con nuevos recursos de poder para remontar siglos y siglos de desigualdad, desconocimiento, dominación y explotación.

\section{Comentarios finales}

En este capítulo, se pudo evidenciar que hoy resulta fundamental que los gobiernos y las administraciones públicas permitan y promuevan la inclusión de los diversos grupos e identidades que integran la sociedad. Se trata de generar instituciones que tienen el compromiso con el igual acceso al Estado de los distintos grupos poblacionales que integran una sociedad. Igualmente, se entiende que se hace necesario el reconocimiento e influencia de la población con diversidad en la formulación e implementación de las políticas 
públicas. Al Estado y las administraciones públicas les resulta fundamental remover las barreras formales e informales sustentadas en patrones, prácticas y reglas excluyentes ligadas a la raza, al género, el origen, la religión, la lengua etc. Bajo dicha búsqueda los gobiernos y administraciones deben evitar, por ejemplo, que a las mujeres por su condición sexual se les impida acceder a cargos públicos o ascender en ellos, o igualmente, se les genere menores reconocimientos salariales a los obtenidos por hombres.

En países, se constata un crecimiento del número de grupos poblacionales provenientes de distintas naciones, etnias y culturas, que han obligado a las administraciones a asumir dicha variables como significativas para su organización. Una muestra es que, en las últimas décadas en los Estados Unidos una proporción significativa del personal del sector público está integrado por personas con culturas diversas, con edades disímiles, con preferencias de género distintas, con capacidades físicas o mentales desemejantes etc. Todo lo anterior, les ha llevado a sus administraciones y gobiernos a tener que integrar dicha multiplicidad a sus diseños, procesos y organizaciones.

La diversidad y multiculturalidad que hace presencia en el mundo de la administración pública,pero más en general,en las sociedades contemporáneas, ha sido fuente de conflicto y de oportunidad. En este capítulo se mostró cómo en las organizaciones públicas se presentan conflictos por la presencia de prácticas y pautas discriminatorias que terminan por afectar no sólo su clima laboral, sino también, los servicios y bienes que prestan a los ciudadanos. La conclusión a lo que lleva todo lo anterior, es que los diseños organizacionales y de personal deben asumir como unas de sus variables importantes de su accionar la diversidad y la multiculturalidad. No sólo debe reconocerse que hace presencia en ellas diferentes marcas identitarias, sino sobre todo, que se debe agenciar como propósito explícito de sus actividades y procesos administrativos y de gestión.

Tendencias del pensamiento y del accionar administrativo han visto la diversidad y la multiculturalidad no tanto como un problema político y social, sino también, como fuente generadora de oportunidades y mejores desempeños en las organizaciones y en los servicios prestados a la sociedad. Así, divisan como el reclutamiento de trabajadores de diversas culturas o naciones pueden asegurar mejor atención, bienes y servicio a los usuarios o ciudadanos, por contar, con integrantes de diferentes culturas, naciones, géneros, edades o etnias que pueden tener una relación más próxima y sensible a las necesidades y gustos de distintos grupos de la población a los 
que quiere llegar o impactar. El contar con ellos, se divisa como un plus, ya que aporta puntos de vistas culturales e identitarios distintos de cómo y desde dónde ver las problemáticas y sus soluciones.

Es importante recalcar que la administración pública multicultural y diversa no va solamente hasta el punto de garantizar el acceso y la promoción igualitaria del personal o de los procesos administrativos que compone el sector público. También refiere a la generación de políticas públicas, medidas especiales y a derechos a favor de ciertos grupos y a sus integrantes. Entre estos, pueden contarse autonomías especiales para el gobierno de comunidades étnicas o culturales; educación con contenidos, estilos y narrativas donde se respete y fomente las tradiciones o costumbres de ciertos grupos; el uso, promoción y protección de otras lenguas y lenguajes que deben ser usados por instituciones. Supone esta faceta de la administración pública, el despliegue de acciones afirmativas que permitan a poblaciones tradicionalmente excluidas quedar incluidas al darse el reconocimiento y respeto a sus diferencias. 



\section{VI}

\section{POSTCONFLICTO, ESTATALIDAD Y ADMINISTRACIÓN PÚBLICA}

\section{Elementos generales acerca del postconflicto}

Pensar el postconflicto en cualquier sociedad es un inmenso desafio. Implica entre otras cosas, poner en juego el conocimiento histórico de la realidad para saber por qué y cómo ha sido afectada la sociedad por el conflicto armado. Igualmente, supone realizar un ejercicio de imaginación política y técnica para divisar salidas y escenarios futuros que permitan superarlo. Se suma, un ejercicio del buen juicio para determinar qué debe y qué puede tramitarse en lo que ha de negociarse y realizarse cuando se quiere salir del conflicto. En este marco de pensar el postconflicto, es que se hace pertinente traer a colación las reflexiones hechas por analistas de otras latitudes quienes coinciden en advertir, que si de lo que se trata es de culminar con éxito los procesos de postconflicto, debe prestarse atención a unos desafios y escenarios centrales. Es de anotar que la base experiencial de sus análisis es amplía, ya que en la última mitad de siglo XX un tercio de los países del globo terrestre habían pasado por conflictos internos, al punto que, sólo en el 2009 se calculaba que llegaron a existir 36 conflictos armados en 27 lugares del mundo (Naciones Unidas, 2011).

Antes de entrar de lleno en dichos desafios planteados por los analistas, parece importante definir qué se entiende por postconflicto. En términos lingüísticos, se trata de una palabra compuesta, la cual está integrada por el prefijo post y por el sustantivo conflicto (post + conflicto $=$ postconflicto). Dado que el prefijo pos, según lo indica la Real Academia de la Lengua, significa "detrás de" o "después de", el término en cuestión remite a un escenario que habla de lo que acontece luego o de lo que sucede antes del conflicto. Al organizarse el término en una línea del tiempo que remite a un antes, un durante y un después, puede afirmarse que el postconflicto aunque deba ser planteado como un estado diferente al del conflicto, tampoco puede desligarse y plantearse sin hacer referencia al mismo. Así, se asume aquí 
que el postconflicto no es un estado donde se da la finalización definitiva del mismo, sino más bien, es una transformación suya. Dado lo anterior, se concibe entonces como aquel proceso de mutación de la conflictividad social, la cual en lugar de ser procesada a través de lógicas, comprensiones y mecanismos armados, se llega a hacer más bien, mediante procedimientos, mentalidades e instituciones de tipo democrático.

Lo anterior, supone no la eliminación del conflicto sino su transformación creativa y constructiva. Igualmente, el postconflicto ha de ser entendido como un horizonte y escenario presente-futuro donde se busca generar un cambio en las relaciones de poder. Por ello, se trata de cambios institucionales, pero, sobre todo, cambio en las relaciones, concepciones y recursos de poder entre los actores a involucrados en el conflicto armado. Tal cambio implica que, debe posibilitarse a los actores permutar sus mecanismos, recursos y rutinas armadas por otras que les permitan tramitar de manera pacífica, efectiva y perdurable sus intereses, preferencias, sentires, conflictividades y antagonismos. Dado que el postconflicto es un proceso de cambio en la conflictividad y en las relaciones de poder, el proceso mismo de la definición de qué es y qué debe ser el postconflicto es materia de disputa. El postconflicto requiere la construcción de correlaciones de fuerza políticas, intelectuales y morales favorables para que se defina qué debe ser y qué transformaciones debe incluir.

Sí los conflictos armados son heterogéneos, así mismo debe pensarse y proyectarse sus postconflictos. Conforme a lo anterior, aunque sean necesarias propuestas y agendas de alcance nacional que articulen marcos generales, parece necesario, también estructurarlo y proyectarlo como una pluralidad hecha de escenarios e iniciativas regionales y locales. Pensar así el postconflicto, es imaginarlo y encararlo desde una lógica en la que sus sentidos y avances adquiere expresiones territoriales, e incluso sectoriales, diferenciales. Supone además, pensarlo como un proceso construido en doble dirección, donde las decisiones y actuaciones nacionales se articulan con las realidades locales y regionales, pero igualmente, donde las iniciativas nacidas en los territorios logran ascender e interlocutar con las de tipo nacional. La comprensión heterogénea, implica además que, aunque se le imagine idealmente como un escenario en el cual hay una ausencia total de confrontaciones armadas en toda la espacialidad nacional, en la práctica, pueden coexistir escenarios pacificados con otras que están aún en negociación y hasta en confrontación (Brinkerhoff, 2007). 
Un punto que no debe perderse de vista para no desperdiciar la oportunidad que abre el pensar y constituir escenarios de postconflicto es tener en cuenta las restricciones que suelen rodearlos. Un primer punto a considerar, es que la gran mayoría de conflictos armados acontecen en países pobres o de recursos restringidos lo cual limita los medios y las capacidades institucionales disponibles para adelantar las tareas propuestas; se vuelve más problemático esto, si se examina que en los procesos de transición las tareas y las actividades a emprenderse son muchas mientras los recursos suelen ser limitados. Es también frecuente, que los compromisos exigidos y adquiridos entre las partes en negociación apunten a los más altos estándares sin que las mismas tengan en cuenta los recursos y capacidades necesarias para alcanzarlos. Así mismo, es común que al desafio de sanear los estragos negativos dejados por la guerra se sumen demandas de tipo histórico que ni siquiera fueron posibles de tramitar en situaciones de normalidad (United Nations, 2011).

Todo lo anterior, lleva a señalar que, pensar el postconflicto es también ocuparse de los medios necesarios para alcanzar los objetivos deseados de conseguir a través suyo; igualmente, debe calcularse las temporalidades e intensidades necesarias para conseguirlos. En el postconflicto tan importante como tener claro lo que debe pasar en un futuro, es prever, los esfuerzos y desafios que deberán enfrentarse para llegar allí. No debe olvidarse que si la firma de paz entre actores armados es dificil de conseguir, el período que sigue a una cesación del fuego, es igualmente compleja al generar una elevada incertidumbre política (Naciones Unidas, 2011).

\section{La legitimidad como dimensión esencial en el postconflicto}

Acorde con lo sugerido por analistas internacionales para alcanzar y hacer sostenibles los procesos de postconflicto, se requiere consolidar procesos de legitimidad (United Nations, 2003). Tales procesos pasan por la creación de escenarios que permitan la reconciliación y la construcción de consensos entre las partes, las cuales deben llevar, a la firma de acuerdos y a comprometerse con las instituciones democráticas que deberán regirlos a ellos y a las sociedades. En tal marco, es importante que las partes, y en general la sociedad, divisen los acuerdos e instituciones de gobierno pactados como mediaciones políticas válidas para tramitar pacíficamente sus mutuos intereses, preferencias y antagonismos. Han de asumir las partes que una institucionalidad y cultura democrática donde prima el diálogo, la concertación, la competencia electoral, remplaza las prácticas violentas de eliminación, coacción e intimidación propias de la guerra. 
Lograr la legitimidad requerida por el postconflicto implica no solamente que haya buenas intenciones y convicciones por parte de los actores enfrentados, sino también, que se generen garantías institucionales efectivas para que quieran y pueden proceder conforme. Las constituciones políticas de los países han sido uno de los mecanismos institucionales privilegiados para lograr dichas garantías, ya que en ellas como pactos políticos y legales se busca formalizar una legitimidad entrelazada de las partes (Bjornlund, 2007). Al ser norma de normas, garantizan la permanencia de los compromisos de paz en el tiempo y hace costoso su cambio, cuestión esta última, que blinda los acuerdos de potenciales cambios que fuerzas políticas o gobiernos sobrevinientes quieran hacer.

Como garantías institucionales, al mecanismo constitucional le siguen otras medidas recomendadas por los expertos relacionadas con la apertura de curules o escaños en los cuerpos legislativos. Con dicha apertura, las partes en negociación pueden participar en el poder político del Estado, y a partir de allí, asegurar no solo la permanencia de los acuerdos pactados, sino también, sus agendas e intereses a largo plazo vía confección de leyes. A dicha participación política en las instituciones de representación popular, le complementa, la reforma al sistema electoral el cual debe orientarse a posibilitar que las partes compitan con las garantías e igualdades necesarias para que el fraude y las asimetrías políticas en las justas electorales no sean posibles. Dicha, reforma debe permitir por demás que los actores en tránsito a la democracia vean en las elecciones un mecanismo válido para competir y acceder al poder político del Estado; su contrario en el pasado, había sido el uso de las armas o la intimidación mediante ellas.

Así, un postconflicto sostenible en el tiempo requiere de elecciones transparentes y limpias las cuales impidan la manipulación a favor o en contra de alguna de las fuerzas en conflicto. También guarda importancia, corregir las reglas y mecanismos del sistema de partidos que no permiten la participación, representación e inclusión de las distintas fuerzas que estructuran la sociedad. Es de anotar que los partidos políticos juegan un papel vital en el postconflicto, ya que de sus procesos salen los gobernantes y programas de los escenarios que siguen al conflicto armado. Que se inclinen a ser inclusivos, efectivos, transparentes e internamente democráticos, es abrir la posibilidades a avanzar significativamente en proveer canales para generar participaciones y diálogos públicos que permitan dar pasos hacia una sociedad reconciliada y democrática (Belman, 2007). 
A los mecanismos constitucionales, electorales y partidistas pueden sumarse otros. Uno de ellos, de corte incluyente, está dado por las formas de participación ciudadana con las cuales pueda asegurarse la existencia de procesos inclusivos que impidan retornar a asimetrías de poder que en el pasado pudieron estar en la base de los conflictos violentos ${ }^{18}$. Otro más, estaría dado por la promoción de procesos deliberativos y comunicativos que generen y mantengan una hegemonía ideológica y discursiva que presione a las fuerzas en tensión para que sus conflictos y antagonismos sean regulados y mantenidos dentro de marcos democráticos. Dado que este último mecanismo resulta determinante, a continuación se procede a aclararlo.

Una hegemonía ideológica y discursiva es crear una articulación entre distintos sectores de la sociedad que en sus prácticas comunicativas terminan por construir, compartir e imponer un sentido de lo que es y debe ser la realidad social y política. Con ella, se buscará lograr el posicionamiento y movilización de sentidos, significados, comprensiones y sensibilidades a favor de la democracia y en detrimento de la guerra. En su estructuración, las distintas fuerzas sociales convergen en alimentar, disputar y orientar los sentidos de eso que en determinado momento histórico es sólo un significante vacío en disputa y que está en búsqueda de contenidos: el postconflicto. Llenar de contenidos el significante vacío del postconflicto, es entonces mantener en el tiempo y en el espacio unas luchas democráticas comunicativas que favorecen la inclusión de los actores armados ilegales e institucionales como también, de los distintos sectores que conforman la sociedad ${ }^{19}$.

\section{La seguridad como soporte del postconflicto}

En la literatura internacional también aparece la seguridad como uno de los temas centrales o primeros a resolver en escenarios de postconflicto. Es evidente que sin el cese del fuego cruzado, e igualmente, sin la certidumbre de quiénes, cómo y cuándo se puede hacer uso de la violencia física, difícilmente puede hablarse que una sociedad ha superado o está en vías de superar su conflicto armado. No sobra decir que la población en general requiere de condiciones de seguridad para llevar a cabo sus actividades cotidianas, por lo mismo, sus integrantes exigen protección y respeto a su vida, dignidad y bienes. Un ambiente seguro para la gente, se constituye entonces en una

18 Vía referendos, consultas 0 asambleas constituyentes, 0 también, vía planeación o presupuestos participativos.

19 Luchas que deben mantenerse vivas, ya que siempre las hegemonías son conquistas parciales, contingentes y perdibles, que si no se mantienen, pueden devolver y hacer legítimas en la opinión pública y la cultura política de una sociedad que sean aceptadas y promovidas las opciones a favor de la guerra. 
condición esencial para el desarrollo social, político y económico de las sociedades (Ball, 2007).

Uno de los desafios centrales en contextos de postconflicto respecto a la seguridad, está dado por cómo lograr la centralización y monopolización legitima de la violencia fisica por parte del Estado. Esto se requiere porque la coacción física en sus formas policiales, militares, judiciales, ejercida de forma legal y legítima, puede evitar la depredación de poblaciones por parte de nuevos grupos o bandas armadas. Prevenir, sancionar y castigar la criminalidad, o persuadir a infractores de derechos de los demás, hace evidente que la violencia debe existir en las sociedades, pero eso sí, ejercida de forma legal y legítima El problema en el postconflicto, no es entonces el no uso de la violencia, sino más bien, acordar y regular en manos de quiénes, cómo y cuándo puede llegar a hacerse un uso legítimo de ella (Musoni, 2003).

Uno de los propósitos centrales de lo buscado con los acuerdos de paz es lograr que los actores irregulares hagan entrega de sus armas a cambio de contar con garantías civiles y políticas. Para ello, la entrega de armas por parte de los actores irregulares envuelve los procesos de desarme, desmovilización y reintegración (DDR). Mediante cada una de ellas, se busca asegurar que los combatientes pasen de una vida en armas a una civilidad pacifica con ejercicio de derechos, pero también, de deberes. No realizar ni culminar exitosamente dichos procesos, significa ni más ni menos, el posible fracaso en la terminación del conflicto armado y a un potencial retorno al mismo. Sin políticas públicas orientadas a crear empleo, participación política, integridad psicológica y educación para los excombatientes, entre otras, la transición de una sociedad en armas a otra democrática puede hacerse imposible de lograr.

De no generarse las condiciones adecuadas para los excombatientes, puede dar lugar a que los recién desmovilizados se reciclen en nuevas bandas armadas o en organizaciones no políticas de tipo criminal. El reto de un postconflicto es no sólo lograr la dejación de las armas por parte de los actores armados, sino también, el cómo lograr que no encuentren incentivos para retornar a ellas, o aún más, para que a futuro, otros actores civiles no se vean tentados a tomarlas.

Aunque el campo de la seguridad pasa por las políticas de desarme de los combatientes ilegales, no es el único que debe atenderse.Transcurre también por la reestructuración y reorientación de las fuerzas armadas y de seguridad del Estado, cuyas visiones, rutinas y mecanismos fueron configuradas para 
actuar en contextos de guerra. En los conflictos armados no es extraño observar que las propias fuerzas armadas institucionales llegaron a ser partes activas en excesos o irregularidades contra la población. Alianzas con grupos paramilitares, actuaciones ilegales, subordinación a élites locales, politización de la seguridad, mala administración de recursos, defensa de gobiernos represivos, son algunas de las prácticas que pudieron llegar a asumir en contextos de guerra. Dados los intereses creados, dichas fuerzas institucionales en escenarios de postconflicto pueden estar interesadas y actuar a favor de la prolongación del conflicto armado, y con ello, volverse fuentes de turbulencia, inseguridad y de coacción (Ball, 2007).

En los procesos de postconflicto, es importante avanzar en depurar, profesionalizar y reeducar a los cuerpos armados institucionales, e igualmente, reestructurar sus visiones, misiones y rutinas. El profesionalismo de las fuerzas armadas no sólo incluye la intervención sobre sus capacidades técnicas, sino también, sobre aspectos normativos relacionados con su respeto y sujeción a la ley y al poder civil. Su reeducación, pasa no sólo por nuevas competencias y roles frente al ejercicio militar o policial, sino también, por construir compromisos institucionales y éticos con los marcos constitucionales y legales del Estado de Derecho, el Estado Democrático y los Derechos Humanos. Incluye esto, avanzar en su subordinación efectiva a autoridades electas y civiles, y también, en imbuirlas en procesos de rendición de cuentas y de apertura a la sociedad civil para que hagan escrutinios de ellas.

En el postconflicto, en temas de seguridad, también se hace de vital importancia la provisión de servicios judiciales de justicia para el conjunto de la población, y que en contextos de conflicto armado, suelen ser inexistentes, quedar debilitados o terminar supeditados a los intereses de los actores en confrontación. En contextos de conflictividad armada, la justicia deja de existir y/o queda supeditada a los intereses de los actores armados que dominan la zona, y dado lo endémica y/o la falta capacidad de ella, termina generando incentivos para la aplicación de la justicia por mano propia o para recurrir a dichos actores. Precisamente, la restauración de la justicia tiene como razón de ser el generar mecanismos institucionales y reglados para tramitar diferentes tipos de conflictos que pueden presentarse entre la población. El postconflicto, entonces debe ser, una apuesta por construir e institucionalizar una institucionalidad judicial que permita con sus servicios de justicia que las personas tramiten sus distintas conflictividades sin recurrir a violencia alguna. 


\section{La reconstrucción de la administración pública y la activación económica}

Otro campo del que tiene que ocuparse el postconflicto es el de rehabilitar las administraciones públicas y las economías. Se entiende lo precedente si se asume que "El conflicto y la guerra destruye la infraestructura básica, interrumpe la prestación de servicios e impide rutinas asociadas con el diario vivir" (Brinkerhoff, 2007, p.6). Así, dada la destrucción que suele dejar tras de sí las confrontaciones armadas, no es raro encontrar factores e infraestructuras productivas imposibles de utilizar y seres humanos cesantes económicamente (United Nations, 2003). Igualmente, los conflictos armados traen consigo la pérdida y daño de infraestructuras, procesos y oportunidades que hacen imposible la inclusión económica de la población respecto a la generación de ingresos y de oportunidades económicas. Lo anterior, lleva a decir que en el postconflicto, deben generarse las condiciones para que los ciudadanos empiecen a suplir sus necesidades básicas, y más allá, asegurar su bienestar.

Para encararse la destrucción producida por la guerra puede implementarse una serie de estrategias. La primera está dirigida a recuperar a las poblaciones más vulnerables tales como, mujeres, niños, refugiados etc., a los cuales de manera inmediata, se les debe asegurar condiciones de ayuda humanitaria, y más allá, de diaria sobrevivencia. Para conseguirlo puede acudirse a transferencias de dinero, cupones alimentarios, precios reducidos para alimentos básicos, viviendas subvencionadas o vales para el cuidado de sí y de las familias (Naciones Unidas, 2011). La segunda estrategia, puede orientarse a lograr una reactivación económica, la cual pasa no sólo por la realización de proyectos públicos generadores de empleo y de consumo colectivo, sino también, por la promoción de iniciativas empresariales, micro-empresariales, cooperativas y solidarias. A este respecto, resultan importantes los apoyos y subsidios productivos, los fondos empresariales, los bancos de oportunidades, los procesos de capacitación, el adiestramiento y conversión de competencias productivas, entre otras.

Una tercera estrategia, estaría encaminada a la habilitación de las hasta entonces economías de guerra y la cual tiene que ver con la activación y fomento de mercados locales, regionales y nacionales. Dichos circuitos económicos al ser dañados por los ataques armados, para entrar nuevamente en funcionamiento requieren mecanismos de seguridad y de rehabilitación que permitan el flujo, circulación y concurrencia segura y permanente de bienes y agentes económicos. Para ello, en los procesos de postconflicto se 
hace indispensable una construcción o reconstrucción de las infraestructuras relacionadas con las redes de transportes, los servicios públicos, los servicios de salud, los servicios de educación, los procesos productivos y los circuitos de comercialización. A esta tarea pueden contribuir el compromiso entre el Estado y los privados, con apoyo de la ayuda internacional.

Una estrategia transversal a todas las anteriores pasa por la reconstrucción de las administraciones públicas. Estas deben posibilitar un servicio civil funcionando, sistemas básicos administrativos, control de la corrupción, adecuada infraestructura, amplios servicios de salud y educación, entre otros. Algunos autores hablan no sólo de reconstrucción sino de su reestructuración. Para esto proponen adelantar transformaciones para que a nivel nacional y local se vuelvan las administraciones eficientes, efectivas y económicas (Musoni, 2003). Para ello, se sugiere que debe llevarse a cabo la participación del gobierno, la sociedad civil y el sector privado, en tanto se precisa de ellos, para adelantar la recuperación política, social, económica y cultural de las sociedades.

Su reconstrucción es importante, porque son los aparatos administrativos los que permiten la coordinación y la conducción permanente de extensas acciones y de recursos orientados a impactar miles y hasta millones de personas afectadas por las acciones armadas. Lograr su reconstrucción, requiere el concurso de decisores y de líderes gubernamentales, de redes de organizaciones públicas, de equipos profesionales y, en general, de las energías de la administración pública.

\section{Comentarios finales}

Este capítulo aludió a las reformas de la estatalidad en escenarios de postconflicto. Se planteó, que dichas reformas deben surtirse en diversos frentes si de lo que se trata es de pasar de una sociedad con conflictos violentos a otra con conflictos democráticos. Fundamentar la consecución de un postconflicto sostenible y exitoso pasa por una transformación profunda de la arquitectura institucional del Estado en relación con la legitimidad, la seguridad, los procesos productivos y la administración pública. No se repetirá aquí las estrategias que acompañan a cada uno de dichos ejes, sino más bien, se quiere subrayar, la importancia de la complementariedad y la integralidad de unas en relación con otras. 
Aunque los cambios ligados a las constituciones políticas, la participación en instituciones políticas, el régimen electoral etc. son fundamentales en los procesos de postconflicto, ellos no son suficientes. Aunque cruciales tales estrategias encaminadas a fortalecer la legitimidad, las mismas resultan insuficientes si no hay condiciones de seguridad que acompañen su desarrollo. En ausencia de estas, pueden presentarse amenazas o riesgos que si no son atendidas pueden llevar al fracaso de los acuerdos políticos de paz. Enfrentamientos aislados que vayan escalando en intensidad y extensión; retaliaciones selectivas contra integrantes de algunos de los bandos involucrados en la negociación; amenazas, extorsiones y abusos contra la población; procesos de justicia en manos privadas, son algunos de los riesgos que corre un proceso de paz si no se atiende a la seguridad.

Un proceso de postconflicto entonces requiere condiciones de seguridad para que en los territorios donde históricamente se ha presentado conflictividad armada, ésta se desmantele y sea sustituida por la convivencia social y política pacífica. En tal sentido, deben intervenirse los territorios y las poblaciones para que las actividades y la vida de las personas no sigan estando sujetas a amenazas, intimidación o eliminación por ninguna de las antiguas fuerzas armadas ilegales o legales. Por ello, los procesos de paz conducentes al postconflicto requieren ocuparse de diversos frentes, que aunque en este capítulo ya se detallaron, aquí se mencionarán de forma concisa. Estas son:

- Desarmar, desmovilizar y reintegrar integralmente a los excombatientes.

- Generar condiciones de seguridad a los excombatientes para que den su paso a la vida civil.

- Asegurar el control de los territorios antes controlados por actores armados, subversivos y/o ilegales.

- Depurar y controlar la fuerza pública oficial para que en adelante ejerzan su autoridad de manera democrática conforme a la constitución y las leyes, y bajo el control y escrutinio de la sociedad civil.

- Proveer, fortalecer y recuperar los servicios de justicia en los territorios que presentaban conflictividades armadas y hacen tránsito al postconflicto.

Aun consiguiendo la estrategia de la instauración de la seguridad que debe acompañar a la de legitimidad, es poco lo que se avanzará si a su vez no se reconstruyen sus procesos productivos y comerciales. El axioma del que 
debe partirse, es que la guerra arruina las economías legales al turno que incentiva las ilegales. De forma tal, que no reconstruir las primeras al tiempo que desactivar las segundas, es correr el riesgo de que permanezcan y surjan los incentivos para que desde diversos lugares y actores se quiera continuar o reactivar la guerra. De no llevarse a cabo dichas medidas, puede presentarse que actores ilegales armados quieran capitalizar y continuar con actividades tales como los cultivos ilícitos, la extorsión, el secuestro, el tráfico de armas, la minería ilegal. Sin embargo, eliminar éstas actividades, supone crear otras con las cuáles sustituirlas.

A la recuperación productiva, le debe acompañar la recuperación y reparación integral de los miles y millones de víctimas que dejan los conflictos armados. Por lo mismo, el postconflicto supone, entre otras cosas, la reparación económica y el derecho a la verdad de parte de las víctimas, al turno que, el castigo o la sanción de sus victimarios. Además, requieren medidas simbólicas de memoria histórica que impidan la repetición de actos violentos en su contra, y así mismo, que empuje al grueso de la sociedad a la comprensión de los conflictos armados para desactivarlos y evitar a futuro su repetición. Se requiere además, que el tejido social de los territorios sea reconstruido y reparado, es decir, que sea posible la construcción de una actitud generalizada de confianza, fraternidad y convivencia.

Pero si la legitimidad, la seguridad y la recuperación productiva cuentan a la hora de conseguir un postconflicto con atributos de éxito y sostenibilidad en el tiempo, también requiere la reconstrucción de sus instituciones y/o organizaciones públicas. ¿Pero... qué es reconstruirlas en escenarios de postconflicto? Esto se entiende en varios sentidos. El más claro, es que en los territorios donde se presentó el conflicto armado deben erigirse instituciones que provean los servicios públicos y sociales que suplen necesidades básicas al conjunto de la población (agua potable, saneamiento básico, salud, educación, energía, seguridad alimentaria etc.). Igualmente, reconstruir la administración pública supone que sus instituciones y/o organizaciones sean capaces de proveer los bienes públicos necesarios para el desarrollo productivo de sus sociedades (vías de acceso, lugares de acopio y comercialización de productos, puertos, redes de telecomunicación etc.).

Aun generando que las instituciones presten esos servicios y bienes públicos, también es importante que logren otros objetivos estratégicos en su reconstrucción. Se trata de desligarlas de los actores legales e ilegales que las convirtieron en instrumento para la guerra, y ponerlas más bien, al servicio 
de los ciudadanos. Bajo ese propósito, se trata de terminar con jueces y funcionarios que a cambio de dádivas permitían y legalizaban despojos y abusos contra la población; con policías y soldados pagados para perseguir opositores o proteger mercados ilícitos; con élites políticas y económicas, que capturaban administraciones locales para saquearlas y ponerlas en función de sus intereses ilegítimos.

El postconflicto es una cuadratura difícil de lograr, si no se atienden en simultánea y en articulación los diferentes frentes mencionados de legitimidad, de seguridad y de reconstrucción, y que en su momento, fueron detallados en este capítulo. Todos estos ejes implican reformas profundas de la estatalidad en sus agendas, compromisos y modos de operación de su aparataje. Se trata de una reforma a la estatalidad que no sólo elimine el conflicto armado, sino que actúe sobre sus causas, para que no vuelva a presentarse a futuro como una alternativa viable y atractiva. En ese sentido, se pretende una reforma que trabaje no sólo para que los grupos ilegales e insurgentes dejen definitivamente las armas, sino también, para que a futuro otros no se vean tentados ni tengan oportunidades para hacerlo.

Finalmente, algo que aportaron las revisiones de literatura y las reflexiones presentadas en el capítulo, es el de la prudencia y de la experticia que requiere el llevar a cabo el postconflicto. La prudencia, porque se debe contar con la sabiduría y la capacidad de decisión política para definir qué debe quedar por dentro y qué por fuera de las negociaciones y reformas. La experticia técnica, porque se debe saber calcular, proyectar y delimitar cuáles son los recursos necesarios y posibles para conseguir lo acordado y pactado, e igualmente, porque debe garantizarse que efectivamente es posible disponer o conseguir dichos recursos. Para lograr un postconflicto, aunque es fundamental, no es suficiente el júbilo y la fiesta derivada de la firma de paz. Tan importante es que los compromisos pactados sean realizados, cuestión que puede verse turbada o arruinada, si no proyectan y consiguen los recursos financieros, materiales, logísticos, humanos etc. necesarios, al igual que las estrategias para asegurar su buen uso y no dilapidación. 


\section{VII}

\section{CONCLUSIONES ${ }^{20}$}

El recorrido realizado en este texto alrededor de diferentes temas, trabajos y autores, permite afirmar que al momento actual existe entre las ciencias sociales una disciplina con importantes preocupaciones, problemas y desafios: la Administración Pública. Esta, desde siglos atrás ha venido haciendo aportes a cómo pensar y proyectar la estructuración, cohesión y conducción de las sociedades por efecto de la acción administrativa. El estudio de la Administración Pública aunque verse sobre nociones y realidades que pueden llegar a aparecer como especializadas, técnicas y abstractas, lo cierto es, que terminan por definir cuestiones fundamentales para el destino de las personas a nivel individual y colectivo.

De las creaciones administrativas que se ocupan de estudiar la Administración Pública, termina por depender el reconocimiento y satisfacción de las necesidades de la población; la eficaz, oportuna y equitativa resolución a sus requerimientos y demandas; su acceso a servicios públicos (agua potable, alcantarillado, energía, gas, etc.); su disfrute de servicios sociales (salud, educación, empleo, protección a la infancia); su disponibilidad de infraestructuras viales, comunicacionales y urbanísticos; el reconocimiento y garantía de sus derechos e identidades colectivas; el desarrollo productivo y social de sus territorios.

Por todo aquello que está en juego, ocuparse de la administración pública como institución y saber es un asunto estratégico que debe tener una importancia central en las agendas públicas de ciudadanos, gobernantes, especialistas y líderes públicos. El escenario ideal del desarrollo de esta disciplina es contar con el apoyo de otras ciencias como la política, la sociología, la antropología, y el derecho, para que aprovechando sus utillajes

20 Estas conclusiones compila de manera textual las conclusiones parciales de cada uno de los capítulos precedentes. Pretende ser de utilidad a quienes por razones diversas no leyeron la totalidad de los mismos y/o quieran saber sus planteamientos principales. Igualmente, quiere ser de guía a quienes quieran hacerse a una idea global del texto antes de profundizar en cada una de sus partes. A quienes trabajaron en detalle cada uno de los capitulos, puede sobrar su lectura. 
interpretativos, conceptuales y metodológicos, pueda lograr explicar y proyectar con integralidad sus objetos de estudio. Sin embargo, debe serle claro que otras disciplinas sociales aunque contribuyan, no pueden reemplazarla en el estudio de sus particulares objetos, preocupaciones y problemas. Como se pudo ver en el recorrido realizado en el Capítulo I, otra fue la época, ya superada, en donde se consideraba que ella podía reducirse a espera y alimentarse de los desarrollos de otras disciplinas.

\section{A propósito de la democratización de la administración pública...}

Es cada vez más clara, expresa y directa la articulación que se busca entre la realidad institucional de la administración pública y el de la democracia. Históricamente ésta última se instituyó cómo aquel régimen y sistema que sustentó su legitimidad en que el poder del Estado debía servir y estar en función de los ciudadanos. Con ella, se erigió la posibilidad de que el poder público ya no estuviera en función del príncipe, el rey o la a nobleza, sino también, que estuviera en función de proporciones cada vez más amplias de la población. Con la democracia los pobladores dejaron de ser súbditos para convertirse en ciudadanos, cuestión que en adelante, los convirtió en titulares del poder político del Estado. El arreglo con que se lograría instituir la democracia a lo largo del siglo XIX y primera mitad del XX, sería la democracia representativa mediante la elección de representantes y la delegación de su titularidad política en ellos. Para lograrlo, se instauró, entre otros, el voto popular, los cargos de elección popular, los sistemas electorales, los partidos políticos y los derechos de diferente tipo como los referidos a la libre asociación y a la libre opinión.

No obstante, en la última mitad del siglo XX y las primeras décadas del siglo XXI se exige que la democracia vaya más allá de permitirles a los ciudadanos de elegir mediante voto popular a unos representantes. Por ese camino, se presiona para que el Estado, su gobierno y su administración se abran a la participación ciudadana en relación con incidir en las decisiones del Estado y tener control de los procesos políticos-administrativos que se desarrollan a su interior.Ya no era suficiente que la democracia se limitara a un asunto de votaciones y representantes políticos, sino que debía de ampliarse para que se posicionara al interior del mundo de la administración pública. Se pide que ella se haga realidad en sus organizaciones públicas, sus políticas públicas, sus procesos de gestión y sus relaciones Estado y sociedad, entre otros. 
Por ese camino se busca democratizar sus estructuras y gestión mediante la apuesta de que el ciudadano y sus derechos aparezcan como el centro y referente de su accionar. Bajo dicha apuesta, ya no es suficiente que los agentes de la administración pública legitimen su actuación en principios como la legalidad, la eficacia o la eficiencia, sino también, en otros tales como el servicio al ciudadano, la garantía de derechos, la participación ciudadana, la responsabilidad y la rendición de cuentas. Como se evidenció a lo largo del capítulo II, un principio interesante que empezó a acuñarse en América Latina para democratizar la administración pública fue el derecho a la "participación en la gestión pública".

Dicho derecho, expresa una apuesta por abrir y situar a la administración pública en función de la ciudadanía, abriéndola a su influencia y control. Bajo este, se empezó a promover el derecho que deben tener los ciudadanos para participar activamente en la construcción de las políticas públicas en sus distintas fases, al igual que, en los diferentes procesos institucionales de la administración pública. El propósito de dicha participación es que diferentes grupos de ciudadanos puedan contar con canales y recursos para garantizar y materializar sus derechos.

Además, la democratización de la administración pública pretendía que el poder del Estado se asegurara de ser público y dejara de ser privado. Como lo mencionó Nuria Cunill, se trató de que la ciudadanía contrabalanceara el poder de las élites, los políticos y las burocracias que habían capturado el poder y los recursos del Estado. Con el poder ciudadano se abría un camino que permitía combatir o solucionar distintos males que vivían las instituciones y sus encargados. Con la apertura a los ciudadanos por parte de las administraciones públicas se esperaba corregir otras falencias que se empezaban a divisar entre el personal administrativo, entre las cuales se contaba, la manera estrecha con que veían el mundo y el relegamiento que hacían de los intereses de la población.

El recorrido realizado en el capítulo II permitió evidenciar también cómo el poder de la ciudadanía al operar al interior de la administración pública puede permitirle logar su vocación pública y democrática. Un elemento fundamental es que ella debe propiciarse no solo en una $u$ otra institución sino en el conjunto del Estado, lo anterior, bajo el tópico de la Reforma del Estado. Es así que, sus promotores situados en determinado contextos históricos de transformación del Estado en América Latina, apuestan a que si ella ha de realizarse debe apuntar a garantizar no sólo el crecimiento 
económico o la eficiencia, sino ante todo, la democracia y estar al servicio de la ciudadanía. Por este camino, la reforma aparece inspirada por otros valores tales como la igualdad, la inclusión y la participación, entre otros. Más elementos se suman a ellos, tales como lo son la integridad, la transparencia y la responsabilidad, al igual que, la cooperación, el diálogo y la concertación.

Que la democracia ahora deba cultivarse y crecer al interior de las administraciones públicas, o igualmente, que el poder ciudadano deba asumirse como una nueva variable y principio de la gestión pública, no es una cuestión fácil de realizar y asumir en el corto plazo. Debe avanzarse, no sólo en crear diseños institucionales donde se abran espacios para la participación activa de la ciudadanía, la rendición de cuentas y la transparencia, sino también, en crear culturas administrativas que asimilen este otro paradigma. Un desafio es cambiar las mentalidades de dirigencias, directivas y funcionarios educados bajo concepciones elitistas o burocráticas, que en no pocos casos, los lleva a desconfiar, subestimar e irrespetar a los ciudadanos a nivel individual y colectivo.

Dicho aprendizaje no es fácil para los responsables y operadores del Estado y la administración pública. Ellos deben de tramitar conflictos y lidiar con racionalidades de distinta naturaleza que les exigen cosas distintas que no siempre fáciles o posibles de conciliar. Como ya se mencionaba en uno de los apartados, los administradores de lo público deben resolver dilemas del siguiente tipo: mientras la racionalidad democrática les exige que promuevan la igualdad, la de corte administrativa les empuja a respetar la jerarquía;mientras la racionalidad democrática le impulsa a fomentar la participación colectiva en la toma de decisiones, la de tipo administrativo les demanda limitarse al concepto propio y al de los expertos; mientras la racionalidad democrática les solicita que promuevan la equidad, la administrativa les exige basarse en el criterio de la eficiencia preocupada por los costos y los resultados.

\section{A propósito de las TIC en el sector público...}

En el último cuarto de siglo XX y lo corrido del XXI, las Tecnologías Informáticas y Comunicativas (TIC) han ganado terreno no sólo en la vida de las personas sino en el sector público. Lo han hecho, entre otras, porque han contribuido a generar capacidades de distinta naturaleza al interior de la administración pública y a las relaciones que ella tiene con la sociedad. Las TIC pueden aportar a abrir las puertas a canales más amplios y versátiles entre los encargados del sector público y los ciudadanos; los directivos y 
sus empleados; los responsables del gobierno y los proveedores; los niveles nacionales y locales; los distintos sectores administrativos.

Otros son los aportes que las TIC pueden hacer a las administraciones públicas en relación con sus organizaciones, procesos y políticas públicas. Lo anterior, si se tiene en cuenta:

- Las capacidades exponenciales que aportan al almacenamiento, recuperación y análisis de información.

- Las facilidades que brindan sus redes para propiciar el trabajo colaborativo al conectar en simultánea infinidad de puestos de trabajo, puntos de atención o entidades.

- Los soportes que proponen para conectar en tiempo real de manera virtual a territorios, poblaciones e instituciones distantes en lo que respecta a su localización geográfica.

- Las posibilidades que abren para acercar el Estado a los ciudadanos.

- Las capacidades que habilitan para la prestación online de servicios y bienes a los diferentes públicos ciudadanos y privados con que interactúa.

Es claro hoy que gracias a las TIC el acopio, archivo y recuperación de miles y millones de datos, ya no supone ingentes ejércitos de personal o inmensas locaciones para su acopio, o así mismo, meses para su ubicación y procesamiento. Por efecto de ellas, se requiere más bien, de reducidos equipos de personal, de plataformas de almacenamiento que ocupan poco espacio y de recuperaciones de información que requieren minutos, o acaso, segundos. Otras facilitaciones han abierto las TIC a la vida de los ciudadanos y de los funcionarios públicos. Trámites que antaño les implicaban demoras los ciudadanos tales como el pago de servicios públicos, de impuestos, de obtención de licencias etc., gracias a ellas, hoy pueden hacerlas con rapidez y comodidad. Igualmente, para quien realizar trámites ante el Estado le suponía grandes desplazamientos, con las TIC, se le abrió las posibilidades para que pudiera realizarlas sin moverse de su casa o de su lugar del trabajo.

Para los funcionarios públicos, y más en general para la administración pública, las TIC abren la posibilidad de llevar control de los recursos del Estado. Les permite llevar un registro minucioso de los recursos financieros y activos con que cuenta y cómo los mismos se van ejecutando. Así mismo, 
les facilita identificar y focalizar con amplitud y rapidez los miles y millones de aportes que realizan los ciudadanos a las arcas del Estado, pero también, los amplios desembolsos dirigidos a sus beneficiaros. Igualmente, las TIC amplían las posibilidades a llevar un control de las acciones que cada una de las entidades y funcionarios realizan, para establecer, si las mismas están generando y agregando con ellas valor público. En fin, las TIC permiten hacer más integrados, rápidos y exhaustivos y procesos de gestión.

Las TIC no son la panacea. Su promoción puede estar cargada de promesas que no posibles de cumplir, y además, inducir al fetichismo tecnológico que lleva a creer que ellas como objetos inertes son por sí mismas la solución a los problemas. Las tecnologías aunque sean las más sofisticadas, pueden no generar ningún cambio deseado, si ellas no están articuladas a transformaciones profundas en los comportamientos y relaciones de los agentes que interactúan con ellas. Y esto conecta con algo ilustrado en la exposición realizada en el capítulo III, donde se evidenciaba que es importante no sólo contar con soportes, plataformas y equipos tecnológicos de avanzada, sino también, en poder hacer uso de ellas y saber maximizar sus prestaciones o utilidades. Las sociedades y las administraciones deben educar a sus agentes para que puedan aprovecharlas y maximizar sus utilidades.

En ese sentido, se argumenta en relación con la importancia que tiene hoy por hoy que las universidades avancen en la formación de sus graduandos en saberes y competencias tecnológicas e informáticas. Más desafiante, pero no menos importante, es el objetivo de que provean procesos de formación donde los profesionales al servicio del sector público aprendan a pensar tecnológicamente, que los lleve a asumir que, en toda solución de un problema administrativo, las TIC pueden constituirse en una variable clave. Sin embargo, esto supone conocerlas a fondo para identificar sus prestaciones, funciones, utilidades y alcances, pero también, en sus especificidades y compatibilidades con otras tecnologías.

Un elemento importante que se presenta hoy para los encargados y responsables del sector público, es saber qué tecnologías, equipos y plataformas se encuentran disponibles en el mercado y se hacen adaptables a sus necesidades, e igualmente, establecer cuál es la versatilidad de las mismas para adaptarse a otras necesidades existentes y venideras. También se trata de saber cuáles son los entornos tecnológicos del sector público, de forma tal que, las tecnologías que se vayan a adoptar en una organización o sector puedan generar prestaciones a otras instituciones, e igualmente, 
pueda conectarse y aprovechar los de otras. Todo lo anterior, porque no debe olvidarse que el sector público es un circuito integrado por muchas organizaciones dependientes entre sí que colaborativamente deben cumplir unos propósitos comunes.

\section{A propósito de la innovación en el sector público...}

Una característica de la Administración Pública como disciplina es que se le exige no sólo que explique situaciones o fenómenos dados, sino también que, acorde a propósitos de tipo político, técnico y/o social proponga intervenciones para transformarlos. Es en el marco de conseguir ese objetivo, donde en las últimas décadas emerge un campo de estudio relacionados con la innovación en el sector público. Cómo se vio en el capítulo IV, con la innovación se busca generar nuevos cursos de acción y soluciones a situaciones problemáticas que enfrentaban los responsables y encargados del sector público. Cuatro estrategias centrales entraron a soportar la edificación de este campo de estudio. La primera, fue asumir como valiosa las experiencias y conocimientos acumulados de los propios agentes e instituciones involucradas en el problema, al tiempo que, de sus soluciones encontradas. La segunda, fue desarrollar un interés académico por recogerlas y explicarlas en relación con cómo habían sido logradas para teorizarlas y hacerlas replicables a otras situaciones o contextos. La tercera, fue la concertación entre instituciones gubernamentales, académicas y del sector privado para fortalecer instituciones públicas y prescribir modelos de acción pública. La cuarta, fue la realización de concursos para recolectar experiencias de múltiples contextos, pero también, para darlas a conocer a través de publicaciones y foros.

Importante advertir, la innovación aunque supone la puesta en juego de la imaginación para crear nuevas respuestas a problemas administrativos, va más allá. Supone la generación de unas condiciones institucionales para que sea llevada a cabo como un asunto serio y riguroso. Por emocionante que pueda sonar el término, no se trata con ella de una cuestión donde se pueda jugar al ensayo y al error ya que los fracasos en la administración pública siempre implican grandes costos en términos monetarios, humanos y sociales. Por lo anterior, adelantar la innovación de forma responsable, supone la creación de centros de investigación y de observatorios, al igual que de equipos académicos y sistemas de información que permitan recoger y rastrear a profundidad experiencias que se vuelvan teorías o modelos de 
acción con la fundamentación y validez necesaria como para ser replicados con certidumbre y confianza.

De advertir es también que, la innovación trae un mensaje implícito que la puede llevar a ser vista como una oportunidad para enriquecer el estudio de la Administración Pública como disciplina, pero también, como una amenaza que puede llevar a deteriorarla. Se constituye en una oportunidad al abrir los espacios académicos y de gestión para incentivar la búsqueda de soluciones a problemas administrativos o de gobierno de vieja data, al turno que, por generar otras formas de pensar y proyectar el cambio institucional. Sin embargo, a la par que abre dichas oportunidades, puede llevar a banalizar o nublar la comprensión del cambio organizacional e institucional por llegar a asumir que para llevarlo a cabo es suficiente la buena voluntad, el entusiasmo y la imaginación de las personas ${ }^{21}$.

El entusiasmo por la innovación puede generar saltos al vacío donde la observación y la explicación con atributos científicos pueden salir sobrando. Así mismo, puede llevar a un voluntarismo temerario de creer que se pueden cambiar las cosas sólo porque así se desea, o igualmente, que el cambio a generar es de por sí positivo sin contemplar si podría empeorar las cosas al traer mayores costos y/o consecuencias indeseables. Esto lleva a invocar sobre la necesidad de la investigación científica en este campo que lleve a sus agentes, primero, a que se esfuercen por comprender los mecanismos explicativos que dan cuenta del funcionamiento de la innovación en el sector público, y segundo, a que proyecten soluciones que sean replicables en otros contextos.

Otro de los riesgos en que puede traer la innovación como potencial campo de estudio de la Administración Pública como disciplina es que ésta la empuje solamente a ocuparse del estudio y la solución de los pequeños problemas, y con ello, bloquee la preocupación, mirada y discusión de los cambios estructurales que deben efectuarse en el mundo institucional del sector público. Sin embargo, como también se mostró en el capítulo IV, algunos autores conscientes de dicho riesgo la estudian y conceptualizan bajo el lente de entenderla como reforma global y administrativa del Estado. En este marco, las respuestas a problemáticas transversales al Estado dieron

21 Y no en su lugar, cambios profundos, por ejemplo, en las estructuras, las líneas de autoridad, las relaciones de poder, la división del trabajo, la focalización de beneficiarios y aportantes, y el flujo de recursos de las organizaciones. Cuestiones éstas últimas que, sólo pueden ser identificadas en observaciones y análisis sistemáticos rigurosos y prolongados en el tiempo. 
lugar a estrategias y herramientas administrativas novedosas, pero también, controversiales. Entre las mismas, estuvieron los presupuestos por resultados, las cartas de servicio al ciudadano, la prestación de bienes y servicios por medios virtuales, las rendiciones de cuentas y el gobierno electrónico.

Las áreas temáticas a nivel micro donde se persiguieron soluciones novedosas fueron las referidas a la prevención y combate de la corrupción; la responsabilidad en el servicio público; la transparencia y la rendición de cuentas; la mejora en los servicios de educación, salud, justicia y seguridad; la promoción de la participación en la hechura de las políticas públicas; la aplicación de las tecnologías en el gobierno; y la promoción de género al interior del sector público.

\section{A propósito de la diversidad y la multiculturalidad en la administración pública...}

En el capítulo V, se pudo evidenciar que hoy resulta fundamental que los gobiernos y las administraciones públicas permitan y promuevan la inclusión de los diversos grupos e identidades que integran la sociedad. Se trata de generar instituciones que tienen el compromiso con el igual acceso al Estado de los distintos grupos poblacionales que integran una sociedad. Igualmente, se entiende que se hace necesario el reconocimiento e influencia de la población con diversidad en la formulación e implementación de las políticas públicas. Al Estado y las administraciones públicas, les resulta fundamental remover las barreras formales e informales sustentadas en patrones, prácticas y reglas excluyentes ligadas a la raza, al género, el origen, la religión, la lengua etc. Bajo dicha búsqueda los gobiernos y administraciones deben evitar, por ejemplo, que a las mujeres por su condición sexual se les impida acceder a cargos públicos o ascender en ellos, o igualmente, se les genere menores reconocimientos salariales a los obtenidos por hombres.

En países, se constata un crecimiento del número de grupos poblacionales provenientes de distintas naciones, etnias y culturas, que han obligado a las administraciones a asumir dicha variables como significativas para su organización. Una muestra es que, en las últimas décadas en los Estados Unidos una proporción significativa del personal del sector público está integrado por personas con culturas diversas, con edades disímiles, con preferencias de género distintas, con capacidades fisicas o mentales desemejantes etc. Todo lo anterior, les ha llevado a sus administraciones y gobiernos a tener que integrar dicha multiplicidad a sus diseños, procesos y organizaciones. 
La diversidad y multiculturalidad que hace presencia en el mundo de la administración pública, pero más en general, en las sociedades contemporáneas, ha sido fuente de conflicto y de oportunidad. En el capítulo V se mostró cómo en las organizaciones públicas se presentan conflictos por la presencia de prácticas y pautas discriminatorias que terminan por afectar no sólo su clima laboral, sino también, los servicios y bienes que prestan a los ciudadanos. La conclusión a lo que lleva todo lo anterior, es que los diseños organizacionales y de personal deben asumir como unas de sus variables importantes de su accionar la diversidad y la multiculturalidad. No sólo debe reconocerse que hace presencia en ellas diferentes marcas identitarias, sino sobre todo, que se debe agenciar como propósito explícito de sus actividades y procesos administrativos y de gestión.

Tendencias del pensamiento y del accionar administrativo han visto la diversidad y la multiculturalidad no tanto como un problema político y social, sino también, como fuente generadora de oportunidades y mejores desempeños en las organizaciones y en los servicios prestados a la sociedad. Así, divisan como el reclutamiento de trabajadores de diversas culturas o naciones pueden asegurar mejor atención, bienes y servicio a los usuarios o ciudadanos, por contar, con integrantes de diferentes culturas, naciones, géneros, edades o etnias pueden tener una relación más próxima y sensible a las necesidades y gustos de distintos grupos de la población a los que quiere llegar o impactar. Al contar con ellos, se divisa como un plus, ya que aporta puntos de vistas culturales e identitarios distintos de cómo y desde dónde ver las problemáticas y sus soluciones.

Es importante recalcar que la administración pública multicultural y diversa no va solamente hasta el punto de garantizar el acceso y la promoción igualitaria del personal o de los procesos administrativos que compone el sector público. También refiere a la generación de políticas públicas, medidas especiales y a derechos a favor de ciertos grupos y a sus integrantes. Entre estos, pueden contarse autonomías especiales para el gobierno de comunidades étnicas o culturales; educación con contenidos, estilos y narrativas donde se respete y fomente las tradiciones o costumbres de ciertos grupos; el uso, promoción y protección de otras lenguas y lenguajes que deben ser usados por instituciones. Supone esta faceta de la administración pública, el despliegue de acciones afirmativas que permitan a poblaciones tradicionalmente excluidas quedar incluidas al darse su reconocimiento y respeto de sus diferencias. 


\section{A propósito del postconflicto y la reforma de la estatalidad...}

Otro de los capítulos que integró este texto aludió a las reformas de la estatalidad en escenarios de postconflicto. Se planteó, ellas deben surtirse en diversos frentes si de lo que se trata es de pasar de una sociedad con conflictos violentos a otra con conflictos democráticos. Fundamentar la consecución de un postconflicto sostenible y exitoso pasa por una transformación profunda de la arquitectura institucional del Estado en relación con la legitimidad, la seguridad, los procesos productivos y la administración pública. No se repetirá aquí las estrategias que acompañan a cada uno de dichos ejes, sino más bien, se quiere subrayar, la importancia de la complementariedad y la integralidad de unas en relación con otras.

Aunque los cambios ligados a las constituciones políticas, la participación en instituciones políticas, el régimen electoral etc., son fundamentales en los procesos de posconflicto, ellos no son suficientes. Aunque cruciales tales estrategias encaminadas a fortalecer la legitimidad, las mismas resultan insuficientes si no hay condiciones de seguridad que acompañen su desarrollo. En ausencia de estas, pueden presentarse amenazas o riesgos que si no son atendidas pueden llevar al fracaso de los acuerdos políticos de paz. Enfrentamientos aislados que vayan escalando en intensidad y extensión; retaliaciones selectivas contra integrantes de algunos de los bandos incursos en la negociación; amenazas, extorsiones y abusos contra la población; procesos de justicia en manos privadas, son algunos de los riesgos que corre un proceso de paz si no se atiende a la seguridad.

Un proceso de postconflicto entonces requiere condiciones de seguridad para que en los territorios donde históricamente se ha presentado conflictividad armada, ésta se desmantele y sea sustituida por la convivencia social y política pacífica. En tal sentido, deben intervenirse los territorios y las poblaciones para que las actividades y la vida de las personas no sigan estando sujetas a amenazas, intimidación o eliminación por ninguna de las antiguas fuerzas armadas ilegales o legales. Por ello, los procesos de paz conducentes al postconflicto requieren ocuparse de diversos frentes, que aunque en este capítulo ya se detallaron, aquí se mencionarán de forma concisa. Estas son:

- Desarmar, desmovilizary reintegrar integralmente a los excombatientes.

- Generar condiciones de seguridad a los excombatientes para que den su paso a la vida civil. 
- Asegurar el control de los territorios antes controlados por actores armados, subversivos y/o ilegales.

- Depurar y controlar la fuerza pública oficial para que en adelante ejerzan su autoridad de manera democrática conforme a la constitución y las leyes, y bajo el control y escrutinio de la sociedad civil.

- Proveer, fortalecer y recuperar los servicios de justicia en los territorios que presentaban conflictividades armadas y hacen tránsito al postconflicto.

Aun consiguiendo la estrategia de la instauración de la seguridad que debe acompañar a la de legitimidad, es poco lo que se avanzará si a su vez no se reconstruyen sus procesos productivos y comerciales. El axioma del que debe partirse, es que la guerra arruina las economías legales al turno que incentiva las ilegales. De forma tal, que no reconstruir las primeras al tiempo que desactivar las segundas, es correr el riesgo de que permanezcan y surjan los incentivos para que desde diversos lugares y actores se quiera continuar o reactivar la guerra. De no llevarse a cabo dichas medidas, puede presentarse que actores ilegales armados quieran capitalizar y continuar con actividades tales como los cultivos ilícitos, la extorsión, el secuestro, el tráfico de armas, la minería ilegal. Sin embargo, eliminar éstas actividades, supone crear otras con las cuáles sustituirlas.

A la recuperación productiva, le debe acompañar la recuperación y reparación integral de los miles y millones de víctimas que dejan los conflictos armados. Por lo mismo, el postconflicto supone, entre otras cosas, la reparación económica y el derecho a la verdad de parte de las víctimas, al turno que, el castigo o la sanción de sus victimarios. Además, requieren medidas simbólicas de memoria histórica que impidan la repetición de actos violentos en su contra, y así mismo, que empuje al grueso de la sociedad a la comprensión de los conflictos armados para desactivarlos y evitar a futuro su repetición. Se requiere además, que el tejido social de los territorios sea reconstruido y reparado, es decir, que sea posible la construcción de una actitud generalizada de confianza, fraternidad y convivencia.

Pero si la legitimidad, la seguridad y la recuperación productiva cuentan a la hora de conseguir un postconflicto con atributos de éxito y sostenibilidad en el tiempo, también requiere la reconstrucción de sus instituciones y/o organizaciones públicas. ¿Pero... qué es reconstruirlas en escenarios 
de postconflicto? Esto se entiende en varios sentidos. El más claro, es que en los territorios donde se presentó el conflicto armado deben erigirse instituciones que provean los servicios públicos y sociales que suplen necesidades básicas al conjunto de la población (agua potable, saneamiento básico, salud, educación, energía, seguridad alimentaria etc.). Igualmente, reconstruir la administración pública supone que sus instituciones y/o organizaciones sean capaces de proveer los bienes públicos necesarios para el desarrollo productivo de sus sociedades (vías de acceso, lugares de acopio y comercialización de productos, puertos, redes de telecomunicación etc.).

Aun generando que las instituciones presten esos servicios y bienes públicos, también es importante que logren otros objetivos estratégicos en su reconstrucción. Se trata de desligarlas de los actores legales e ilegales que las convirtieron en instrumento para la guerra, y ponerlas más bien, al servicio de los ciudadanos. Bajo ese propósito, se trata de terminar con jueces y funcionarios que a cambio de dádivas permitían y legalizaban despojos y abusos contra la población; con policías y soldados pagados para perseguir opositores o proteger mercados ilícitos; con elites políticas y económicas, que capturaban administraciones locales para saquearlas y ponerlas en función de sus intereses ilegítimos.

El postconflicto es una cuadratura dificil de lograr, si no se atienden en simultánea y en articulación los diferentes frentes mencionados de legitimidad, de seguridad y de reconstrucción, y que en su momento, fueron detallados en el capítulo V. Todos estos ejes implican reformas profundas de la estatalidad en sus agendas, compromisos y modos de operación de su aparataje. Se trata de una reforma a la estatalidad que no sólo elimine el conflicto armado, sino que actúe sobre sus causas, para que no vuelva a presentarse a futuro como una alternativa viable y atractiva. En ese sentido, se pretende una reforma que trabaje no sólo para que los grupos ilegales e insurgentes dejen definitivamente las armas, sino también, para que a futuro otros no se vean tentados ni tengan oportunidades para hacerlo.

Finalmente, algo que aportaron las revisiones de literatura y las reflexiones presentadas en este capítulo $\mathrm{V}$, es el de la prudencia y de la experticia que requiere el llevarlo a cabo el postconflicto. La prudencia, porque se debe contar con la sabiduría y la capacidad de decisión política para definir qué debe quedar por dentro y qué por fuera de las negociaciones y reformas. La experticia técnica, porque se debe saber calcular, proyectar y delimitar cuáles son los recursos necesarios y posibles para conseguir lo acordado y 
pactado, e igualmente, porque debe garantizarse que efectivamente es posible disponer o conseguir dichos recursos. Para lograr un postconflicto, aunque es fundamental, no es suficiente el júbilo y la fiesta derivada de la firma de paz.Tan importante es que los compromisos pactados sean realizados, cuestión que puede verse turbada o arruinada, si no proyectan y consiguen los recursos financieros, materiales, logísticos, humanos etc., necesarios para conseguirlo, al igual que las estrategias para asegurar su buen uso y no dilapidación. 


\section{VIII}

\section{BIBLIOGRAFÍA}

Acemoglu, D. and Robinson, J. (2006). Economic Origins of Dictatorship and Democracy. Cambridge, U.K: Cambridge University Press.

Arnold, K. (2002). Homelessness, Citizenship and Identity. The Uncanniness of Late Modernity. New York, U.S: State University Press,

Ball, N. (2007). Democratic Governance and the Security Sector in ConflictAffected Countries. En: D. Brinkerhoff (Ed.) Governance in PostConflict Societies. Rebuilding Fragile States.London, U.K; Routledge.

Banco Mundial. (2007). Qué es y cómo se hace el Presupuesto Participativo. 27 respuestas a Preguntas Frecuentes sobre Presupuestos Participativos Municipales. Quito, Ecuador: Banco Mundial, UN Habitat.

Bozeman, B. (2003). Technology Transfer and Public Policy: A Review of Research and Theory. Georgia: School of Public Policy, Research Polici Review. pp. 627-655.

Behn, R. (2008) The Adoption of Innovation: The Challenge of Learning to Adapt Tacit Knowledge. En: B. Safford (Ed.) Innovations in Government. Washington, U.S: Harvard University, Ash Institute for Democratic Governance and Innovation, Brookings Institution Press.

Belman, A. and Lerner, H. (2007). Constitutional Design, Identity, and Legitimacy in Post -Conflict Reconstruction. En: D. Brinkerhoff (Ed.) Governance in Post-Conflict Societies. Rebuilding Fragile States. London, U.K; Routledge.

Bjornlund, E. and Cowan, G. (2007) Election Systems and Political Parties in Post-conflict and Fragile State. En: D. Brinkerhoff (Ed.) Governance in Post-Conflict Societies. Rebuilding Fragile States. London, U.K; Routledge. 
Blue, W. (2003). Increased Diversity in the Workforce. Opportunities for Research In Public and Nonprofits Organization. En R. Mitchell (Ed,). Diversity and Public Administration:Theory, Issues, and Perspectives. New York, U.S. M.E Sharpe.

Bonnin, Ch (1834). Compendio de los Principios de Administración. Madrid, España: Imprenta de Don José Palacios.

Borins, S (2008). Introduction. En: B. Safford (Ed.). Innovations in Government. Washington, U.S: Harvard University, Ash Institute for Democratic Governance and Innovation, Brookings Institution Press.

Bresser, L. y Otros. (1998). Una Nueva Gestión Pública para América Latina. CLAD.

Bresser, L. (1998). Entre el Estado y el Mercado: lo Público no Estatal. En: L. Bresser (Ed.) Lo Público No Estatal. Buenos Aires, Argentina: CLAD.

Bresser, L. (2001). Reforma de la Nueva Gestión Pública: Ahora en la Agenda de América Latina, sin embargo...En: Revista International Journal of Political Studies. No 3,

Brinkerhoff, D. (2007). Governance in Post-Conflict Societies. Rebuilding Fragile States. London, U.K; Routledge.

Brown, M (2005). Bridging the Gap Between Information Technology Needs in the Public Sector and in Public Administration Graduate Education En: D.Garzón and C.Shea (Ed). Handbook of Public Information Systems Second Edition. New York, U.S:Taylor y Francis Groups.

Caiden, G. (2009). Building Blocks toward a Theory of Public Administration. En: A.Farazmand (Ed,). Bureaucracy and Administration. Florida, U.S: CRC Press Taylor \& Francis Group.

Callahan, K. (2007). Elements of Effective Governance. Measurement, Accountability and Participation. New York. Taylor y Francis Group.

Cassese, S, and Savino, M. (2007). Accountable Governance and Administrative Reform in Europe. En: United Nations (Ed.) Public Administration and Democratic Governance: Governments Serving Citizens. New York, U.S: ONU 
Cater, A. (2009). Information Technology Governance and Service Management: Frameworks and Adaptations. New York, U.S: Information Science Reference.

Chevallier, J. y Loschack, D. (1986). Ciencia Administrativa: Teoría General de la Institución Administrativa. Tomo I. Madrid, España: INAP

CLAD (2009). Carta Iberoamericana de Participación Ciudadana en la Gestión Pública. CLAD.

Colleman, S. and Selden, F. (2001). Rethinking Diversity in Public Organizations For The $21^{\text {St }}$ Century. Moving Toward a Multicultural Model En: Revista Administration \& Society, Vol. 33. Sage Publications. 2001

Cooper, T. (2001). Handbook of Administrative Ethics. New York, U.S: Marcel Decker.

Cox, R. (2009) Ethics and Integrity Public Administration Concepts and Cases. New York, United Estates: M.E.Sharpe.

Creighton, J. (2010). The Public Participation Handbook. Making Better Decisions Through Citizen Involvement. San Francisco, U.S: Wiley Imprint.

Cunill, N. (2004). La Democratización de la Administración Pública. Los Mitos a Vencer. En: L, Bresser (Ed.). Política y Gestión Pública. Buenos Aires, Argentina: FCE, CLAD.

Cunill, N. (1997). Repensando lo público a través de la sociedad. Nuevas formas de gestión pública y representación social. Caracas, Venezuela: Nueva Sociedad.

Farazmand, A. (2009). Bureaucracy and Administration. New York. U.S: Taylor \& Francis Group.

Ferreira, M. y Spink, P (2008). Subnational Government Innovation in a Comparative Perspective: Brazil. En: B. Safford (Ed.). Innovations in Government. Washington, U.S: Harvard University, Ash Institute for Democratic Governance and Innovation, Brookings Institution Press.

Fischer, F. (2009). Democracy and Expertise. Reorienting Policy Inquiry. New York, U.S: Oxford University Press. 
Foucault, M. (2006). Seguridad, Territorio y Población. Buenos Aires, Argentina: Fondo de Cultura Económica.

Franklin,A. and Ebdon, C. (2007). Democracy, Public Participation, and Budgeting. Mutually Exclusive or Just Exhausting? En: R. Box (Ed.). Democracy and Public Administration. London, U.K: M.E.Sharpe.

Freire, M and Stren, R. (2001). The Challenge of Urban Government. Policies and Practices. Washington, U.S: The World Bank Institute.

Fukuyama, F (2005). Global Corruption. Report 2005. Transparency International.

Garnier, L. (2005). El espacio de la Política en la Gestión Pública. En: Cuaderno de Ciencias Sociales No. 139. Costa Rica, Costa Rica: FLACSO.

Garnier, L. (1997). La Reforma del Estado: Reto de la Democracia. En: Revista Reforma y Democracia No 17. CLAD.

Garson, D. (2005). Handbook of Public Information Systems. Second Edition. New York. U.S: Taylor y Francis Groups.

Garson, D. and Khosrow, M. (2008). Handbook of Research on Public Information Technology. Information Science Reference.Volume I. New York, U.S.

Naciones Unidas. (2011). Gobernanza Pública para obtener Resultados: Capacidad del Estado para aplicar Políticas de Protección Social y Reconstrucción de Países que salen de Conflictos o Desastres. ONU.

González, F. (1994). Elementos de Ciencia Administrativa. Bosquejo de un Sistema de Administración Pública para un Estado Republicano. Bogotá, Colombia: ESAP.

Goodnow, F. (1900). Política y Administración. En: Clásicos de la Administración Pública. México, México: Fondo de Cultura Económica.

Gutman, A. (1994). Introduction. En: Ch. Taylor (Ed.). Multiculturalism. Examining the Politics of Recognition. New Jersey: Princeton University Press.

Hamilton, M. (2007). Democracy and Public Service En: R. Box (Ed.). Democracy and Public Administration. London, U.K: M.E. Sharpe. 
Harris, R. (2000). La Democratización del Estado y la Gestión Pública. En:Revista Reforma y Democracia .No 18. CLAD.

Rhoda, J. and Others (2008). Key Issues in E-Government and Public Administration. En: D. Garson (Ed.) Handbook of Research on Public Information Technology. Volume I. New York, U.S: Information Science Reference.

Kamarck, E. (2003). Government Innovation around the World. Cambridge, U.S: Ash Institute for Democratic Governance and Innovation John F. Kennedy School of Government.

Kelman, S. (2008). The "Kennedy School School" of Research on Innovation in Government. En: B. Safford. (Ed.). Innovations in Government. Washington, U.S: Harvard University, Ash Institute for Democratic Governance and Innovation, Brookings Institution Press. 2008.

Kymlicka, W. (1995). Multicultural Citizenship. A Liberal Theory of Minority Rights. London, U.K: Oxford.

Liou, T. (2001). Handbook of Public Management, Practice and Reform. New York, U.S: Marcel Dekker.

Malagón, P (2004). La Ciencia de la Policía y el Derecho Administrativo. En: Revista de Estudio Socio-Jurídico. Vol.6 No.1.

Maureen, M. and Brudney, J. (2005). Interorganizational and Interdepartmental Information Systems: Sharing Among Governments. En: D. Garson. (Ed.). Handbook of Public Information Systems. Second Edition. New York. U.S: Taylor y Francis Groups.

Menzel, D. (2010). Ethics Moments in Government Cases and Controversies. Florida, U.S:Taylor \& Francis Group.

Menzel, D. (2015). The State of Public Administration: Issues, Challenges, and Opportunities. Florida, U.S: Taylor \& Francis Group. 2015.

Molina, J. (2013). Gestión Pública Democrática. Una Corriente Alternativa de Pensamiento y de Reforma Administrativa del Estado. Bogotá, Colombia: ESAP. 
Moore, M. (2006). Creando Valor Público a través de Asociaciones Público Privadas. Contenido en Revista CLAD No 34.

Musoni, P. (2003). Reconstructing Governance and Public Administration Institutions for Effective, Conflict -Sensitive Rule of Law. En: United Nations (Ed.). Reconstructing Governance and Public Administration for Peaceful, Sustainable Development. ONU.

Naciones Unidas. (2011). Gobernanza Pública para Obtener Resultados: Capacidad del Estado para Aplicar Políticas de Protección Social y Reconstrucción de Países que Salen de Conflictos o Desastres. ONU.

Naciones Unidas. (2012). Estudio de las Naciones Unidas sobre el Gobierno Electrónico. Gobierno electrónico para el pueblo. NuevaYork, U.S: Naciones Unidas.

Naciones Unidas. (2011). Gobernanza Pública para Obtener Resultados: Capacidad del Estado para Aplicar Políticas de Protección Social y Reconstrucción de Países que Salen de Conflictos o Desastres. Organización de Naciones Unidas.

Naciones Unidas. (2011). Las Tecnologías de la Información y las Comunicaciones para el Desarrollo. Informe de la Segunda Comisión. Naciones Unidas.

Nelson, B. (2003). Políticas Públicas y Administración. Una Visión General. En: Nuevo Manual de Ciencia Política. Madrid, España: Editorial Istmo.

North, Douglas y Otros. (2009). Violence and Social Orders. New York, U.S: Cambridge University Press.

Ospina, S. (2001). Managing Diversity in Civil Service: A Conceptual Framework for Public Organizations. New York, U.S: United Nations.

Otenyo, E. and Lind, N. (2006). Comparative Public Administration:The Essential Readings. Oxford, U.K: Elseiver.

Page, M. and Oldfield, Ch. (2008). Why not Teach "Diversity". En: International Journal of Public Sector Management Vol. 21 No. 4. Emerald Group Publishing Limited.

Peters, G. and Painter, M. (2010). Tradition and Public Administration. New York. U.S: Palgrave Mc Millan. 
Pinzón, C. (1847). Principios Sobre la Administración Pública. Bogotá, Colombia: Imprenta de J.A .Cualla. 1847.

Poggi, G. (1978) The Development of The Modern State. California, U.S: Stanford.

Popescu, S. and Rusko, R. Managing Diversity in Public Organizations. En: Global Business and Management Research: An International Journal.Vol. 4, No. 3 \& 4. 2012.

Quijano, A. (2000). Colonialidad del Poder, Eurocentrismo y América Latina. En: E. Lander. (Ed.) La Colonialidad del Saber: Eurocentrismo y Ciencias Sociales. Perspectivas Latinoamericanas. Buenos Aires, Argentina; Consejo Latinoamericano de Ciencias Sociales.

Rice, M. (2010). Diversity and Public Administration:Theory, Issues, and Perspectives. New York. M.E Sharpe

Rojas, E. (2010). Cities. Neighborhood Upgrading and Urban Quality of Life. Washington: Inter-American Development Bank, David Rockefeller Center for Latin American Studies, Harvard University.

Rondinelli, D. Governments Serving People: The Changing Roles of Public Administration in Democratic Governance. En: D. Rondinelli. Public Administration and Democratic Governance: Governments Serving Citizens. New York, U.S: ONU.

Sánchez, J. La Administración Pública como Ciencia: Su Objeto y Estudio. México, México: Plaza y Janes.

Santos, B. (2010). Refundación del Estado en América Latina. Perspectivas desde una Epistemología del Sur. Lima, Perú: Instituto Internacional de Derecho y Sociedad.

Scavo, C., KimY. (2005) Citizen Participation and Direct Democracy Through Computer Networking: Possibilities and Experience. En: D. Garson. Handbook of Public Information Systems Second Edition. New York, U.S: Taylor y Francis Groups.

Poole, S. y Van de Ven, A. Handbook of Organizational Change and Innovation. New York, U.S: Oxford University Press. 
Smith, G. (2010). Democratic Innovations. Designing Institutions for Citizen Participation. New York, U.S: Oxford University Press.

Styhre, A (2007). The Innovative Bureaucracy. Bureaucracy in an age of Fluidity. London, U.K: Routledge.

Taylor, Ch. (1994). The Politics of Recognition. En: Ch. Taylor (Ed.). Multiculturalism. Examining the Politics of Recognition. New Jersey, U.S: Princeton University Press, 1994.

Unesco. (2005) Guía de Gobierno Electrónico Local.Bogotá, Colombia:Convenio Unesco - Universidad Externado de Colombia. E-Gobierno.

United Nations (2011). Developing Institutional Capacities of Public Administration for the Achievement of the Millennium Development Goals in Post-Conflict and Crisis Situations: Challenges, Best Practices, and Lessons Learned in Preparedness, Prevention, and Reconstruction. Report of the Expert Group Meeting. New York, U.S: United Nations.

United Nations (2001). Good Practices and Innovations in Public Governance. United Nations Public Service Awards. Winners, 2003-2011.New York, U.S: United Nations, 2011.

United Nations. (2003). Reconstructing Governance and Public Administration for Peaceful, Sustainable Development. United Nations.

Uvalle, R. (2005). El Fortalecimiento de la Vida Democrática: La Nueva Relación de la Sociedad y el Estado. Revista Reforma y Democracia No 20. CLAD.

Vigoda, E. Public Administration An Interdisciplinary Critical Analysis. New York, U.S: Marcel Dekker.

Vocino, T. and Wilson, L. (2001) Changes and Reforms in Public Administration Education. En: K. Liou (Ed.). Handbook of Public Management Practice. Marcel Decker.

Von Justi, Juan. Elementos Generales de Policía.

Waldo, D (1990). El Estado Administrativo: Conclusión. En: Clásicos de la Administración Pública. México: Fondo de Cultura Económica.

Wilkinson Adrian and Others (2010). The Oxford Handbook of Participation in Organizations. New York, U.S: Oxford University Press. 
White, L (1990). Introducción al Estudio de la Administración Pública. En: Clásicos de la Administración Pública. México: Fondo de Cultura Económica. 1990.

Wilson, W(1990). El Estudio de la Administración En: Clásicos de la Administración Pública. México: Fondo de Cultura Económica. 1990.

World Bank. (2013). Planning, Connecting, and Financing Cities Now: Priorities for City Leaders. Washington, U.S: World Bank. 


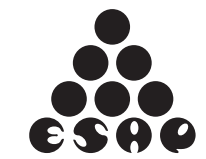

Escuela Superior de Administración Pública 
«Esta obra del doctor Jesús María Molina será muy bien recibida por motivo de su objeto y alcance. Se trata de un texto que se puede calificar de útil, temático y actual que comprende temas contemporáneos, junto con tópicos siempre presentes, entre ellos la administración pública como disciplina y campo de estudio, un ejercicio epistemológico necesario para emprender la impartición de la materia. Sin embargo, más allá, el lector encontrará la exploración a conciencia de asuntos de interés actual en el mundo y, particularmente, en América Latina».

\section{Omar Guerrero}

Ciudad de México, verano de 2017

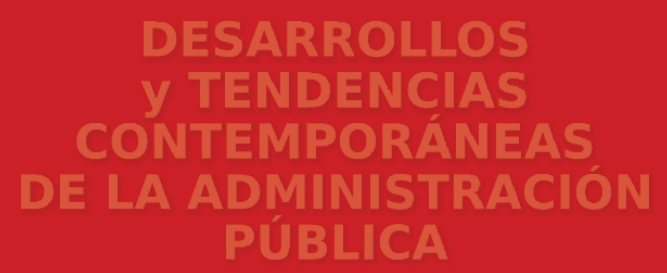

DESARROLLOS $\checkmark$ TENDENCIAS PÚBLICA 